ORNL/CDIAC- -99

Carjon pioxide, Jydrographic, and Chemical

Data oblaine puring the R/V Thomas Wasining on Cruise Tunes - in the Equalorial pacific occan. (WOCD Section P $17 \mathrm{C}$ )
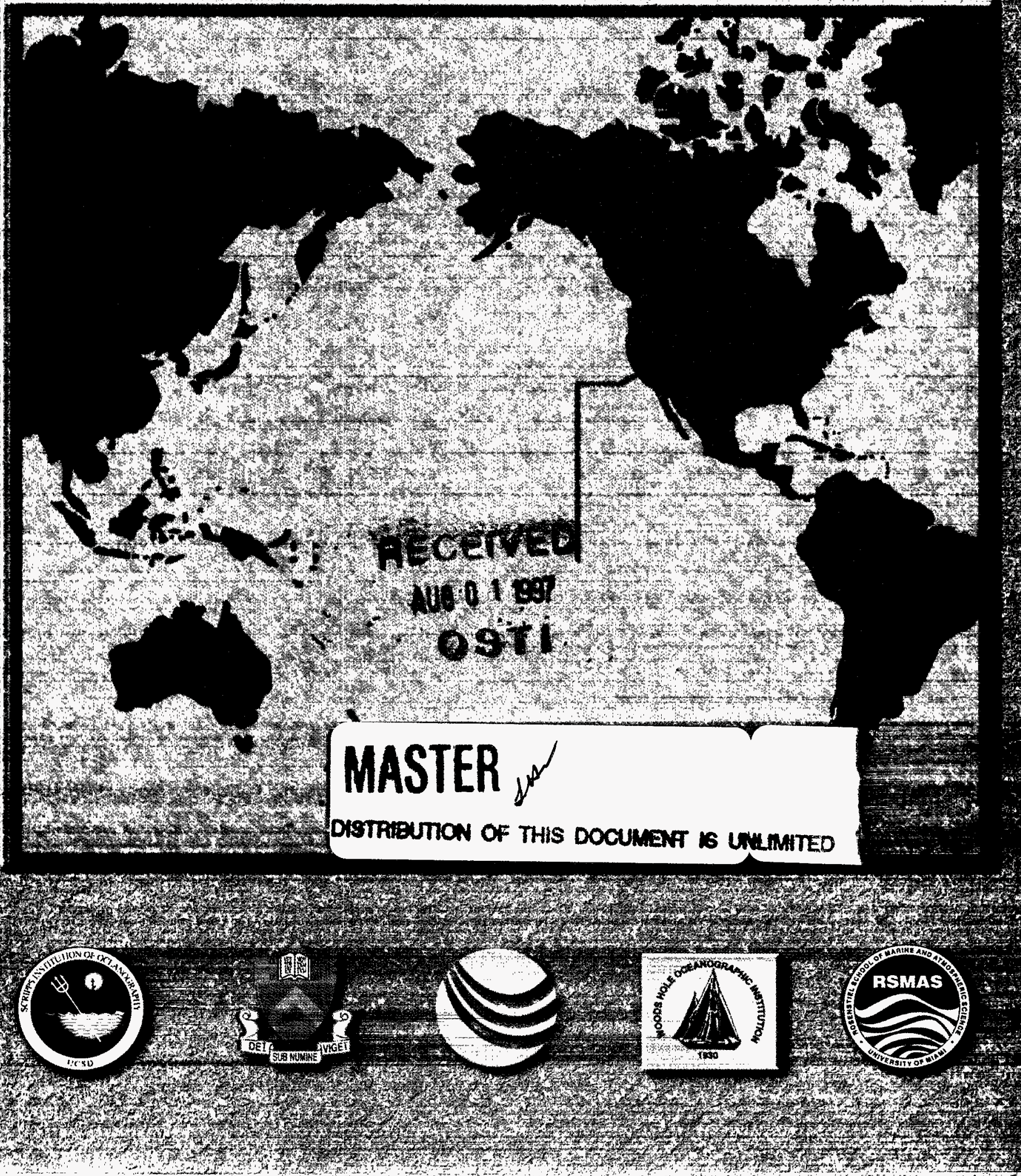
This report has been reproduced directly from the best available copy.

Available to DOE and DOE contractors from the Office of Scientific and Technical Information, P.O. Box 62, Oak Ridge, TN 37831; prices available from (423) 576-8401, FTS 626-8401.

Available to the public from the National Technical information Service, U.S. Department of Commerce, 5285 Port Royal Rd., Springfield, VA 22161.

This report was prepared as an account of work sponsored by an apency of the United States Government. Neither the United States Government nor any agency thereof, nor any of their employees, makes any warranty, express or implied, or essumes any legal liability or responsibility for the accuracy, completeness, or usefulness of any information, apparatus, product, or process disclosed, or represents that its use would not intringe privately owned rights. Reference herein to any specific commercial product, process, or service by trade name, trademark, manufacturer, or otherwise, does not necessarily constitute or imply its endorsement, recommendation, or favoring by the United States Government or any agency thereof. The views and opinions of authors expressed herein do not necessarily state or reflect those of the United States Government or any agency thereof. 


\section{DISCLAIMER}

Portions of this document may be illegible in electronic image products. Images are produced from the best available original document. 


\title{
CARBON DIOXIDE, HYDROGRAPHIC, AND CHEMICAL DATA OBTAINED DURING THE R/V THOMAS WASHINGTON CRUISE TUNES-1 IN THE EQUATORIAL PACIFIC OCEAN (WOCE SECTION P17C)
}

\author{
Contributed by \\ Catherine Goyet, ${ }^{1}$ Robert M. Key, ${ }^{2}$ Kevin F. Sullivan, ${ }^{3}$ and Mizuki Tsuchiya ${ }^{4}$ \\ ${ }^{1}$ Woods Hole Oceanographic Institution, Woods Hole, Massachusetts \\ ${ }^{2}$ Princeton University, Princeton, New Jersey \\ ${ }^{3}$ Rosensteil School of Marine and Atmospheric Sciences, University of Miami, \\ Miami, Florida
}

${ }^{4}$ Scripps Institution of Oceanography, University of California, San Diego, California

Prepared by Alexander Kozyr ${ }^{5}$

Carbon Dioxide Information Analysis Center

Oak Ridge National Laboratory

Oak Ridge, Tennessee

${ }^{5}$ Energy, Environment, and Resources Center

The University of Tennessee

Knoxville, Tennessee

Environmental Sciences Division

Publication No. 4651

Date Published: June 1997

Prepared for the

Global Change Research Program

Environmental Sciences Division

Office of Health and Environmental Research

U.S. Department of Energy

Budget Activity Numbers KP 1204000 and KP 1202030

Prepared by the

Carbon Dioxide Information Analysis Center

OAK RIDGE NATIONAL LABORATORY

Oak Ridge, Tennessee 37831-6335

managed by

LOCKHEED MARTIN ENERGY RESEARCH CORP.

for the

U.S. DEPARTMENT OF ENERGY

under contract DE-AC05-96OR22464 



\section{CONTENTS}

\section{Page}

LIST OF FIGURES $\ldots \ldots \ldots \ldots \ldots \ldots \ldots \ldots \ldots \ldots \ldots \ldots \ldots \ldots \ldots \ldots$

LIST OF TABLES $\ldots \ldots \ldots \ldots \ldots \ldots \ldots \ldots \ldots \ldots \ldots \ldots \ldots \ldots \ldots \ldots \ldots \ldots$

ABSTRACT $\ldots \ldots \ldots \ldots \ldots \ldots \ldots \ldots \ldots \ldots \ldots \ldots \ldots \ldots \ldots \ldots \ldots \ldots \ldots \ldots$

PART 1: OVERVIEW $\ldots \ldots \ldots \ldots \ldots \ldots \ldots \ldots \ldots \ldots \ldots \ldots \ldots \ldots \ldots \ldots$

1. BACKGROUND INFORMATION $\ldots \ldots \ldots \ldots \ldots \ldots \ldots \ldots \ldots \ldots \ldots$

2. DESCRIPTION OF THE EXPEDITION $\ldots \ldots \ldots \ldots \ldots \ldots \ldots \ldots \ldots \ldots \ldots$

2.1 R/V Thomas Washington Cruise TUNES-1 Information $\ldots \ldots \ldots \ldots \ldots$

2.2 Brief Cruise Summary $\ldots \ldots \ldots \ldots \ldots \ldots \ldots \ldots \ldots \ldots$

3. DESCRIPTION OF VARIABLES AND METHODS $\ldots \ldots \ldots \ldots \ldots \ldots \ldots$

3.1 Hydrographic Measurements $\ldots \ldots \ldots \ldots \ldots \ldots \ldots \ldots \ldots \ldots \ldots$

3.2 Chlorofluorocarbons Measurements $\ldots \ldots \ldots \ldots \ldots \ldots \ldots \ldots \ldots \ldots$

3.3 Radiocarbon Measurements $\ldots \ldots \ldots \ldots \ldots \ldots \ldots \ldots \ldots \ldots$

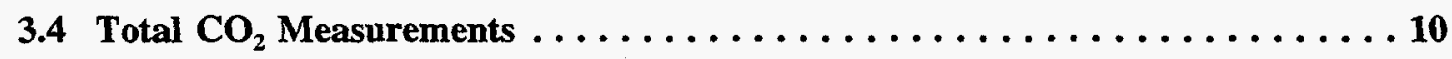

3.5 Total Alkalinity Measurements $\ldots \ldots \ldots \ldots \ldots \ldots \ldots \ldots \ldots$

3.6 Shore-Based Replicate Measurements . . . . . . . . . . . . . 11

4. DATA CHECKS AND PROCESSING PERFORMED BY CDIAC . . . . . . 24

5. HOW TO OBTAIN THE DATA AND DOCUMENTATION $\ldots \ldots \ldots \ldots \ldots$

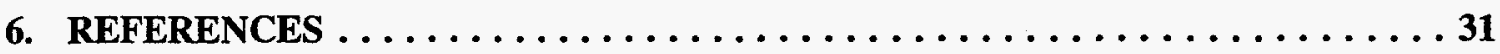

PART 2: CONTENT AND FORMAT OF DATA FILES $\ldots \ldots \ldots \ldots \ldots \ldots \ldots$

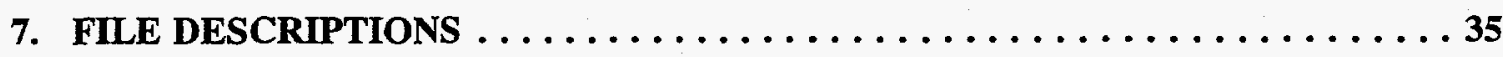




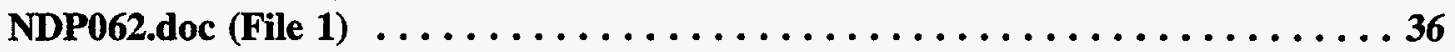

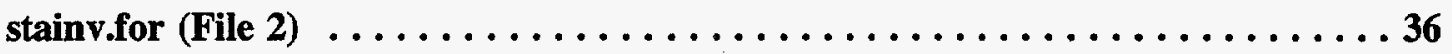

tun1dat.for (File 3) $\ldots \ldots \ldots \ldots \ldots \ldots \ldots \ldots \ldots \ldots \ldots \ldots \ldots \ldots$

tun1sta.inv (File 4) $\ldots \ldots \ldots \ldots \ldots \ldots \ldots \ldots \ldots \ldots \ldots \ldots \ldots \ldots \ldots \ldots \ldots$

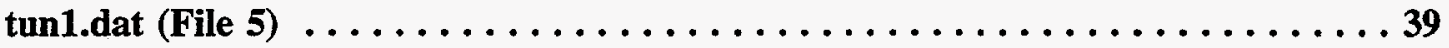

8. VERIFICATION OF DATA TRANSPORT $\ldots \ldots \ldots \ldots \ldots \ldots \ldots \ldots \ldots \ldots$

APPENDIX: STATION INVENTORY $\ldots \ldots \ldots \ldots \ldots \ldots \ldots \ldots \ldots \ldots \ldots \ldots \ldots$ 


\section{LIST OF FIGURES}

Figure

$\underline{\text { Page }}$

1 Station locations during $\mathrm{R} / \mathrm{V}$ Thomas Washington TUNES-1 Expedition $\ldots . . .4$

2 Sampling depth at all hydrographic stations occupied during $\mathrm{R} / \mathrm{V}$ Thomas

Washington TUNES-1 Expedition . . . . . . . . . . . . . 13

3 Shipboard minus shore-based $\mathrm{TCO}_{2}$ measurements vs date of surface and

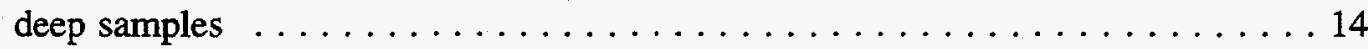

4 Nested profiles: Total carbon $(\mu \mathrm{mol} / \mathrm{kg})$ vs pressure (dbar)

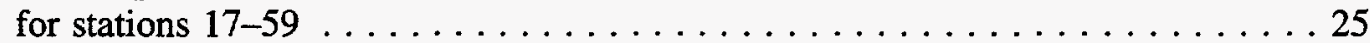

5 Nested profiles: Total carbon $(\mu \mathrm{mol} / \mathrm{kg})$ vs pressure (dbar)

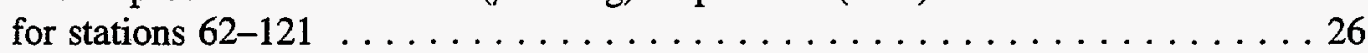

6 Nested profiles: Total alkalinity $(\mu \mathrm{mol} / \mathrm{kg})$ vs pressure (dbar)

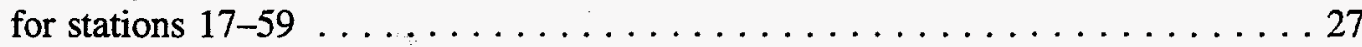

$7 \quad$ Nested profiles: Total alkalinity $(\mu \mathrm{mol} / \mathrm{kg})$ vs pressure (dbar)

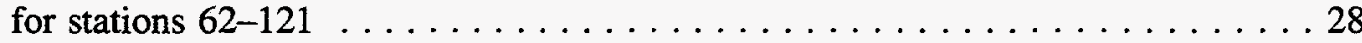

8 Property-property plots for all stations occupied during $\mathrm{R} / \mathrm{V}$ Thomas Washington TUNES-1 Expedition . . . . . . . . . . . . . . . . . . . . 29 


\section{LIST OF TABLES}

$\underline{\text { Table }}$

$\underline{\text { Page }}$

1 Summary of $\mathrm{TCO}_{2}$ replicate data collected during $\mathrm{R} / \mathrm{V}$ Thomas Washington TUNES-1 Expedition . . . . . . . . . . . . . . . . . . 15

2 Summary of TALK replicate data collected during R/V Thomas Washington TUNES-1 Expedition . . . . . . . . . . . . . . . . . . 20

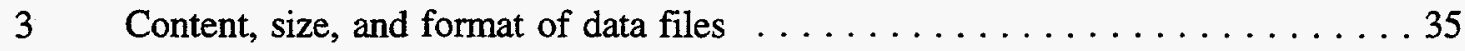

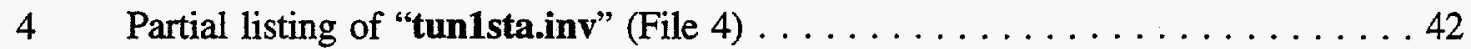

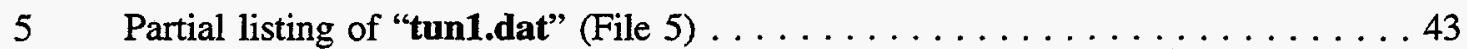

A.1 Station inventory information for the 123 sites occupied during R/V Thomas Washington TUNES-1 Expedition 



\begin{abstract}
Goyet, Catherine, Robert M. Key, Kevin F. Sullivan, and Mizuki Tsuchiya. 1997. Carbon Dioxide, Hydrographic, and Chemical Data Obtained During the R/V Thomas Washington Cruise TUNES-1 in the Equatorial Pacific Ocean (WOCE Section P17C). ORNL/CDIAC-99, NDP062. Carbon Dioxide Information Analysis Center, Oak Ridge National Laboratory, Oak Ridge, Tennessee. $61 \mathrm{pp}$.
\end{abstract}

This report discusses the procedures and methods used to obtain measurements of total carbon dioxide $\left(\mathrm{TCO}_{2}\right)$, total alkalinity (TALK), and radiocarbon $\left(\Delta^{14} \mathrm{C}\right)$, as well as hydrographic and chemical data, during the Research Vessel Thomas Washington Expedition TUNES-1 in the Equatorial Pacific Ocean (Section P17C). Conducted as part of the World Ocean Circulation Experiment (WOCE), the cruise began in San Diego, California, on May 31, 1991, and ended in Papeete, Tahiti, on July 11,1991 . WOCE Meridional Section P17C, along $135^{\circ} \mathrm{W}$ and between $\sim 5^{\circ} \mathrm{S}$ and $36^{\circ} \mathrm{N}$, was completed during the 42-day expedition. All 123 hydrographic stations (including 9 large-volume stations) were completed to the full water-column depth. Spacing between stations was 30 nautical miles, except between $3^{\circ} \mathrm{N}$ and $3^{\circ} \mathrm{S}$, where it was 10 nautical miles. At 30 stations, $\mathrm{CO}_{2}$ measurements were provided for the U.S. Department of Energy's Carbon Dioxide Program. Hydrographic and chemical measurements made along WOCE Section P17C included pressure, temperature, salinity, and oxygen (measured by conductivity, temperature, and depth sensor), as well as bottle measurements of salinity, oxygen, phosphate, nitrate, nitrite, silicate, chlorofluorocarbon (CFC)-11, CFC-12, ${ }^{14} \mathrm{C}, \mathrm{TCO}_{2}$, and TALK. In addition, potential temperatures were calculated from the measured variables.

The $\mathrm{TCO}_{2}$ concentration in 1022 seawater samples was determined by semiautomated coulometry using an improved version of the instrument earlier described by Johnson et al. (1985, 1987). The precision of these measurements was estimated to be better than $\pm 0.01 \%$. The desired accuracy was better than $4 \mu \mathrm{mol} / \mathrm{kg}$.

The TALK concentration in 323 seawater samples was determined by an automated potentiometric acid titration system that was described by Bradshaw and Brewer (1988). The precision of the measurements was estimated to be better than $0.1 \%$.

Fifty replicate samples were also collected for later shore-based reference analyses of $\mathrm{TCO}_{2}$ and TALK by vacuum extraction and manometry in the laboratory of C. D. Keeling of Scripps Institution of Oceanography.

The data set is available, free of charge, as a numeric data package (NDP) from the Carbon Dioxide Information Analysis Center. The NDP consists of two oceanographic data files; two FORTRAN 77 data-retrieval-routine files; a documentation file; and this printed report, which describes the contents and format of all files and the procedures and methods used to obtain the data.

Keywords: carbon dioxide; total alkalinity; World Ocean Circulation Experiment (WOCE); Pacific Ocean; hydrographic measurements; carbon cycle 


\section{PART 1:}

OVERVIEW 



\section{BACKGROUND INFORMATION}

The World Ocean plays a dynamic role in the Earth's climate: it captures heat from the sun, transports it, and releases it thousands of miles away. These oceanic-solar-atmospheric interactions affect winds, rainfall patterns, and temperatures on a global scale. The oceans also play a major role in global carbon-cycle processes. Carbon is unevenly distributed in the oceans because of complex circulation patterns and biogeochemical cycles. The oceans are estimated to hold 38,000 gigatons of carbon, 50 times more than that in the atmosphere and 20 times more than plants, animals, and the soil. If only $2 \%$ of the carbon stored in the oceans were released, the level of atmospheric carbon dioxide $\left(\mathrm{CO}_{2}\right)$ would double. Every year, the amount of $\mathrm{CO}_{2}$ exchanged across the sea surface is more than 15 times that produced by burning of fossil fuels, deforestation, and other human activities (Williams 1990).

To better understand the ocean's role in climate and climatic changes, several large experiments have been conducted, and others are under way. The largest oceanographic experiment ever attempted is the World Ocean Circulation Experiment (WOCE). A major component of the World Climate Research Program, WOCE brings together the expertise of scientists and technicians from more than 30 nations. In the United States, WOCE is supported by the federal government under the Global Change Research Program. The multiagency U.S. effort is led by the National Science Foundation and is supported by major contributions from the National Oceanic and Atmospheric Administration, the U.S. Department of Energy (DOE), the Office of Naval Research, and the National Aeronautics and Space Administration. Although total carbon dioxide $\left(\mathrm{TCO}_{2}\right)$ is not an official WOCE measurement, a coordinated effort, supported in the United States by DOE, is being made on WOCE cruises (through 1998) to measure the global, spatial, and temporal distributions of $\mathrm{TCO}_{2}$ and other carbon-related parameters. The goal of the $\mathrm{CO}_{2}$ survey includes estimation of the meridional transport of inorganic carbon in the Pacific Ocean in a manner analogous to the oceanic heat transport (Bryden and Hall 1980; Brewer et al. 1989; Roemmich and Wunsch 1985), evaluation of the exchange of $\mathrm{CO}_{2}$ between the atmosphere and the ocean, and preparation of a database suitable for carbon-cycle modeling, and subsequent assessment of the anthropogenic $\mathrm{CO}_{2}$ increase in the oceans. The final data set is expected to cover $\sim 23,000$ stations.

This report presents $\mathrm{CO}_{2}$-related measurements obtained during the 42-day Leg 1 of the Research Vessel (R/V) Thomas Washington TUNES Expedition (TUNES-1) along the WOCE zonal Section P17C, which is located in the equatorial part of the Pacific Ocean along the $135^{\circ} \mathrm{W}$ meridian, between $\sim 5^{\circ} \mathrm{S}$ and $36^{\circ} \mathrm{N}$ (Fig. 1).

The $\mathrm{CO}_{2}$ investigation during the TUNES-1 Expedition was supported by a grant (No. DEFGO2-90-ER60983) from DOE. 


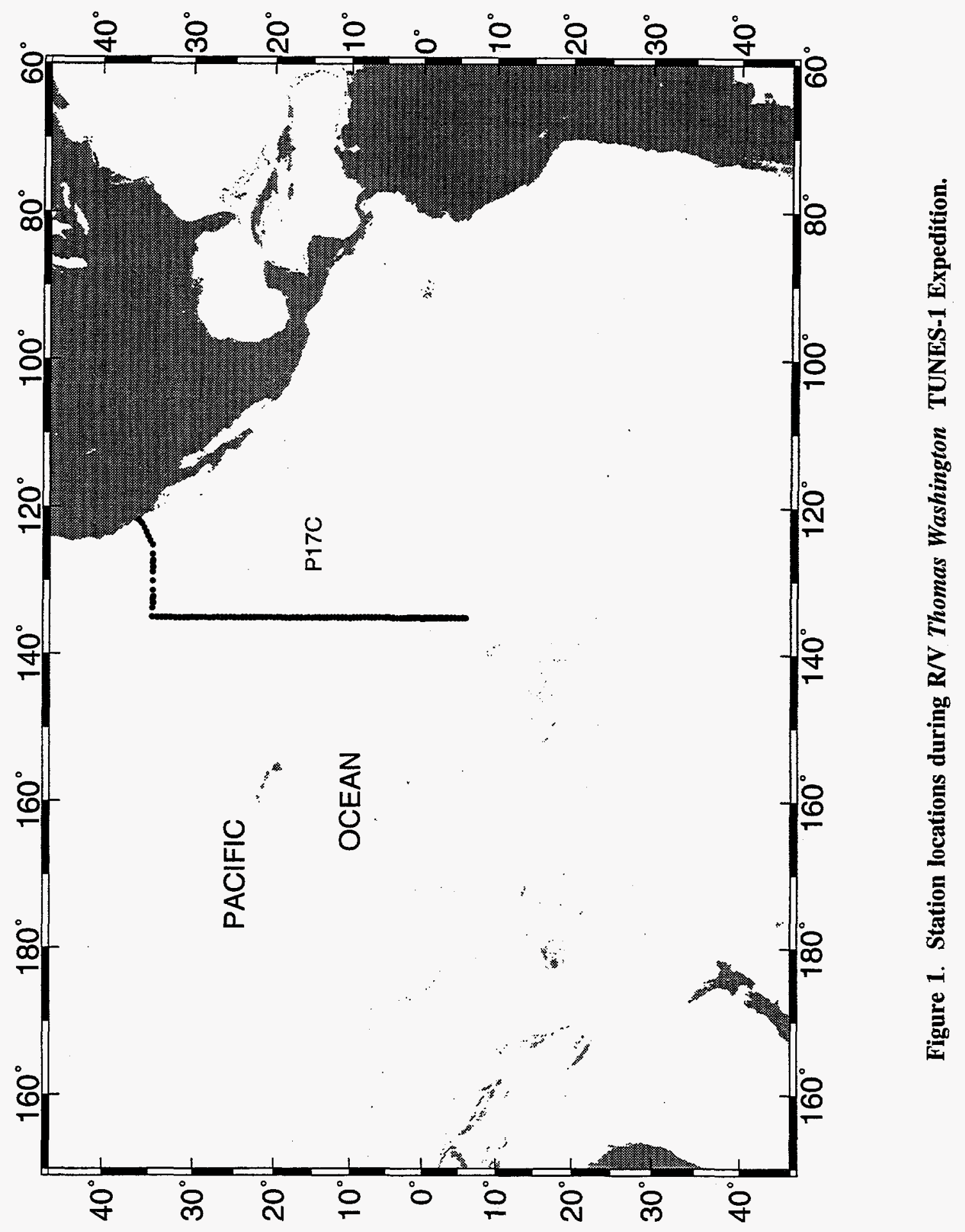




\title{
2. DESCRIPTION OF THE EXPEDITION
}

\subsection{R/V Thomas Washington Cruise TUNES-1 Information}

\author{
Ship name: Thomas Washington \\ Cruise/Leg: TUNES/1 \\ Location: Equatorial Pacific Ocean, WOCE Section P17C \\ Ports of call: $\quad$ San Diego, California, to Papeete, Tahiti. \\ Dates: \\ May 31-July 11, 1991 \\ Master: \\ T. Desjardins \\ Chief Scientist: Mizuki Tsuchiya (SIO)
}

\section{Parameters measured}

$\mathrm{CTD}^{1,2} /$ oxygen $^{2} /$ salinity $^{2} /$ nutrients $^{2}$

Nutrients (silicate, phosphate, nitrate, and nitrite) ${ }^{2}$

Underway $\mathrm{pCO}_{2}$ and nitrous oxide $\left(\mathrm{N}_{2} \mathrm{O}\right)$

Chlorofluorocarbons (CFCs) ${ }^{2}$

Helium/tritium

Helium

ALACE floats

Acoustic Doppler current profiler (ADCP)

$\mathrm{TCO}_{2}{ }^{2}$ and total alkalinity (TALK) ${ }^{2}$

$\mathrm{TCO}_{2}^{2}$ and TALK ${ }^{2}$ (shore-based analyses)

$\Delta^{14} \mathrm{C}^{2}$

Surface drifters
Institution Principal investigators

SIO

OSU

SIO

RSMAS

WHOI

UCSB

SIO

UH

WHOI

SIO

PU

SIO
L. Talley, M. Tsuchiua

L. Gordon

Ray Weiss

R. Fine

W. Jenkins

J. Lupton

R. Davis

E. Firing

C. Goyet

C. Keeling

R. Key

P. Niller

Participating Institutions

SIO

OSU

RSMAS

WHOI

UCSB

$\mathrm{UH}$

PU
Scripps Institution of Oceanography (University of California, San Diego)

Ohio State University

Rosenstiel School of Marine and Atmospheric Sciences (University of Miami)

Woods Hole Oceanographic Institution

University of California, Santa Barbara

University of Hawaii

Princeton University

${ }^{1}$ Conductivity, temperature, and depth sensor

${ }^{2}$ Measurements are reported in this data set 


\subsection{Brief Cruise Summary}

On May 31, 1991, R/ Thomas Washington departed San Diego for the first of its three consecutive TUNES series WOCE legs. Stations were numbered consecutively from the beginning of the R/V Thomas Washington work on Leg 1, TUNES-1 Expedition, starting off the coast of California. The first station (no. 1) was occupied on June 2, 1991, at $\sim 36^{\circ} 10^{\prime} \mathrm{N}$ and $121^{\circ} 44^{\prime} \mathrm{W}$. The last station (no. 123) of the TUNES-1 Expedition was occupied on July 7, 1991, at $\sim 5^{\circ} 58^{\prime} \mathrm{S}$ and $135^{\circ} 00^{\prime} \mathrm{W}$. On July $11,1991, \mathrm{R} / \mathrm{N}$ Thomas Washington arrived in Papeete, Tahiti.

During the 42-day expedition, 123 hydrographic stations (including 9 large-volume stations) were completed. All stations were sampled to the bottom and consisted of a rosette/CTD cast. Basic station spacing was 30 nautical miles, closing to 10 nautical miles between $3^{\circ} \mathrm{S}$ and $3^{\circ} \mathrm{N}$. Sampling was performed primarily with a 36-place double-ring rosette of $10-\mathrm{L}$ bottles and mounted CTD and transmissometer. CTD data consisted of pressure, temperature, conductivity, oxygen, and transmissometry. Water samples were collected for analyses of salt, oxygen, silicate, phosphate, nitrate, and nitrite at all stations and for CFC-11, CFC-12, helium, tritium, ${ }^{14} \mathrm{C}, \mathrm{TCO}_{2}$, and TALK at selected stations. Underway measurements included ADCP, surface temperature, and surface water and atmospheric $\mathrm{pCO}_{2}$ and $\mathrm{N}_{2} \mathrm{O}$.

\section{DESCRIPTION OF VARIABLES AND METHODS}

The data file tun1.dat (see Sect. 7 "File Descriptions" in Part 2) in this numeric data package (NDP) contains the following variables: station number, cast number, sample number, bottle number, CTD pressure, CTD temperature, CTD salinity, CTD oxygen, calculated potential temperature, bottle salinity, bottle oxygen, silicate, nitrate, nitrite, phosphate, CFC-11, CFC-12, $\Delta^{14} \mathrm{C}$, calculated ${ }^{14} \mathrm{C}$ error, $\mathrm{TCO}_{2}$, TALK, and data-quality flags. The station inventory file tun1sta.inv (see Part 2) contains the expedition code, section number, station number, cast number, sampling date (i.e., month, day, and year), sampling time, latitude, longitude, and bottom depth for each station.

\subsection{Hydrographic Measurements}

All CTD pressure, temperature, salinity, and oxygen values for the bottle data tabulations were obtained by averaging CTD data for a brief interval at the time the bottle was closed on the rosette. All reported CTD values were calibrated with reference to the International Temperature Scale of 1990 and processed with the methodology described in the documentation accompanying the final CTD data report for the TUNES-1 Expedition. The full cruise report, that includes details about processing the hydrographic data, and the final CTD data are available from the WOCE Hydrographic Programme (WHP) Office (WHPO) or the WHP Special Analysis Center.

Salinity samples were drawn into 200-mL Kimax high-alumina borosilicate glass bottles with custom-made plastic insert thimbles and Nalgene screw caps, which provided low container dissolution and sample evaporation. These bottles were rinsed three times before filling, and measurements were usually made within $8-36 \mathrm{~h}$ after collection. Salinity was determined on the basis of electrical conductivity measured by an SIO Oceanographic Data Facility (ODF)-modified Guildline Autosal Model 8400A salinometer, and the values were obtained according to the equations of the Practical Salinity Scale of 1978 (UNESCO 1981). The salinometer was 
standardized against Wormley P-114 standard seawater, with at least one fresh vial opened per cast. Accuracy estimates of bottle salinities run at sea are usually better then 0.002 relative to the specified batch of standard. Although laboratory precision of the Autosal can be as small as 0.0002 when running replicate samples under ideal conditions, at sea the expected precision was $\sim 0.001$ under normal conditions with a stable laboratory temperature.

Samples were collected for dissolved oxygen analyses soon after the rosette sampler was brought on board and after CFC and helium were drawn. Nominal $100-$ or $125-\mathrm{mL}$ volume iodine flasks were carefully rinsed with minimal agitation, then filled through the use of a drawing tube, and allowed to overflow for at least two flask volumes. Reagents were added to fix the oxygen before stoppering. The flasks were shaken twice - immediately after drawing and then again after $20 \mathrm{~min}$ - to ensure thorough dispersion of the $\mathrm{Mn}(\mathrm{OH})_{2}$ precipitate. The samples were analyzed within 4-36 h.

Dissolved oxygen samples were titrated in the volume-calibrated iodine flasks with a 1-mL microburet, using the whole-bottle Winkler titration following the technique of Carpenter (1965) with modifications by Culberson and Williams (1991). Standardizations were performed with $0.01 \mathrm{~N}$ potassium iodate solutions prepared from preweighed potassium iodate crystals. Standards were run at the beginning of each session of analyses, which typically included from one to three stations. Several standards were prepared. A comparison was then made to ensure that the results were reproducible and to preclude basing the entire cruise on one standard, which would introduce the possibility of a weighing error. A correction was made for the amount of oxygen added with the reagents. Combined reagent/seawater blanks were determined to account for oxidizing or reducing materials in the reagents and for a nominal level of natural iodate or other oxidizers/reducers in the seawater. These latter corrections are contrary to the recommendations of Culberson and Williams (1991), which call for the determination of reagent blanks in distilled water. ODF standard procedures have since been aligned with those recommended by Culberson and Williams (1991).

Oxygen concentrations were converted from milliliters per liter to micromoles per kilogram using the in situ temperature. Ideally, for whole-bottle titrations, the conversion temperature should be the temperature of the water issuing from the Niskin bottle spigot. The temperature of each sample was measured at the time it was drawn from the bottle; however, these values were not used in the conversion from milliliters per liter to micromoles per kilogram because the software was not available. Aberrant temperatures provided an additional flag, indicating that a bottle may not have tripped properly. Measured sample temperatures from middeep water samples were about $4-7^{\circ} \mathrm{C}$ warmer than the in situ temperature. Converted oxygen values, if this conversion with the measured sample temperature were made, would be about $0.08 \%$ higher for a $6^{\circ} \mathrm{C}$ warming (or about $0.2 \mu \mathrm{m} / \mathrm{kg}$ for a $250 \mu \mathrm{m} / \mathrm{kg}$ sample).

Analyses of nutrients (i.e., phosphate, silicate, nitrate, and nitrite), reported in micromoles per kilogram, were performed on a Technicon AutoAnalyzer ${ }^{\circledR}$. The procedures used are described in Atlas et al. (1971). Standardizations were performed with solutions prepared aboard ship from preweighed standards; these solutions were used as working standards before and after each cast (approximately 36 samples) to correct for instrumental drift during analyses. Sets of 4-6 different concentrations of shipboard standards were analyzed periodically to determine the linearity of colorimetric response and the resulting correction factors. Hydrazine reduction of phosphomolybdic acid was used for phosphate analysis, while stannous chloride reduction of silicomolybdic acid was used for silicate analysis. Nitrite was analyzed by using diazotization and coupling to form dye; nitrate was reduced by copperized cadmium and then analyzed as nitrite.

Sampling for nutrients followed that for the tracer gases, CFCs, helium, tritium, $\Delta{ }^{14} \mathrm{C}$, dissolved oxygen, $\mathrm{TCO}_{2}$, and TALK. Samples were drawn into narrow-mouth, screw-capped bottles 
of high-density polyethylene, which were rinsed twice before filling. The samples may have been refrigerated at $2-6^{\circ} \mathrm{C}$ for a maximum of $15 \mathrm{~h}$. Nutrients were converted from micromoles per liter to micromoles per kilogram by dividing by sample density which was calculated at an assumed laboratory temperature of $25^{\circ} \mathrm{C}$.

\subsection{Chlorofluorocarbons Measurements}

The concentrations of dissolved atmospheric chlorofluorocarbons, CFC-11 and CFC-12, were measured by shipboard electron-capture gas chromatography via methods similar to those described by Bullister and Weiss (1988). The measurements were done by the University of Miami group, P.I. Dr. Rana A. Fine, under the analytical direction of Kevin F. Sullivan. A total of 1628 water samples were analyzed from 79 of 124 stations and included eight pairs of duplicate water samples. The mean values of duplicate analyses are reported in the data file and are assigned a quality byte of 6 .

Several times during the cruise, problems with the analytical system required extensive downtime. If samples were drawn but not analyzed, and the downtime exceeded 8 hours, some or all of these samples were discarded and fresh samples were drawn on the current station. This situation occurred after stations 16 and 24. In accordance with WHP protocol, the value for these samples has been reported as -999.900 and they have been assigned a quality byte of 5 .

Occasionally after a routine analysis, the CFC values were clearly inappropriate based on the depth at which the Niskin was tripped. Other measured quantities showed unusual results on some of these occasions. Rather than discard these data, we are reporting their values and have assigned a data quality byte of 4 .

The concentrations of the CFCs in air and water were calculated using external gaseous standards. The gaseous and aqueous analyses were first corrected for any signal due to the analytical system using a weighted average of the four surrounding appropriate blank analyses. The average gaseous blank value was $7.32 \mathrm{e}^{-6}$ picomole (pM) for CFC-12 and $3.16 \mathrm{e}^{-5} \mathrm{pM}$ for CFC-11. The average aqueous blank value was $1.44 \mathrm{e}^{-5} \mathrm{pM}$ for CFC-12 and $9.94 \mathrm{e}^{-5} \mathrm{pM}$ for CFC- 11 .

The temporal variation of the detector was compensated for by calculating a normalization factor for each analysis. Equations that closely resemble straight lines were fit to groupings of normalized standard analyses to yield calibration curves. These calibration curves were applied to the sample analyses to result in the concentrations of the CFCs.

After the water concentrations were calculated, a final correction was applied. This correction was estimated from the samples collected in waters that were very likely free of CFCs and was to compensate for any trace CFCs originating from the sampling bottles and/or handling. The bottle blanks decreased during the cruise; therefore, different bottle blanks for each Niskin were estimated for sequential ranges of stations. For the 36 Niskins during the entire cruise the applied bottle blanks averaged $0.0016 \mathrm{pM} / \mathrm{kg}$ for CFC-12 and $0.0033 \mathrm{pM} / \mathrm{kg}$ for CFC-11. If the bottle blank was greater than the measured concentration, a negative concentration is reported in the data file.

The precision of the water analyses can be estimated from the results of duplicate syringes drawn on the same Niskin. For eight pairs of duplicate syringes the average percent standard deviation for all the pairs was $1.66 \%$ for CFC- 12 and $0.68 \%$ for CFC- 11 . For the samples greater than $0.1 \mathrm{pM} / \mathrm{kg}$, the average percent standard deviation was $1.28 \%$ for CFC-12 $(\mathrm{n}=4)$ and $0.33 \%$ for CFC-11 $(n=5)$. 


\subsection{Radiocarbon Measurements}

During the planning phase of WOCE, the accelerator mass spectrometry (AMS) technique for measuring ${ }^{14} \mathrm{C}$ was still relatively new in the United States. The general procedures had been worked out; however, no laboratory was prepared to handle the large number of samples expected from the WOCE program, nor had it been demonstrated that the AMS technique could deliver the required precision on a routine basis. The National Ocean Sciences AMS Facility (NOSAMS) at WHOI was established in 1989 to serve this purpose. In planning the WOCE Pacific field work, it was recognized that sample collection would begin well before NOSAMS could deliver the high precision offered by conventional beta counting techniques. Therefore, both techniques were utilized.

On those WOCE legs that included both large-volume (LV) and small-volume (SV) sampling, the LV stations were spaced at an average interval of once every five degrees ( $~ 300$ nautical miles). LV stations normally included two casts of nine Gerard barrels each, covering the water column from $\sim 1000 \mathrm{~m}$ to the bottom. The upper kilometer of a LV station was covered by $16 \mathrm{SV}$ samples taken from the CTD/rosette cast. One to three SV stations were placed between each LV station. At SV stations, only the upper thermocline region was sampled. Sixteen SV samples were taken at these stations.

Radiocarbon was extracted from the LV samples at sea as ${ }^{14} \mathrm{CO}_{2}$, absorbed on excess $\mathrm{NaOH}$ and returned to shore in well-sealed glass bottles using a modification of the technique described by Fonselius and Östlund (1959). Once ashore the samples were sent to researches at one of two laboratories for analysis: G. Östlund, Tritium Laboratory, University of Miami, Miami; or M. Stuiver, Quaternary Isotope Laboratory, University of Washington, Seattle. A short description of the measurement procedure and a cross-check between these two laboratories are available in Stuiver et al. (1974). Stuiver reports an error estimate for each analysis that ranges from 2.5 to 4.0 per mille (\%o), while Östlund reports a uniform sample error of 4\%o. In both cases the reported uncertainty is primarily counting error and does not include any error due to sample collection.

All SV ${ }^{14} \mathrm{C}$ samples were collected from standard CTD/rosette casts into 500 -mL glass bottles fitted with high-quality ground-glass stoppers. The samples were poisoned with $\mathrm{HgCl}_{2}$ immediately after collection and then returned to the United States for extraction and analysis at NOSAMS. Details of the extraction, counting, etc., are available from Key (1991), McNichol and Jones (1991), Gagnon and Jones (1993), and Cohen et al. (1994). The standard used for the ${ }^{14} \mathrm{C}$ measurements is the National Bureau of Standards oxalic acid standard for radiocarbon dating. All results are reported as $\Delta^{14} \mathrm{C}$, which is the deviation (in \%o) from unity of the activity ratio of sample to standard, isotope corrected to a sample $\delta^{13} \mathrm{C}$ value of $-25 \%$, where $\delta{ }^{13} \mathrm{C}$ was calculated from

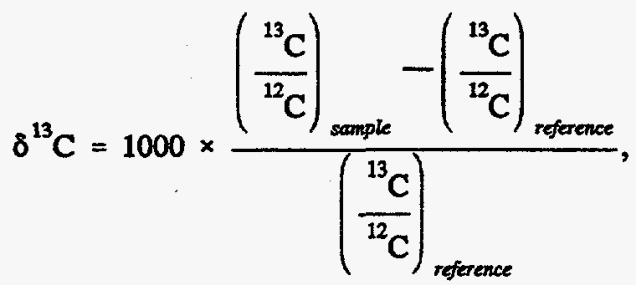

to correct for fractionation and dilution by anthropogenic $\mathrm{CO}_{2}$. For more information on standards and calculation methods, refer to the papers by Broecker and Olson (1961), Stuiver and Robinson (1974), and Stuiver (1980). As measurements were completed, the results were communicated from the analytical laboratory to the principal investigator responsible for the cruise via periodic data reports. $\mathrm{R}$. Key gathered the $\Delta{ }^{14} \mathrm{C}$ data; merged it with hydrographic data supplied by either the chief scientist or WHPO; added WOCE quality-control flags; and finally submitted the data to 
WHPO along with a final report for the WOCE Section P17C, Cruise TUNES, Leg 1 (Key, 1996a, b). All of the LV samples collected in the Pacific Ocean will be processed by 1997, and the Pacific SV samples will be completed by 1998.

During the GEOSECS Program, the precision of the LV technique was established as $2-4 \%$. This precision is primarily a function of sample counting time and has remained constant throughout the succeeding large-scale ocean-survey programs. At the beginning of WOCE, the ultimate precision of the AMS technique and the degree of compatibility of the AMS and LV data (i.e., the absence of systematic errors in either data set) were unknown. NOSAMS is currently processing water samples with a mean "external" precision of 3.6\%o. This degree of precision is indicative of the AMS target preparation and counting and does not include any uncertainty resulting from sample collection, storage, or stripping. A better estimate of the sample precision can be obtained by comparing the results from duplicate samples. A summary of all the true WOCE duplicates (i.e., two different sample bottles rather than two analyses from the same bottle) analyzed at NOSAMS through mid-1996 shows that the average standard deviation for the pairs was $4.6 \%$. The reason for the difference between this number and the external precision estimate $(3.6 \%)$ is currently unknown; however, it is attributed to either sample collection or sample processing prior to counting. Sample storage experiments at NOSAMS and other facilities have so far indicated that this is not a source of error. A reproducibility of 3\%o is needed for the AMS technique to be equivalent to the average uncertainty for the LV technique.

\subsection{Total $\mathrm{CO}_{2}$ Measurements}

During the TUNES-1 Expedition, 1022 seawater samples were analyzed for $\mathrm{TCO}_{2}$ concentrations in seawater. The sampling frequency for measurements of the carbonate parameters was reduced to a complete depth profile (36 samples) at approximately every third hydrographic station (Fig. 2). This reduction in sampling was implemented not on the basis of any prearranged geophysical criterion but to accommodate the time constraints of the two analysts on board who performed $\mathrm{CO}_{2}$ sampling and measurements. In other words, the $\mathrm{CO}_{2}$ sampling strategy adopted was to measure as many samples as was technically and humanly possible.

For $\mathrm{TCO}_{2}$ measurements, the seawater samples were drawn into $250-\mathrm{mL}$ standard borosilicate glass, screw-cap bottles, poisoned with $50 \mu \mathrm{L}$ of a saturated solution of mercuric chloride $\left(\mathrm{HgCl}_{2}\right)$, stored at room temperature, and analyzed on board (generally within $18 \mathrm{~h}$ ). $\mathrm{TCO}_{2}$ concentration was measured by semiautomated coulometry, using an improved version of the instrument earlier described by Johnson et al. $(1985,1987)$. This early "SOMMA-type" system did not have gas loops for calibration. Consequently, plans were to calibrate the system with standard solutions prepared as described in Goyet and Hacker (1992); however, these standard solutions could not be prepared on board during the cruise. The certified reference materials were used as standards to calibrate the $\mathrm{TCO}_{2}$ extraction/coulometer system. The latter worked consistently well throughout the cruise. Precision of the measurements was estimated to be better than $\pm 3 \mu \mathrm{mol} / \mathrm{kg}$; the desired accuracy was better than $\pm 4 \mu \mathrm{mol} / \mathrm{kg}$.

The automated coulometric system forced the sample into the pipette using a pressurized headspace gas. Pure nitrogen $\left(\mathrm{N}_{2}\right)$ headspace gas was used for measurements of standards, and $\mathrm{CO}_{2}$ headspace gas ( $290 \mathrm{ppm}$ in air) was used for measurements of seawater samples. The volume of the pipette was calibrated with distilled water and seawater (volume was $\sim 30 \mathrm{~mL}$, depending on the individual pipette used), and there was no significant difference in the delivery volume as a result of possible differences in surface tension at different salinities. The sample was drained from the pipette into a stripper containing $1.5 \mathrm{~mL}$ of $8.5 \%$ phosphoric acid. 
This chamber and the added acid were purged of any $\mathrm{CO}_{2}$ with pure $\mathrm{N}_{2}$ carrier gas before the sample was added. In the stripper, the $\mathrm{CO}_{2}$ gas was extracted from the acidified sample by a continuous flow of pure $\mathrm{N}_{2}$ gas through a frit at the bottom of the stripper. The gas (mainly $\mathrm{CO}_{2}$, $\mathrm{N}_{2}$, and water vapor) was passed through a condenser thermostated with $4^{\circ} \mathrm{C}$ water and magnesium perchlorate $\left[\mathrm{Mg}\left(\mathrm{ClO}_{4}\right)_{2}\right]$ to remove water vapor. It was then passed through silica gel to remove residual aerosols and traces of hydrogen sulfide $\left(\mathrm{H}_{2} \mathrm{~S}\right)$ and phosphoric acid $\left(\mathrm{H}_{3} \mathrm{PO}_{4}\right)$ before being bubbled into a commercially available coulometric solution containing ethanolamine $\left[\mathrm{NH}_{2}\left(\mathrm{CH}_{2}\right)_{2} \mathrm{OH}\right]$, dimethyl sulfoxide $\left[\left(\mathrm{CH}_{3}\right)_{2} \mathrm{SO}\right]$, and thymolphthalein dye (made by UIC, Inc., Joliet, Illinois). A coil made from glass tubing with thermostated water flowing through it was placed in the cell to maintain the solution at $24^{\circ} \mathrm{C}$. The $\mathrm{pH}$ of the solution was monitored on total $\mathrm{CO}_{2}$ coulometer (UIC, Inc.) by monitoring the thymolphthalein-absorbance indicator at $\sim 610 \mathrm{~nm}$. Hydroxide $\left(\mathrm{OH}^{-}\right)$ions were generated by the coulometer circuitry to maintain absorbance of the solution at a constant value. The analytical procedure was controlled by a microcomputer that also recorded the coulometric titration and computed the total $\mathrm{CO}_{2}$ extracted from the sample based on the amount of $\mathrm{OH}^{-}$generated to reach the endpoint.

\subsection{Total Alkalinity Measurements}

TALK samples were collected in 250-mL standard borosilicate glass, screw-cap bottles and poisoned with $50 \mu \mathrm{L}$ of saturated $\mathrm{HgCl}_{2}$ solution. The samples were stored at room temperature and measured on board, generally within $18 \mathrm{~h}$. TALK was determined by potentiometric titration; the method used was derived from one first described by Dyrssen (1965) and later modified by Bradshaw et al. (1981). The automated titration was performed in a closed cell maintained at constant temperature $\left(25 \pm 0.1^{\circ} \mathrm{C}\right)$; the ionic strength of the hydrochloric acid solution $(0.1 \mathrm{~N})$ was adjusted with $\mathrm{NaCl}$ to increase its similarity to seawater. The ratio of the acid normality to the cell volume was calibrated before and after the sample analysis. Calibration consisted of preparing solutions of known TALK concentration and measuring them as described by Brewer et al. (1986). The precision of the measurements was estimated to be better than $0.1 \%$.

\subsection{Shore-Based Replicate Measurements}

The replicate samples from 56 Niskin bottles at 18 stations were collected for shore-based reference analyses at the laboratory of $\mathrm{C}$. D. Keeling of SIO. The $\mathrm{TCO}_{2}$ measurements were produced by vacuum-extraction/manometric analysis, and the TALK values, by potentiometric titration. Both measurements were performed under controlled laboratory conditions using standards. The replicate sample standard deviation $(s)$ for this large data set of 50 unflagged pairs is $1.9 \mu \mathrm{mol} / \mathrm{kg}$ after the three replicate pairs with deltas greater then $3 s$ (a replicate sample standard deviation calculated from the set of analyses on duplicate samples) were omitted (Guenther et al. 1994). Figure 3 displays the performance of the replicate sampling program during TUNES Leg 1 for a subset of all data including only near surface $(0-10 \mathrm{~m})$ and deep $(-3000 \mathrm{~m})$ data. Two data points with replicate sample singlets are omitted, as well as one with a ship-minus-shore difference of $-30.6 \mu \mathrm{mol} / \mathrm{kg}$ and one with a replicate delta greater then $4.0 \mu \mathrm{mol} / \mathrm{kg}$ (Guenther et al. 1994).

For the 17 comparisons, the replicate $s$ is $0.9 \mu \mathrm{mol} / \mathrm{kg}$, similar to the $s$ calculated for the entire data set. Figure 3 illustrates that the near-surface data are in better agreement than the deep data. Because 12 of the 17 comparisons are between values for surface data, their better agreement weighs the subset and produces lack of agreement with the entire data set. Figure 3 illustrates better 
performance of the replicate sampling program at the onset of TUNES-1, with more scatter of the data evident towards the end of the leg (Guenther et al. 1994).

Tables 1 and 2, reprinted from Guenther et al. 1994, summarize the replicate shore-based measurements of $\mathrm{TCO}_{2}$ and TALK and their comparisons with shipboard measurements. 


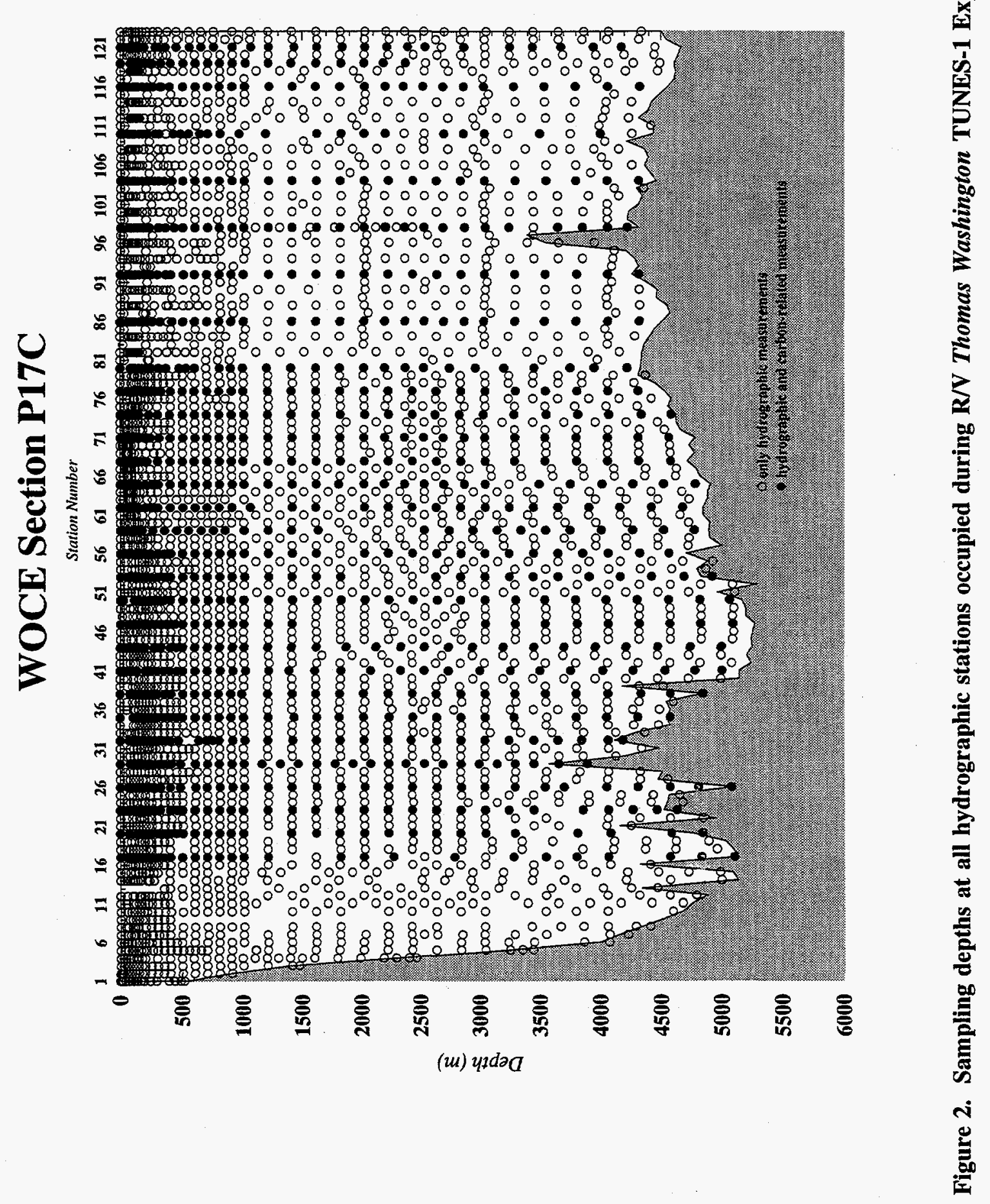




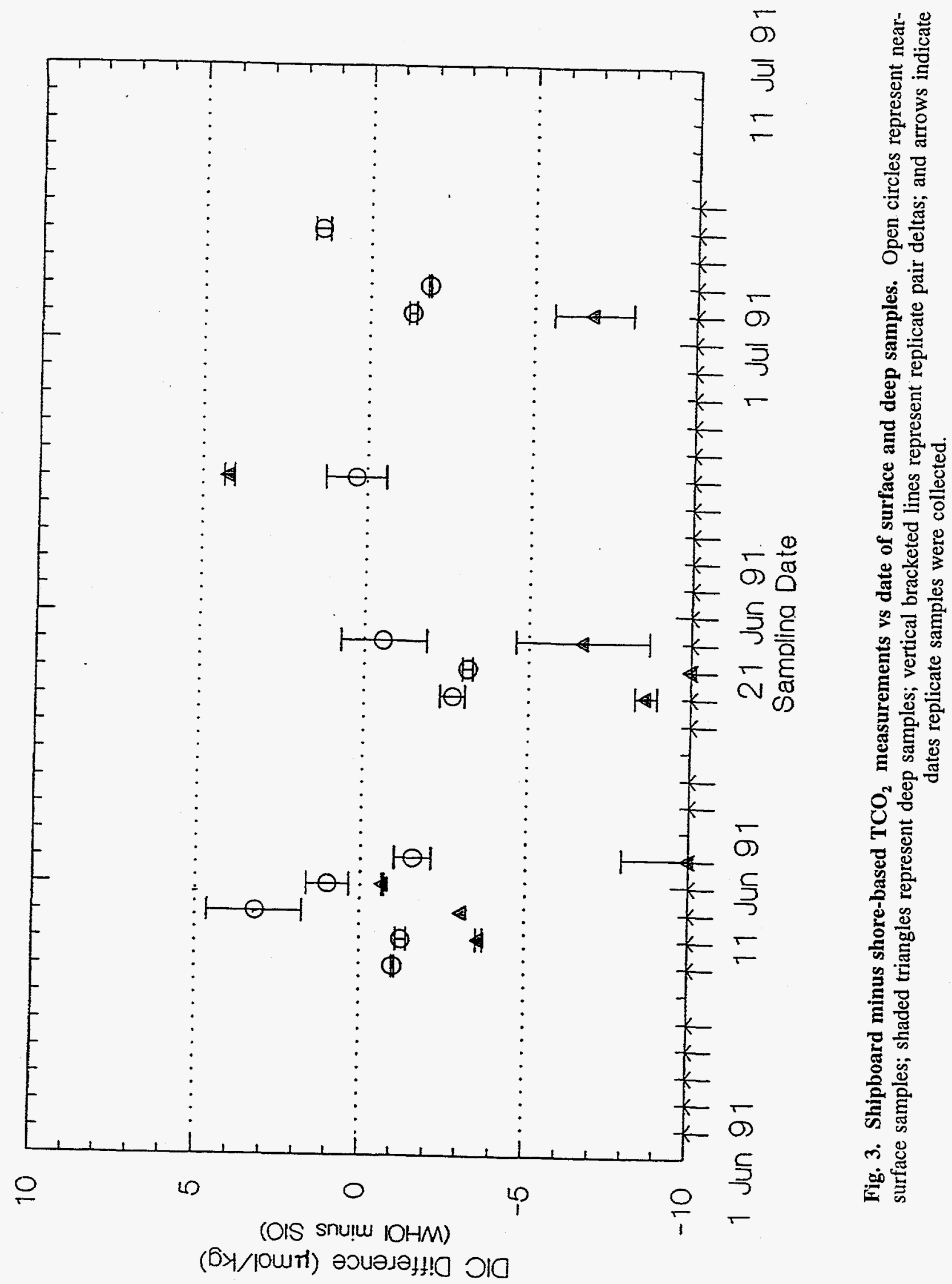


Table 1. Summary of $\mathrm{TCO}_{2}$ replicate data collected during R/V Thomas Washington TUNES-1 Expedition THE CARBON DIOXIDE PROJECT OF THE SCRIPPS INSTITUTION OF OCEANOGRAPHY
TUNES Leg 1 1991 PaCific WOCE Line P17C

SUMMARY OF DISSOLVED INORGANTC CARBON DATA

\begin{tabular}{|c|c|c|c|c|c|c|c|c|c|c|c|c|c|c|c|c|c|c|}
\hline LEG & LAT. & CAS & & DEPTH & SAMPLE & EXTRAC & ANALYSIS & MANO & SAMPLE & RIN & FTAG & S.I.O. & $\begin{array}{c}\text { RUN } \\
\text { DELTA }\end{array}$ & $\begin{array}{l}\text { BOTTLE } \\
\text { DIC }\end{array}$ & $\begin{array}{l}\text { BOTTLE " } \\
\text { DELTA }\end{array}$ & $\begin{array}{l}\text { "NISKIN" } \\
\text { AVG }\end{array}$ & $\begin{array}{l}\text { WHOI } \\
\text { DIC }\end{array}$ & $\begin{array}{r}\text { WHOI } \\
\text {-S.I.O. }\end{array}$ \\
\hline $1_{5}$ & $\begin{array}{r}35-33 N \\
122-52 W\end{array}$ & 1 & 1 & 1 & 03JUN91. & $\begin{array}{l}\text { 20AUG91 } \\
\text { 21AUG91 }\end{array}$ & $\begin{array}{l}\text { 22AUG91 } \\
\text { 22AUG91 }\end{array}$ & $\begin{array}{l}s \\
s\end{array}$ & $\begin{array}{l}\mathbf{S} 3750 \\
\$ 3751\end{array}$ & $\begin{array}{l}001 \\
001\end{array}$ & & $\begin{array}{l}1982.51 \\
1983.22\end{array}$ & & $\begin{array}{l}1982.51 \\
1983.22\end{array}$ & +0.71 & 1982.86 & & \\
\hline \multirow[t]{2}{*}{$1_{8}$} & $\begin{array}{r}34-49 N \\
124-35 W\end{array}$ & 1 & 1 & 1 & 04JUNN91 & $\begin{array}{l}\text { 21AUG91 } \\
\text { 22AUG91 }\end{array}$ & $\begin{array}{l}\text { 22AUG91 } \\
\text { 22AUG91 }\end{array}$ & $\begin{array}{l}s \\
s\end{array}$ & $\begin{array}{l}\$ 3772 \\
\mathbf{S} 3773\end{array}$ & $\begin{array}{l}001 \\
001\end{array}$ & & $\begin{array}{l}1984.63 \\
1982.71\end{array}$ & & $\begin{array}{l}1984.63 \\
1982.71\end{array}$ & -1.92 & 1983.67 & & \\
\hline & & 1 & 3 & 66 & & $\begin{array}{l}\text { 21AUG91 } \\
\text { 21AUG91 }\end{array}$ & $\begin{array}{l}\text { 22AUG91 } \\
\text { 22AUG91 }\end{array}$ & $\begin{array}{l}\mathbf{S} \\
\mathbf{S}\end{array}$ & $\begin{array}{l}\$ 3770 \\
\$ 3771\end{array}$ & $\begin{array}{l}001 \\
001\end{array}$ & & $\begin{array}{l}2027.65 \\
2028.92\end{array}$ & & $\begin{array}{l}2027.65 \\
2028.92\end{array}$ & +1.27 & 2028.29 & & \\
\hline $\begin{array}{l}1 \\
11\end{array}$ & $\begin{array}{r}34-35 \mathrm{~N} \\
127-38 \mathrm{~W}\end{array}$ & 1 & 29 & 2896 & 05JUN9 1 & 22AUG91 & 28AUG91 & $s$ & S3774 & 001 & & 2377.63 & & 2377.63 & & 2377.63 & & \\
\hline $\begin{array}{l}1 \\
14\end{array}$ & $\begin{array}{r}34-35 \mathrm{~N} \\
131-19 \mathrm{~W}\end{array}$ & 1 & 1 & 2 & 07JUN91 & $\begin{array}{l}\text { 22AUG91 } \\
\text { 23AUG91 }\end{array}$ & $\begin{array}{l}\text { 28AUG91 } \\
\text { 28AUG91 }\end{array}$ & $\stackrel{s}{S}$ & $\begin{array}{l}\$ 3781 \\
\$ 3782\end{array}$ & $\begin{array}{l}001 \\
001\end{array}$ & & $\begin{array}{l}1993.44 \\
1986.40\end{array}$ & & $\begin{array}{l}1993.44 \\
1986.40\end{array}$ & -7.04 & 1989.92 & & \\
\hline \multirow[t]{10}{*}{$\begin{array}{l}1 \\
17\end{array}$} & $\begin{array}{r}34-36 \mathrm{~N} \\
134-58 \mathrm{~W}\end{array}$ & 2 & 1 & 1 & 08JUN9 1 & $\begin{array}{l}\text { 09SEP91 } \\
\text { 10SEP91 }\end{array}$ & $\begin{array}{l}\text { 12SEP91 } \\
\text { 12SEP91 }\end{array}$ & $\begin{array}{l}\mathrm{s} \\
\mathrm{s}\end{array}$ & $\begin{array}{l}\mathbf{S} 3806 \\
\mathbf{S 3 8 0 7}\end{array}$ & $\begin{array}{l}001 \\
001\end{array}$ & & $\begin{array}{l}1988.39 \\
1988.47\end{array}$ & & $\begin{array}{l}1988.39 \\
1988.47\end{array}$ & +0.08 & 1988.43 & 1987.4 & -1.03 \\
\hline & & 2 & 2 & 52 & & $\begin{array}{l}\text { 10SEP91 } \\
\text { 09SEP91 }\end{array}$ & $\begin{array}{l}\text { 12SEP91 } \\
\text { 12SEP91 }\end{array}$ & $\begin{array}{l}s \\
s\end{array}$ & $\begin{array}{l}\$ 3804 \\
\$ 3805\end{array}$ & $\begin{array}{l}001 \\
001\end{array}$ & & $\begin{array}{l}1982.28 \\
1984.65\end{array}$ & & $\begin{array}{l}1982.28 \\
1984.65\end{array}$ & +2.37 & 1983.47 & 1982.5 & -0.97 \\
\hline & & 2 & 4 & 98 & & 09SEP91 & 12SEP 91 & $\mathbf{s}$ & $\$ 3802$ & 001 & & 1993.50 & & 1993.50 & & 1993.50 & 1975.9 & -17.60 \\
\hline & & 2 & 8 & 201 & & $\begin{array}{l}\text { 29AUG91 } \\
\text { 29AUG91 }\end{array}$ & $\begin{array}{l}\text { 29AUG91 } \\
\text { 29AUG91 }\end{array}$ & $\begin{array}{l}S \\
S\end{array}$ & $\begin{array}{l}\$ 3800 \\
\$ 3801\end{array}$ & $\begin{array}{l}001 \\
001\end{array}$ & & $\begin{array}{l}2098.60 \\
2107.24\end{array}$ & & $\begin{array}{l}2098.60 \\
2107.24\end{array}$ & +8.64 & 2102.92 & 2096.8 & -6.12 \\
\hline & & 2 & 10 & 300 & & $\begin{array}{l}\text { 28AUG91 } \\
\text { 28AUG91 }\end{array}$ & $\begin{array}{l}\text { 29AUG91 } \\
\text { 29AUG91 }\end{array}$ & $\begin{array}{l}S \\
S\end{array}$ & $\begin{array}{l}\$ 3798 \\
\$ 3799\end{array}$ & $\begin{array}{l}001 \\
001\end{array}$ & & $\begin{array}{l}2179.95 \\
2180.55\end{array}$ & & $\begin{array}{l}2179.95 \\
2180.55\end{array}$ & +0.60 & 2180.25 & 2177.6 & -2.65 \\
\hline & & 2 & 12 & 401 & & $\begin{array}{l}\text { 26AUG91 } \\
\text { 26AUG91 }\end{array}$ & $\begin{array}{l}\text { 29AUG91 } \\
\text { 29AUG91 }\end{array}$ & $\begin{array}{l}S \\
S\end{array}$ & $\begin{array}{l}\$ 3796 \\
\text { S3797 }\end{array}$ & $\begin{array}{l}001 \\
001\end{array}$ & & $\begin{array}{l}2235.29 \\
2234.32\end{array}$ & & $\begin{array}{l}2235.29 \\
2234.32\end{array}$ & -0.97 & 2234.81 & 2225.6 & -9.21 \\
\hline & & 2 & 14 & 601 & & $\begin{array}{l}\text { 26AUG91 } \\
\text { 26AUG91 }\end{array}$ & $\begin{array}{l}\text { 28AUG91 } \\
\text { 29AUG91 }\end{array}$ & $\begin{array}{l}S \\
S\end{array}$ & $\begin{array}{l}\$ 3794 \\
\text { S3795 }\end{array}$ & $\begin{array}{l}001 \\
001\end{array}$ & & $\begin{array}{l}2309.78 \\
2311.76\end{array}$ & & $\begin{array}{l}2309.78 \\
2311.76\end{array}$ & +1.98 & 2310.77 & 2302.8 & -7.97 \\
\hline & & 2 & 17 & 899 & & $\begin{array}{l}\text { 26AUG91 } \\
\text { 26AUG91 }\end{array}$ & $\begin{array}{l}\text { 28AUG91 } \\
\text { 28AUG91 }\end{array}$ & $\begin{array}{l}S \\
S\end{array}$ & $\begin{array}{l}\$ 3792 \\
\$ 3793\end{array}$ & $\begin{array}{l}001 \\
001\end{array}$ & & $\begin{array}{r}2365.29 \\
2367.90\end{array}$ & & $\begin{array}{l}2365.29 \\
2367.90\end{array}$ & +2.61 & 2366.59 & 2351.1 & -15.49 \\
\hline & & 2 & 19 & 1200 & & $\begin{array}{l}\text { 23AUGG91 } \\
\text { 23AUG91 }\end{array}$ & $\begin{array}{l}\text { 28AUG91 } \\
\text { 28AUG91 }\end{array}$ & $\begin{array}{l}\mathrm{s} \\
\mathrm{s}\end{array}$ & $\begin{array}{l}\mathbf{S} 3790 \\
\mathbf{S 3 7 9 1}\end{array}$ & $\begin{array}{l}001 \\
001\end{array}$ & & $\begin{array}{l}2373.67 \\
2373.97\end{array}$ & & $\begin{array}{l}2373.67 \\
2373.97\end{array}$ & +0.30 & 2373.82 & & \\
\hline & & 2 & 21 & 1600 & & $\begin{array}{l}\text { 23AUG9 } 1 \\
\text { 23AUG91 }\end{array}$ & $\begin{array}{l}\text { 28AUG91 } \\
28 \text { AUG91 }\end{array}$ & $\begin{array}{l}S \\
S\end{array}$ & $\begin{array}{l}\$ 3788 \\
\$ 3789\end{array}$ & $\begin{array}{l}001 \\
001\end{array}$ & & $\begin{array}{l}2377.93 \\
2386.04\end{array}$ & & $\begin{array}{l}2377.93 \\
2386.04\end{array}$ & +8.11 & 2381.99 & & \\
\hline
\end{tabular}

MANOMETER TYPE: 28AUG91

FLAGS

$\mathrm{F}:$ No $\mathrm{Hg}$ found in bottle

I = CONSTA SPIRAL MOLUME MERCTRY DATUM

BOTTLE TYPE:

$=$ RODAVISS $S=S$ TYPE

Data excluded from analysis 
Table 1 (continued)

THE CARBON DIOXIDE PROJECT OF THE SCRIPPS INSTITUTION OF OCEANOGRAPHY TUNES Leg 11991 Pacific WOCE Line P17C

SUMMARY OF DISSOLVED INORGANIC CARBON DATA (cont)

\begin{tabular}{|c|c|c|c|c|c|c|c|c|c|c|c|c|c|c|c|c|c|c|}
\hline $\begin{array}{l}\text { LEG } \\
\text { STN }\end{array}$ & $\begin{array}{l}\text { LAT. } \\
\text { LONG. }\end{array}$ & $\begin{array}{l}\text { CAS } \\
\text { NIS }\end{array}$ & & $\begin{array}{l}\text { DEPTH } \\
\text { (M) }\end{array}$ & $\begin{array}{l}\text { SAMPLE } \\
\text { DATE }\end{array}$ & $\begin{array}{c}\text { EXTRAC } \\
\text { DATE }\end{array}$ & $\begin{array}{l}\text { ANALYSIS } \\
\text { DATE }\end{array}$ & $\begin{array}{l}\text { MANO } \\
\text { TYPE }\end{array}$ & $\begin{array}{l}\text { SAMPLE } \\
\text { BO'TTLEE }\end{array}$ & RUN & FLAG & $\begin{array}{l}\text { S.I.O. } \\
\text { RUN }\end{array}$ & $\begin{array}{c}\text { RUN } \\
\text { DELTA }\end{array}$ & $\begin{array}{l}\text { BOTTLE } \\
\text { DIC } \\
--\quad(\mu \text { MOLE }\end{array}$ & $\begin{array}{l}\text { BOTTLE } \\
\text { DELTA } \\
\text { S/KG SW }\end{array}$ & $\begin{array}{c}\text { "NISKIN" } \\
\text { AVG }\end{array}$ & $\begin{array}{l}\text { WHOI } \\
\text { DIC }\end{array}$ & $\begin{array}{r}\text { WHOI } \\
\text {-S. I. }\end{array}$ \\
\hline \multirow[t]{2}{*}{$\begin{array}{l}1 \\
20\end{array}$} & $\begin{array}{r}33-4 \mathrm{~N} \\
135-00 \mathrm{~W}\end{array}$ & 1 & 1 & 1 & 09.JUN91 & $\begin{array}{l}\text { 20SEP91 } \\
\text { 20SEP91 }\end{array}$ & $\begin{array}{l}\text { 26SEP91 } \\
\text { 26SEP91 }\end{array}$ & $\begin{array}{l}\mathrm{s} \\
\mathrm{s}\end{array}$ & $\begin{array}{l}53810 \\
\text { S3811 }\end{array}$ & $\begin{array}{l}001 \\
001\end{array}$ & & $\begin{array}{l}2002.42 \\
2002.10\end{array}$ & & $\begin{array}{l}2002.42 \\
2002.10\end{array}$ & -0.32 & 2002.26 & 2001.0 & -1.26 \\
\hline & & 1 & 28 & 2798 & & $\begin{array}{l}\text { 17SEP91 } \\
19 \text { SEP91 }\end{array}$ & $\begin{array}{l}\text { 20SEP91 } \\
\text { 20SEP91. }\end{array}$ & $\begin{array}{l}\mathbf{S} \\
\mathbf{S}\end{array}$ & $\begin{array}{l}53808 \\
\text { S3809 }\end{array}$ & $\begin{array}{l}001 \\
001\end{array}$ & & $\begin{array}{l}2362.65 \\
2362.85\end{array}$ & & $\begin{array}{l}2362.65 \\
2362.85\end{array}$ & +0.20 & 2362.75 & 2359.1 & -3.65 \\
\hline \multirow[t]{2}{*}{$\begin{array}{l}1 \\
23\end{array}$} & $\begin{array}{r}31-32 N \\
135-O W\end{array}$ & 1 & 1 & 0 & 10JUN91 & $\begin{array}{l}\text { 24SEP91 } \\
24 \text { SEP91 }\end{array}$ & $\begin{array}{l}\text { 26SEP91 } \\
26 \text { SEP91 }\end{array}$ & $\begin{array}{l}S \\
S\end{array}$ & $\begin{array}{l}\text { S3814 } \\
\text { S3815 }\end{array}$ & $\begin{array}{l}001 \\
001\end{array}$ & & $\begin{array}{l}2007.87 \\
2010.70\end{array}$ & & $\begin{array}{l}2007.87 \\
2010.70\end{array}$ & +2.83 & 2009.29 & 2012.5 & 3.21 \\
\hline & & 1 & 28 & 3003 & & 24SEP91 & $26 \mathrm{SEP} 91$ & $s$ & 53813 & 001 & & 2356.61 & & 2356.61 & & 2356.61 & 2353.5 & -3.11 \\
\hline \multirow[t]{10}{*}{$\begin{array}{l}1 \\
26\end{array}$} & $\begin{array}{r}30-2 \mathrm{~N} \\
134-57 W\end{array}$ & 2 & 1 & 1 & 11JUN91 & $\begin{array}{l}\text { 19AUG91 } \\
\text { 19AUG91 }\end{array}$ & $\begin{array}{l}\text { 22AUG91 } \\
\text { 22AUG91 }\end{array}$ & $\begin{array}{l}\mathbf{S} \\
\mathbf{S}\end{array}$ & $\begin{array}{l}\text { R4478 } \\
\text { R4479 }\end{array}$ & $\begin{array}{l}001 \\
001\end{array}$ & & $\begin{array}{l}2021.92 \\
2020.63\end{array}$ & & $\begin{array}{l}2021.92 \\
2020.63\end{array}$ & -1.29 & 2021.28 & 2022.3 & 1.02 \\
\hline & & 2 & 2 & 64 & & $\begin{array}{l}\text { 09AUG91 } \\
\text { 09AUG91 }\end{array}$ & $\begin{array}{l}\text { 12AUG91 } \\
\text { 12AUG91 }\end{array}$ & $\begin{array}{l}\mathbf{S} \\
\mathbf{S}\end{array}$ & $\begin{array}{l}\text { R4476 } \\
\text { R4477 }\end{array}$ & $\begin{array}{l}001 \\
001\end{array}$ & & $\begin{array}{l}2031.34 \\
2027.18\end{array}$ & & $\begin{array}{l}2031.34 \\
2027.18\end{array}$ & $-4,16$ & 2029.26 & 2020.8 & -8.46 \\
\hline & & 2 & 4 & 109 & & $\begin{array}{l}\text { OBAUG91 } \\
\text { OBAUG91 } 1\end{array}$ & $\begin{array}{l}\text { 12AUG91 } \\
12 \text { AUG91 }\end{array}$ & $\begin{array}{l}\mathbf{S} \\
\mathbf{S}\end{array}$ & $\begin{array}{l}\text { R4474 } \\
\text { R4475 }\end{array}$ & $\begin{array}{l}001 \\
001\end{array}$ & & $\begin{array}{l}2032.43 \\
2030.79\end{array}$ & & $\begin{array}{l}2032.43 \\
2030.79\end{array}$ & -1.64 & 2031.61 & 2021.7 & -9.91 \\
\hline & & 2 & 7 & 206 & & $\begin{array}{l}\text { 06AUG91 } \\
\text { 08AUG91 }\end{array}$ & $\begin{array}{l}\text { 07AUG91 } \\
\text { 12AUG91 }\end{array}$ & $\stackrel{s}{S}$ & $\begin{array}{l}\text { R4472 } \\
\text { R4473 }\end{array}$ & $\begin{array}{l}001 \\
001\end{array}$ & & $\begin{array}{l}2044.07 \\
2043.64\end{array}$ & & $\begin{array}{l}2044.07 \\
2043.64\end{array}$ & -0.43 & 2043.85 & 2041.7 & -2.15 \\
\hline & & 2 & 10 & 324 & & $\begin{array}{l}\text { O6AUG91 } \\
\text { 06AUG91 } 1\end{array}$ & $\begin{array}{l}\text { 07AUG91 } \\
\text { 07AUG91 }\end{array}$ & $\begin{array}{l}S \\
S\end{array}$ & $\begin{array}{l}\mathrm{R} 4470 \\
\mathrm{R} 4471\end{array}$ & $\begin{array}{l}001 \\
001\end{array}$ & & $\begin{array}{l}2099.91 \\
2099.87\end{array}$ & & $\begin{array}{l}2099.91 \\
2099.87\end{array}$ & -0.04 & 2099.89 & 2099.3 & -0.59 \\
\hline & & 2 & 11 & 400 & & $\begin{array}{l}\text { 05AUG91 } \\
\text { 05AUG91 }\end{array}$ & $\begin{array}{l}\text { 07AUG91 } \\
\text { 07AUG91 }\end{array}$ & $\mathbf{S}$ & $\begin{array}{l}\text { R4468 } \\
\text { R4469 }\end{array}$ & $\begin{array}{l}001 \\
001\end{array}$ & EX & $\begin{array}{l}2166.40 \\
2149.91\end{array}$ & & 2149.91 & & 2149.91 & 2146.1 & -3.81 \\
\hline & & 2 & 13 & 606 & & $\begin{array}{l}\text { 05AUG91 } \\
\text { 05AUG91 }\end{array}$ & $\begin{array}{l}\text { 07AUG91 } \\
\text { 07AUG91 }\end{array}$ & $\begin{array}{l}\mathbf{S} \\
\mathbf{S}\end{array}$ & $\begin{array}{l}\text { R4466 } \\
\text { R4467 }\end{array}$ & $\begin{array}{l}001 \\
001\end{array}$ & & $\begin{array}{l}2283.85 \\
2284.53\end{array}$ & & $\begin{array}{l}2283.85 \\
2284.53\end{array}$ & +0.68 & 2284.19 & 2282.1 & -2.09 \\
\hline & & 2 & 16 & 909 & & $\begin{array}{l}\text { 26SEP91 } \\
26 \text { SEP91 }\end{array}$ & $\begin{array}{l}\text { 26SEP91 } \\
26 \text { SEP91 }\end{array}$ & $\begin{array}{l}S \\
S\end{array}$ & $\begin{array}{l}\text { s3824 } \\
\text { s3825 }\end{array}$ & $\begin{array}{l}001 \\
001\end{array}$ & & $\begin{array}{l}2354.87 \\
2354.57\end{array}$ & & $\begin{array}{l}2354.87 \\
2354.57\end{array}$ & -0.30 & 2354.72 & 2351.5 & -3.22 \\
\hline & & 2 & 18 & 1202 & & $\begin{array}{l}\text { 27SEP91 } \\
\text { 27SEP91 }\end{array}$ & $\begin{array}{l}\text { 020CT91 } \\
\text { 020CT91 }\end{array}$ & $\stackrel{S}{S}$ & $\begin{array}{l}\$ 3822 \\
\$ 3823\end{array}$ & $\begin{array}{l}001 \\
001\end{array}$ & & $\begin{array}{l}2374.15 \\
2370.18\end{array}$ & & $\begin{array}{l}2374.15 \\
2370.18\end{array}$ & -3.97 & 2372.17 & 2365.6 & -6.57 \\
\hline & & 2 & 20 & 1605 & & $\begin{array}{l}\text { 25SEP91 } \\
27 \text { SEP91 }\end{array}$ & $\begin{array}{l}\text { 26SEP91 } \\
\text { 020CT91 }\end{array}$ & $\begin{array}{l}\mathbf{s} \\
\mathbf{s}\end{array}$ & $\begin{array}{l}53820 \\
S 3821\end{array}$ & $\begin{array}{l}001 \\
001\end{array}$ & & $\begin{array}{l}2372.06 \\
2371.81\end{array}$ & & $\begin{array}{l}2372.06 \\
2371.81\end{array}$ & -0.25 & 2371.94 & 2368.7 & -3.24 \\
\hline
\end{tabular}

MANOMETER TYPE

FLAGS:

$S=$ QUARTZ SPIRAL MANOMETER DATUM

$\mathrm{F}$ : No $\mathrm{Hg}$ found in bottle

$\stackrel{M}{M}=$ CONSTANT VOLUME MERCURY MANOMETER DATUM

G: Severe bottle leak

$\begin{aligned} \text { BOTTLE TYPE: } & \\ \mathrm{R} & =\text { RODAVIS }\end{aligned}$

$S=S$ TYPE

EX: Data excluded from analysis 
Table 1 (continued)

THE CARBON DIOXIDE PROJECT OF THE SCRIPPS INSTITUTION OF OCEANOGRAPHY TUNES Leg 1991 Pacific WOCE Line P17C

SUMMARY OF DISSOLVED INORGANIC CARBON DATA (cont)

\begin{tabular}{|c|c|c|c|c|c|c|c|c|c|c|c|c|c|c|c|c|c|c|}
\hline LEG & LAT. & CAST & & DEPTH & SAMPLE & EXTRAC & ANALYSIS & MANO & SAMPLE & BIIN & FLAG & S.I.o. & $\begin{array}{c}\text { RUN } \\
\text { DEL'TA }\end{array}$ & $\begin{array}{l}\text { BOTrLEE } \\
\text { DIC }\end{array}$ & $\begin{array}{l}\text { BOTTLE } \\
\text { DELTA }\end{array}$ & $\begin{array}{l}\text { "NISKIN" } \\
\text { AVG }\end{array}$ & $\begin{array}{l}\text { WHOI } \\
\text { DIC }\end{array}$ & $\begin{array}{c}\text { WHOI } \\
\text {-S.I.O. }\end{array}$ \\
\hline \multirow[t]{2}{*}{$\frac{1}{26}$} & $\begin{array}{r}30-2 \mathrm{~N} \\
134-57 \mathrm{~W}\end{array}$ & 22 & 22 & 2007 & 11JUN91 & $\begin{array}{l}\text { 25SEP91 } \\
\text { 26SEP91 }\end{array}$ & $\begin{array}{l}\text { 26SEP91 } \\
26 \text { SEP91 }\end{array}$ & $\begin{array}{l}\mathbf{s} \\
\mathrm{s}\end{array}$ & 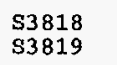 & $\begin{array}{l}001 \\
001\end{array}$ & & $\begin{array}{l}2366.87 \\
2372.19\end{array}$ & & $\begin{array}{l}2366.87 \\
2372.19\end{array}$ & +5.32 & 2369.53 & 2366.7 & -2.83 \\
\hline & & 22 & 27 & 3000 & & $\begin{array}{l}\text { 25SEP91 } \\
\text { 25SEP91 }\end{array}$ & $\begin{array}{l}\text { 26SEP91 } \\
26 \text { SEP91 }\end{array}$ & $\begin{array}{l}S \\
S\end{array}$ & $\begin{array}{l}\text { S3816 } \\
\text { S3817 }\end{array}$ & $\begin{array}{l}001 \\
001\end{array}$ & & $\begin{array}{l}2356.27 \\
2356.34\end{array}$ & & $\begin{array}{l}2356.27 \\
2356.34\end{array}$ & +0.07 & 2356.31 & 2355.6 & -0.71 \\
\hline \multirow[t]{2}{*}{$\begin{array}{l}1 \\
29\end{array}$} & $\begin{array}{r}28-30 \mathrm{~N} \\
135-00 \mathrm{~W}\end{array}$ & 1 & 1 & 1 & $12 \operatorname{JUN} 91$ & $\begin{array}{l}\text { 20AUG91 } \\
\text { 20AUG91 }\end{array}$ & $\begin{array}{l}\text { 22AUG91 } \\
\text { 22AUG91 }\end{array}$ & $\begin{array}{l}\mathbf{s} \\
\mathrm{s}\end{array}$ & $\begin{array}{l}\text { R4482 } \\
\text { R4483 }\end{array}$ & $\begin{array}{l}001 \\
001\end{array}$ & & $\begin{array}{l}2021.52 \\
2022.63\end{array}$ & & $\begin{array}{l}2021.52 \\
2022.63\end{array}$ & +1.11 & 2022.08 & 2020.5 & -1.58 \\
\hline & & 13 & 31 & 2951 & & $\begin{array}{l}\text { 20AUG91 } \\
\text { 20AUG91 }\end{array}$ & $\begin{array}{l}\text { 22AUG91 } \\
\text { 22AUG91 }\end{array}$ & $\begin{array}{l}S \\
S\end{array}$ & $\begin{array}{l}\text { R4480 } \\
\text { R4481 }\end{array}$ & $\begin{array}{l}001 \\
001\end{array}$ & & $\begin{array}{l}2382.18 \\
2378.02\end{array}$ & & $\begin{array}{l}2382.18 \\
2378.02\end{array}$ & -4.16 & 2380.10 & 2349.5 & -30.60 \\
\hline \multirow[t]{2}{*}{$\begin{array}{l}1 \\
47\end{array}$} & $\begin{array}{r}19-30 \mathrm{~N} \\
135-\mathrm{OW}\end{array}$ & 1 & 1 & 0 & 18JUN91 & $\begin{array}{l}\text { 10SEP91 } \\
\text { 10SEP91 }\end{array}$ & $\begin{array}{l}\text { 12SEP91 } \\
\text { 13SEP91 }\end{array}$ & $\begin{array}{l}\mathrm{S} \\
\mathrm{s}\end{array}$ & $\begin{array}{l}\text { R4486 } \\
\text { R4487 }\end{array}$ & $\begin{array}{l}001 \\
001\end{array}$ & & $\begin{array}{l}1979.78 \\
1979.01\end{array}$ & & $\begin{array}{l}1979.78 \\
1979.01\end{array}$ & -0.77 & 1979.40 & 1976.7 & -2.70 \\
\hline & & 12 & 27 & 3005 & & $\begin{array}{l}\text { 10SEP91 } \\
\text { 10SEP91 }\end{array}$ & $\begin{array}{l}\text { 12SEP91 } \\
\text { 12SEP91 }\end{array}$ & $\begin{array}{l}S \\
S\end{array}$ & $\begin{array}{l}\text { S3884 } \\
\text { S3885 }\end{array}$ & $\begin{array}{l}001 \\
001\end{array}$ & & $\begin{array}{l}2350.86 \\
2351.54\end{array}$ & & $\begin{array}{l}2350.86 \\
2351.54\end{array}$ & +0.68 & 2351.20 & 2342.6 & -8.60 \\
\hline \multirow[t]{2}{*}{$\begin{array}{l}1 \\
50\end{array}$} & $\begin{array}{r}18-\text { ON } \\
135-\text { OW }\end{array}$ & 1 & 1 & 0 & 19JUN9 1 & $\begin{array}{l}\text { 11SEP91 } \\
\text { 11SEP91 }\end{array}$ & $\begin{array}{l}\text { 13SEP91 } \\
\text { 13SEP91 }\end{array}$ & $\begin{array}{l}s \\
s\end{array}$ & $\begin{array}{l}\text { R4490 } \\
\text { R4491 }\end{array}$ & $\begin{array}{l}001 \\
001\end{array}$ & & $\begin{array}{l}1950.81 \\
1951.11\end{array}$ & & $\begin{array}{l}1950.81 \\
1951.11\end{array}$ & +0.30 & 1950.96 & 1947.8 & -3.16 \\
\hline & & 12 & 27 & 2999 & & 11SEP91 & 13SEP91 & $\mathbf{s}$ & R4488 & 001 & & 2368.76 & & 2368.76 & & 2368.76 & 2347.1 & -21.66 \\
\hline \multirow[t]{6}{*}{$\begin{array}{l}1 \\
53\end{array}$} & $\begin{array}{r}16-30 \mathrm{~N} \\
135-0 \mathrm{~W}\end{array}$ & 1 & 1 & 0 & 20 JUN9 1 & $\begin{array}{l}\text { 020CT91 } \\
\text { 040CT91 }\end{array}$ & $\begin{array}{l}020 \text { CT91 } \\
100 C \mathrm{CT} 91\end{array}$ & 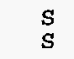 & $\begin{array}{l}\$ 3894 \\
\text { S3895 }\end{array}$ & $\begin{array}{l}001 \\
001\end{array}$ & & $\begin{array}{l}1944.28 \\
1946.88\end{array}$ & & $\begin{array}{l}1944.28 \\
1946.88\end{array}$ & +2.60 & 1945.58 & 1945.0 & -0.58 \\
\hline & & 1 & 2 & 50 & & $\begin{array}{l}010 \mathrm{CT} 91 \\
\text { 010СT91 }\end{array}$ & $\begin{array}{l}\text { 020CT } 91 \\
\text { 020CT91 }\end{array}$ & $\mathbf{S}$ & $\begin{array}{l}\text { S3892 } \\
\text { S3893 }\end{array}$ & $\begin{array}{l}001 \\
001\end{array}$ & & $\begin{array}{l}1944.71 \\
1943.80\end{array}$ & & $\begin{array}{l}1944.71 \\
1943.80\end{array}$ & -0.91 & 1944.26 & 1943.7 & -0.56 \\
\hline & & 1 & 4 & 112 & & $\begin{array}{l}\text { 30SEP91 } \\
\text { 30SEP91 }\end{array}$ & $\begin{array}{l}\text { 020CT91 } \\
\text { 020CT91 }\end{array}$ & $\begin{array}{l}\mathbf{S} \\
\mathbf{S}\end{array}$ & $\begin{array}{l}\$ 3890 \\
\text { S3891 }\end{array}$ & $\begin{array}{l}001 \\
001\end{array}$ & & $\begin{array}{l}2018.80 \\
2018.45\end{array}$ & & $\begin{array}{l}2018.80 \\
2018.45\end{array}$ & -0.35 & 2018.63 & 2017.3 & -1.33 \\
\hline & & 1 & 8 & 188 & & $\begin{array}{l}\text { 30SEP91 } \\
30 \text { SEP91 }\end{array}$ & $\begin{array}{l}020 C \mathrm{CP} 91 \\
\text { 020CT } 91\end{array}$ & $\begin{array}{l}S \\
S\end{array}$ & $\begin{array}{l}\$ 3888 \\
\text { S3889 }\end{array}$ & $\begin{array}{l}001 \\
001\end{array}$ & & $\begin{array}{l}2159.93 \\
2160.18\end{array}$ & & $\begin{array}{l}2159.93 \\
2160.18\end{array}$ & +0.25 & 2160.05 & 2159.1 & -0.95 \\
\hline & & 11 & 10 & 300 & & $\begin{array}{l}\text { 26SEP91 } \\
\text { 27SEP91 }\end{array}$ & $\begin{array}{l}020 \mathrm{cr} 91 \\
020 \mathrm{Cr} 91\end{array}$ & $\begin{array}{l}\mathrm{s} \\
\mathrm{s}\end{array}$ & $\begin{array}{l}\$ 3886 \\
\$ 3887\end{array}$ & $\begin{array}{l}001 \\
001\end{array}$ & & $\begin{array}{l}2261.14 \\
2260.40\end{array}$ & & $\begin{array}{l}2261.14 \\
2260.40\end{array}$ & -0.74 & 2260.77 & 2259.3 & -1.47 \\
\hline & & 11 & 12 & 402 & & $\begin{array}{l}\text { 19SEP91 } \\
\text { 19SEP91 }\end{array}$ & $\begin{array}{l}\text { 20SEP91 } \\
\text { 20SEP91 }\end{array}$ & $\begin{array}{l}\mathbf{S} \\
\mathbf{S}\end{array}$ & $\begin{array}{l}R 4504 \\
R 4505\end{array}$ & $\begin{array}{l}001 \\
001\end{array}$ & & $\begin{array}{l}2287.13 \\
2284.44\end{array}$ & & $\begin{array}{l}2287.13 \\
2284.44\end{array}$ & -2.69 & 2285.78 & 2281.5 & -4.28 \\
\hline
\end{tabular}


Table 1 (continued)

THE CARBON DIOXIDE PROJECT OF THE SCRIPPS INSTITUTION OF OCEANOGRAPHY TUNES Leg 11991 Pacific WOCE Line P17C

SUMMARY OF DISSOLVED INORGANIC CARBON DATA (cont)

\begin{tabular}{|c|c|c|c|c|c|c|c|c|c|c|c|c|c|c|c|c|c|}
\hline LEG & LAT & CAST & DEPTH & SAMPLE & EXTRAC & ANALYSIS & MANO & SAMPLE & & & $\underset{\text { RUN }}{\text { S.x.o. }}$ & $\begin{array}{c}\text { RUN } \\
\text { DELTA }\end{array}$ & $\begin{array}{l}\text { BOTrLE } \\
\text { DIC }\end{array}$ & $\begin{array}{c}\text { BOTTLE } \\
\text { DELTA }\end{array}$ & $\begin{array}{l}\text { "NISKIN" } \\
\text { AVG }\end{array}$ & $\begin{array}{l}\text { WHOI } \\
\text { DIC }\end{array}$ & $\begin{array}{r}\text { WHOI } \\
\text {-S.I.O. }\end{array}$ \\
\hline \multirow[t]{6}{*}{$\begin{array}{l}1 \\
53\end{array}$} & $\begin{array}{r}16-30 \mathrm{~N} \\
135-\mathrm{OW}\end{array}$ & 11 & $4 \quad 597$ & 20JUN91 & $\begin{array}{l}\text { 18SEP91 } \\
\text { 18SEP91 }\end{array}$ & $\begin{array}{l}\text { 20SEP91 } \\
20 \text { SEP91 }\end{array}$ & $\begin{array}{l}\mathrm{S} \\
\mathrm{S}\end{array}$ & $\begin{array}{l}\text { R4502 } \\
\text { R4503 }\end{array}$ & $\begin{array}{l}001 \\
001\end{array}$ & & $\begin{array}{l}2314.33 \\
2316.53\end{array}$ & & $\begin{array}{l}2314.33 \\
2316.53\end{array}$ & +2.20 & 2315.43 & 2306.8 & -8.63 \\
\hline & & 11 & $7 \quad 904$ & & $\begin{array}{l}\text { 17SEP91 } \\
\text { 17SEP91 }\end{array}$ & $\begin{array}{l}\text { 20SEP91 } \\
\text { 20SEP91 }\end{array}$ & $\begin{array}{l}\mathbf{S} \\
\mathbf{S}\end{array}$ & $\begin{array}{l}\text { R4500 } \\
\text { R4501 }\end{array}$ & $\begin{array}{l}001 \\
001\end{array}$ & & $\begin{array}{l}2343.16 \\
2342.63\end{array}$ & & $\begin{array}{l}2343.16 \\
2342.63\end{array}$ & -0.53 & 2342.90 & 2337.4 & -5.50 \\
\hline & & 11 & 91.205 & & $\begin{array}{l}\text { 16SEP91 } \\
17 \text { SEP91 }\end{array}$ & $\begin{array}{l}\text { 20SEP91 } \\
\text { 20SEP91 }\end{array}$ & $\begin{array}{l}\mathrm{s} \\
\mathrm{s}\end{array}$ & $\begin{array}{l}R 4498 \\
R 4499\end{array}$ & $\begin{array}{l}001 \\
001\end{array}$ & & $\begin{array}{r}2360.09 \\
2359.18\end{array}$ & & $\begin{array}{l}2360.09 \\
2359.18\end{array}$ & -0.91 & 2359.64 & 2350.7 & -8.94 \\
\hline & & 12 & 11602 & & 13SEP91 & 13SEP91 & $s$ & R4496 & 001 & & 2369.00 & & 2369.00 & & 2369.00 & 2359.2 & -9.80 \\
\hline & & 12 & 32008 & & $\begin{array}{l}\text { 13SEP91 } \\
13 \text { SEP91 }\end{array}$ & $\begin{array}{l}\text { 13SEP91 } \\
\text { 13SEP91 }\end{array}$ & $\begin{array}{l}\mathrm{S} \\
\mathrm{S}\end{array}$ & $\begin{array}{l}\text { R4494 } \\
\text { R4495 }\end{array}$ & $\begin{array}{l}001 \\
001\end{array}$ & & $\begin{array}{l}2368.43 \\
2367.86\end{array}$ & & $\begin{array}{l}2368.43 \\
2367.86\end{array}$ & -0.57 & 2368.15 & & \\
\hline & & 12 & 83000 & & $\begin{array}{l}\text { 12SEP91 } \\
\text { 13SEP91 }\end{array}$ & $\begin{array}{l}\text { 13SEP91 } \\
13 \text { SEP91 }\end{array}$ & $\begin{array}{l}\mathrm{s} \\
\mathrm{S}\end{array}$ & $\begin{array}{l}\text { R4492 } \\
\text { R4493 }\end{array}$ & $\begin{array}{l}001 \\
001\end{array}$ & & $\begin{array}{l}2357.88 \\
2353.83\end{array}$ & & $\begin{array}{l}2357.88 \\
2353.83\end{array}$ & -4.05 & 2355.85 & 2349.2 & -6.65 \\
\hline \multirow[t]{2}{*}{$\begin{array}{l}1 \\
74\end{array}$} & $\begin{array}{r}6-\text { ON } \\
135-00 \mathrm{~W}\end{array}$ & 1 & -1 & 26JUN91 & $\begin{array}{l}05 \mathrm{DEC} 91 \\
05 \mathrm{DEC} 91 \\
05 \mathrm{DEC} 91 \\
05 \mathrm{DEC} 91\end{array}$ & $\begin{array}{l}05 \text { DEC } 91 \\
12 \text { DEC } 91 \\
06 \text { DEC } 91 \\
12 \text { DEC } 91\end{array}$ & $\begin{array}{l}M \\
S \\
M \\
S\end{array}$ & $\begin{array}{l}\text { R4522 } \\
R 4522 \\
R 4523 \\
\text { R4523 }\end{array}$ & $\begin{array}{l}001 \\
001 \\
001 \\
001\end{array}$ & & $\begin{array}{l}1914.53 \\
1915.16 \\
1916.39 \\
1916.71\end{array}$ & & $\begin{array}{l}1914.53 \\
1915.16 \\
1916.39 \\
1916.71\end{array}$ & $\begin{array}{l}+1.86 \\
+1.55\end{array}$ & $\begin{array}{l}1915.46 \\
1915.94\end{array}$ & $\begin{array}{l}1915.8 \\
1915.8\end{array}$ & $\begin{array}{r}0.34 \\
-0.14\end{array}$ \\
\hline & & 12 & 92992 & & $\begin{array}{l}\text { 05DEC91 } \\
\text { 05DEC91 } \\
05 D E C 91 \\
\text { 05DEC91 }\end{array}$ & $\begin{array}{l}\text { 05DEC91 } \\
\text { 09DEC91 } \\
\text { 05DEC91 } \\
\text { 09DEC91 }\end{array}$ & $\begin{array}{l}M \\
S \\
M \\
S\end{array}$ & $\begin{array}{l}\text { R4520 } \\
\text { R4520 } \\
\text { R4521 } \\
\text { R4521 }\end{array}$ & $\begin{array}{l}001 \\
001 \\
001 \\
001\end{array}$ & & $\begin{array}{l}2353.96 \\
2353.74 \\
2354.24 \\
2354.81\end{array}$ & & $\begin{array}{l}2353.96 \\
2353.74 \\
2354.24 \\
2354.81\end{array}$ & $\begin{array}{l}+0.28 \\
+1.07\end{array}$ & $\begin{array}{l}2354.10 \\
2354.28\end{array}$ & $\begin{array}{l}2358.3 \\
2358.3\end{array}$ & $\begin{array}{l}4.20 \\
4.02\end{array}$ \\
\hline \multirow[t]{2}{*}{$\begin{array}{c}1 \\
104\end{array}$} & $\begin{array}{r}1-00 S \\
135-0 W\end{array}$ & 1 & 0 & 03JUL91 & $\begin{array}{l}\text { 09DEC91 } \\
\text { 09DEC91 } \\
09 D E C 91 \\
09 D E C 91\end{array}$ & $\begin{array}{l}10 \text { DEC } 91 \\
13 \text { DEC } 91 \\
100 E C 91 \\
13 \text { DEC } 91\end{array}$ & $\begin{array}{l}\mathrm{M} \\
\mathrm{S} \\
\mathrm{M} \\
\mathrm{S}\end{array}$ & $\begin{array}{l}\text { S3986 } \\
\text { S3986 } \\
\text { S3987 } \\
\text { S3987 }\end{array}$ & $\begin{array}{l}001 \\
001 \\
001 \\
001\end{array}$ & & $\begin{array}{l}2017.01 \\
2017.31 \\
2016.77 \\
2016.76\end{array}$ & & $\begin{array}{l}2017.01 \\
2017.31 \\
2016.77 \\
2016.76\end{array}$ & $\begin{array}{l}-0.24 \\
-0.55\end{array}$ & $\begin{array}{l}2016.89 \\
2017.04\end{array}$ & $\begin{array}{l}2015.6 \\
2015.6\end{array}$ & $\begin{array}{l}-1.29 \\
-1.44\end{array}$ \\
\hline & & 130 & 02999 & & $\begin{array}{l}\text { 06DEC91 } \\
\text { 06DEC91 } \\
06 \mathrm{DEC} 91 \\
\text { 06DEC } 91\end{array}$ & $\begin{array}{l}06 \mathrm{DEC} 91 \\
12 \mathrm{DEC} 91 \\
06 \mathrm{DEC} 91 \\
12 \mathrm{DEC} 91\end{array}$ & $\begin{array}{l}M \\
S \\
M \\
S\end{array}$ & $\begin{array}{l}\text { R4544 } \\
\text { R4544 } \\
\text { R4545 } \\
\text { R4545 }\end{array}$ & $\begin{array}{l}001 \\
001 \\
001 \\
001\end{array}$ & & $\begin{array}{l}2340.10 \\
2339.57 \\
2342.51 \\
2342.36\end{array}$ & & $\begin{array}{l}2340.10 \\
2339.57 \\
2342.51 \\
2342.36\end{array}$ & $\begin{array}{l}+2.41 \\
+2.79\end{array}$ & $\begin{array}{l}2341.31 \\
2340.97\end{array}$ & $\begin{array}{l}2334.5 \\
2334.5\end{array}$ & $\begin{array}{l}-6.81 \\
-6.47\end{array}$ \\
\hline$\frac{1}{110}$ & $\begin{array}{r}1-585 \\
135-0 W\end{array}$ & 13 & $0 \quad 2998$ & 04JUL91 & $\begin{array}{l}06 \text { DEC } 91 \\
06 \text { DEC } 91 \\
06 \text { DEC } 91 \\
06 \text { DEC } 91\end{array}$ & $\begin{array}{l}06 \mathrm{DEC} 91 \\
12 \mathrm{DEC} 91 \\
06 \mathrm{DEC} 91 \\
12 \mathrm{DEC} 91\end{array}$ & $\begin{array}{l}M \\
S \\
M \\
S\end{array}$ & $\begin{array}{l}\text { S3988 } \\
\text { S3988 } \\
\text { S3989 } \\
\text { S3989 }\end{array}$ & $\begin{array}{l}001 \\
001 \\
001 \\
001\end{array}$ & & $\begin{array}{l}2332.03 \\
2331.71 \\
2331.95 \\
2332.40\end{array}$ & & $\begin{array}{l}2332.03 \\
2331.71 \\
2331.95 \\
2332.40\end{array}$ & $\begin{array}{l}-0.08 \\
+0.69\end{array}$ & $\begin{array}{l}2331.99 \\
2332.05\end{array}$ & $\begin{array}{l}2330.2 \\
2330.2\end{array}$ & $\begin{array}{l}-1.79 \\
-1.85\end{array}$ \\
\hline $\begin{aligned} \text { MANOME } & \\
S & = \\
M & = \\
\text { BOTTLE } & \\
R & =\end{aligned}$ & $\begin{array}{l}\text { ETER TYPE } \\
\text { QUARTZ } \\
\text { CONSTANI } \\
\text { E TYPE: } \\
=\text { RODDAVIS }\end{array}$ & ss & $\mathrm{s}$ & TYI & OM & & & & $\begin{array}{r}\text { FLAG } \\
\text { F: } \\
\text { G: } \\
\text { EX: }\end{array}$ & & ded & & & & & & \\
\hline
\end{tabular}


Table 1 (continued)

THE CARBON DIOXIDE PROJECT OF THE SCRIPPS INSTITUTION OF OCEANOGRAPHY TUNES Leg 11991 Pacific WOCE Line P17C

SUMMARY OF DISSOLVED INORGANIC CARBON DATA (cont)

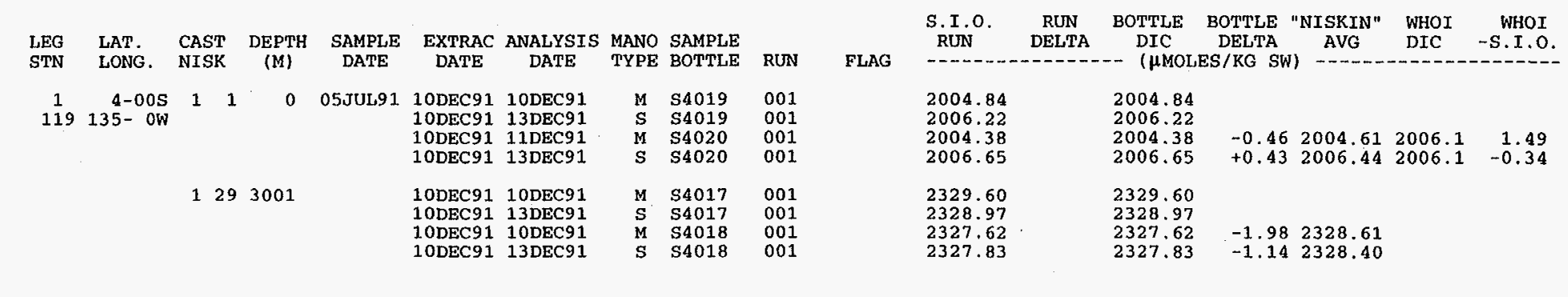

MANOMETER TYPE:

FLAGS:

$S=$ QUARTZ SPIRAL MANOMETER DATUM

$F$ : No Hg found in bottle

$M=$ CONSTANT VOLUME MERCURY MANOMETER DATUM

G; Severe bottle leak

BOTTLE TYPE:
$\mathbf{R}=$ RODAVISS

$$
\mathbf{S}=\mathbf{S} \text { TYPE }
$$

Ex: Data excluded from analysis

NOTE: Dilution factor of 1.000170 has been applied. 
Table 2. Summary of TALK replicate data collected during R/V Thomas Washingion TUNES-1 Expedition THE CARBON DIOXIDE PROJECT OF THE SCRTPPS INSTITUTION OF OCEANOGRAPHY TUNES Leg 11991 Pacific WOCE Line P17C

SUMMARY OF ALKALINITY DATA

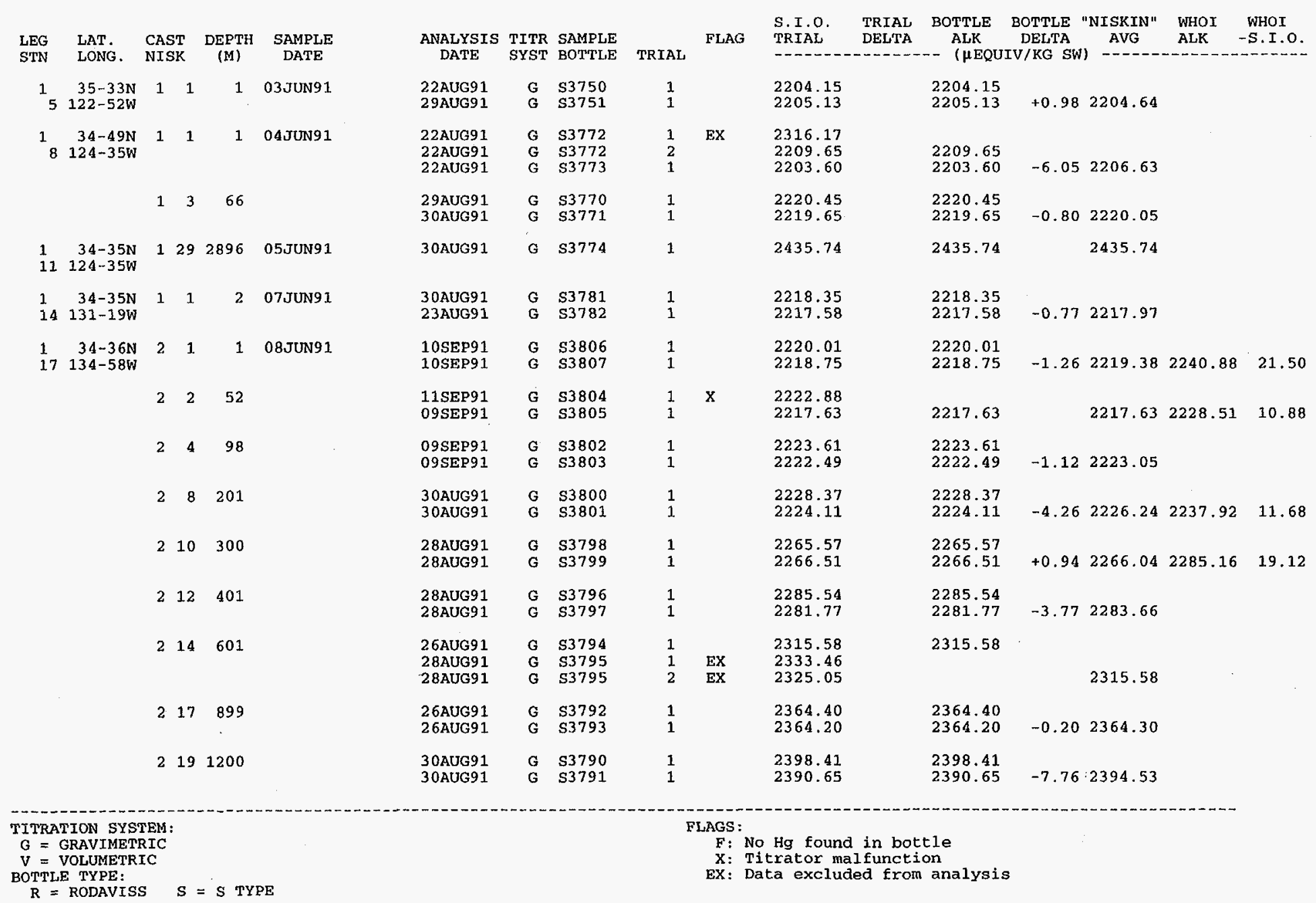


Table 2 (continued)

THE CARBON DIOXIDE PROJECT OF THE SCRIPPS INSTITUTION OF OCEANOGRAPHY TUNES Leg 1 1991 Pacific WOCE Line P17C

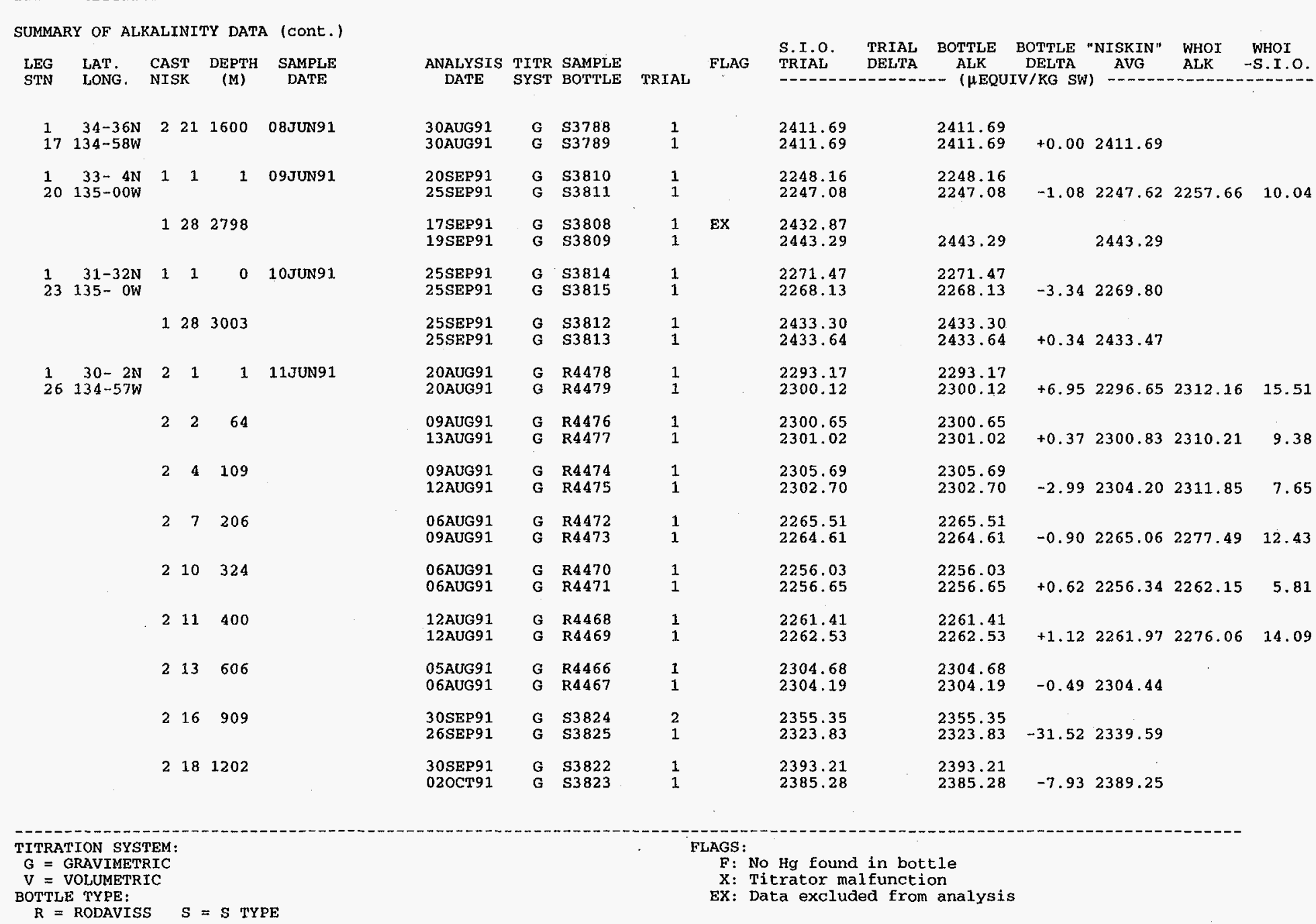


Table 2 (continued)

THE CARBON DIOXIDE PROJECT OF THE SCRIPPS INSTITUTION OF OCEANOGRAPHY TUNES Leg 11991 pacific WOCE Line P17C

SUMMARY OF ALKALINITY DATA (cont.)

\begin{tabular}{|c|c|c|c|c|c|c|c|c|c|c|c|c|c|c|c|c|}
\hline LEG & LAT. & CAST & DEPTH & SAMPLE & ANALYSIS & TITR & SAMPLE & & FLAG & $\begin{array}{l}\text { S.I.O. } \\
\text { TRIAL }\end{array}$ & $\begin{array}{l}\text { TRIAL } \\
\text { DELTA }\end{array}$ & $\begin{array}{l}\text { BOTTLE } \\
\text { ALK }\end{array}$ & $\begin{array}{c}\text { BOTTLE } \\
\text { DELTA }\end{array}$ & $\begin{array}{c}\text { "NISKIN" } \\
\text { AVG }\end{array}$ & $\begin{array}{l}\text { WHOI } \\
\text { ALK }\end{array}$ & $\begin{array}{l}\text { WHOI } \\
\text {-S.I.O. }\end{array}$ \\
\hline STN & LONG. & NISK & (M) & DATE & DATE & SYST & BOTTLE & TRIAL & & & & $\cdots \quad(\mu$ EQUI & $\mathrm{IV} / \mathrm{KG} \quad \mathrm{SW})$ & 1) $-\ldots$ & & \\
\hline \multirow[t]{3}{*}{$\begin{array}{l}1 \\
26\end{array}$} & $\begin{array}{r}30-2 \mathrm{~N} \\
134-57 \mathrm{~W}\end{array}$ & 22 & 01605 & 11JUN91 & $\begin{array}{l}\text { 26SEP91 } \\
\text { 010CT91 }\end{array}$ & $\begin{array}{l}G \\
G\end{array}$ & $\begin{array}{l}\text { S3820 } \\
\text { S3821 }\end{array}$ & $\begin{array}{l}1 \\
1\end{array}$ & & $\begin{array}{l}2407.50 \\
2407.56\end{array}$ & & $\begin{array}{l}2407.50 \\
2407.56\end{array}$ & +0.06 & 2407.53 & & \\
\hline & & 22 & 22007 & & $\begin{array}{l}\text { 020CT91 } \\
\text { 26SEP91 }\end{array}$ & $\begin{array}{l}\text { G } \\
\mathbf{G}\end{array}$ & $\begin{array}{l}\text { S3818 } \\
\text { S3819 }\end{array}$ & $\begin{array}{l}1 \\
1\end{array}$ & & $\begin{array}{l}2414.88 \\
2417.05\end{array}$ & & $\begin{array}{l}2414.88 \\
2417.05\end{array}$ & +2.17 & 2415.97 & & \\
\hline & & 22 & 73000 & & $\begin{array}{l}\text { 25SEP91 } \\
\text { 25SEP91 }\end{array}$ & $\begin{array}{l}\text { G } \\
G\end{array}$ & $\begin{array}{l}\text { S3816 } \\
\text { S3817 }\end{array}$ & $\begin{array}{l}1 \\
1\end{array}$ & & $\begin{array}{l}2439.46 \\
2432.16\end{array}$ & & $\begin{array}{l}2439.46 \\
2432.16\end{array}$ & -7.30 & 2435.81 & & \\
\hline \multirow[t]{2}{*}{$\frac{1}{29}$} & $\begin{array}{r}28-30 \mathrm{~N} \\
135-00 \mathrm{~W}\end{array}$ & 1 & 1 & $12 J$ UN9 91 & $\begin{array}{l}\text { 21AUG91 } \\
\text { 21AUG91 }\end{array}$ & $\begin{array}{l}\text { G } \\
\text { G }\end{array}$ & $\begin{array}{l}\text { R4482 } \\
\text { R4483 }\end{array}$ & $\begin{array}{l}1 \\
1\end{array}$ & & $\begin{array}{l}2294.95 \\
2290.86\end{array}$ & & $\begin{array}{l}2294.95 \\
2290.86\end{array}$ & -4.09 & 2292.91 & 2306.02 & 13.11 \\
\hline & & 13 & 12951 & & $\begin{array}{l}\text { 20AUG91 } \\
\text { 20AUG91 } \\
\text { 21AUG91 }\end{array}$ & $\begin{array}{l}G \\
G \\
G\end{array}$ & $\begin{array}{l}\text { R4480 } \\
\text { R4481 } \\
\text { R4481 }\end{array}$ & $\begin{array}{l}1 \\
1 \\
2\end{array}$ & $\mathrm{x}$ & $\begin{array}{l}2442.89 \\
2432.56 \\
2435.40\end{array}$ & & $\begin{array}{l}2442.89 \\
2435.40\end{array}$ & -7.49 & 2439.15 & & \\
\hline \multirow[t]{2}{*}{$\begin{array}{l}1 \\
47\end{array}$} & $\begin{array}{r}19-30 \mathrm{~N} \\
135-\mathrm{OW}\end{array}$ & 1 & 0 & 18JUN91 & $\begin{array}{l}\text { 10SEP91 } \\
\text { 10SEP91 }\end{array}$ & $\begin{array}{l}G \\
G\end{array}$ & $\begin{array}{l}\text { R4486 } \\
\text { R4487 }\end{array}$ & $\begin{array}{l}1 \\
1\end{array}$ & & $\begin{array}{r}2290.66 \\
2294.47\end{array}$ & & $\begin{array}{r}2290.66 \\
2294.47\end{array}$ & +3.81 & 2292.56 & 2298.90 & 6.34 \\
\hline & & 12 & 73005 & & $\begin{array}{l}\text { 10SEP91 } \\
\text { 10SEP91 }\end{array}$ & $\begin{array}{l}G \\
G\end{array}$ & $\begin{array}{l}\text { S3884 } \\
\text { S3885 }\end{array}$ & $\begin{array}{l}1 \\
1\end{array}$ & & $\begin{array}{l}2435.33 \\
2434.26\end{array}$ & & $\begin{array}{l}2435.33 \\
2434.26\end{array}$ & -1.07 & 2434.80 & & \\
\hline \multirow[t]{2}{*}{$\begin{array}{l}1 \\
50\end{array}$} & $\begin{array}{r}18-\text { ON } \\
135-\text { OW }\end{array}$ & 1 & 0 & 19JUN91 & $\begin{array}{l}\text { 11SEP91 } \\
11 \text { SEP91 }\end{array}$ & $\begin{array}{l}G \\
G\end{array}$ & $\begin{array}{l}\mathrm{R} 4490 \\
\mathrm{R} 4491\end{array}$ & 1 & & $\begin{array}{l}2269.78 \\
2277.37\end{array}$ & & $\begin{array}{l}2269.78 \\
2277.37\end{array}$ & +7.59 & 2273.58 & 2282.90 & 9.32 \\
\hline & & 12 & 72999 & & $\begin{array}{l}\text { 11SEP91 } \\
\text { 12SEP91 }\end{array}$ & $\begin{array}{l}G \\
G\end{array}$ & $\begin{array}{l}\text { R4488 } \\
\text { R4489 }\end{array}$ & $\begin{array}{l}1 \\
1\end{array}$ & & $\begin{array}{r}2396.89 \\
2393.93\end{array}$ & & $\begin{array}{l}2396.89 \\
2393.93\end{array}$ & -2.96 & 2395.41 & & \\
\hline \multirow[t]{6}{*}{$\begin{array}{l}1 \\
53\end{array}$} & $\begin{array}{r}16-30 \mathrm{~N} \\
135-\mathrm{OW}\end{array}$ & 1. & 0 & 20JUN91 & $\begin{array}{l}230 \mathrm{CT} 91 \\
\text { 230Ст91 }\end{array}$ & $\begin{array}{l}G \\
G\end{array}$ & $\begin{array}{l}\text { S3894 } \\
\text { S3895 }\end{array}$ & $\begin{array}{l}1 \\
1\end{array}$ & & $\begin{array}{l}2272.47 \\
2272.31\end{array}$ & & $\begin{array}{l}2272.47 \\
2272.31\end{array}$ & -0.16 & 2272.39 & 2254.90 & -17.49 \\
\hline & & 1 & 50 & & $220 \mathrm{OT} 91$ & G & $\$ 3893$ & 1 & & 2270.20 & & 2270.20 & & 2270.20 & 2286.90 & 16.70 \\
\hline & & 1 & $4 \quad 112$ & & $\begin{array}{l}\text { 020Ст91 } \\
220 \mathrm{OCT} 91\end{array}$ & $\begin{array}{l}G \\
G\end{array}$ & $\begin{array}{l}\text { S3890 } \\
\text { S3891 }\end{array}$ & 1 & & $\begin{array}{l}2294.04 \\
2298.05\end{array}$ & & $\begin{array}{l}2294.04 \\
2298.05\end{array}$ & +4.01 & 2296.05 & 2316.90 & 20.85 \\
\hline & & 1 & $\begin{array}{ll}8 & 188\end{array}$ & & $\begin{array}{l}\text { 010СT91 } \\
\text { 020СТ91 }\end{array}$ & $\begin{array}{l}G \\
G\end{array}$ & $\begin{array}{l}\text { S3888 } \\
\text { S3889 }\end{array}$ & $\begin{array}{l}1 \\
1\end{array}$ & & $\begin{array}{l}2266.82 \\
2263.21\end{array}$ & & $\begin{array}{l}2266.82 \\
2263.21\end{array}$ & -3.61 & 2265.02 & 2270.60 & 5.58 \\
\hline & & 11 & $0 \quad 300$ & & $\begin{array}{l}\text { 010СТ91 } \\
\text { 020СT91 }\end{array}$ & $\begin{array}{l}G \\
G\end{array}$ & $\begin{array}{l}\text { S3886 } \\
\text { S3887 }\end{array}$ & $\begin{array}{l}1 \\
1\end{array}$ & & $\begin{array}{l}2293.99 \\
2294.72\end{array}$ & & $\begin{array}{l}2293.99 \\
2294.72\end{array}$ & +0.73 & 2294.35 & 2300.90 & 6.55 \\
\hline & & 11 & $2 \quad 402$ & & $\begin{array}{l}\text { 19SEP91 } \\
19 \text { SEP91 }\end{array}$ & $\begin{array}{l}G \\
G\end{array}$ & $\begin{array}{l}\text { R4504 } \\
\text { R4505 }\end{array}$ & $\begin{array}{l}1 \\
1\end{array}$ & & $\begin{array}{l}2304.53 \\
2306.77\end{array}$ & & $\begin{array}{l}2304.53 \\
2306.77\end{array}$ & +2.24 & 2305.65 & 2311.00 & 5.35 \\
\hline \multicolumn{5}{|c|}{$\begin{array}{l}\text { TITRATION SYSTEM: } \\
G=\text { GRAVIMETRIC } \\
V=\text { VOLUMETRIC } \\
\text { BOTTLE TYPE: } \\
\text { R = RODAVISS }\end{array}$} & & & & & $\begin{array}{r}F: \\
X: \\
E X:\end{array}$ & exc & & inalysis & & & & \\
\hline
\end{tabular}


Table 2 (continued)

THE CARBON DIOXIDE PROJECT OF THE SCRIPPS INSTITUTION OF OCEANOGRAPHY TUNES Leg 11991 Pacific WOCE Line P17C

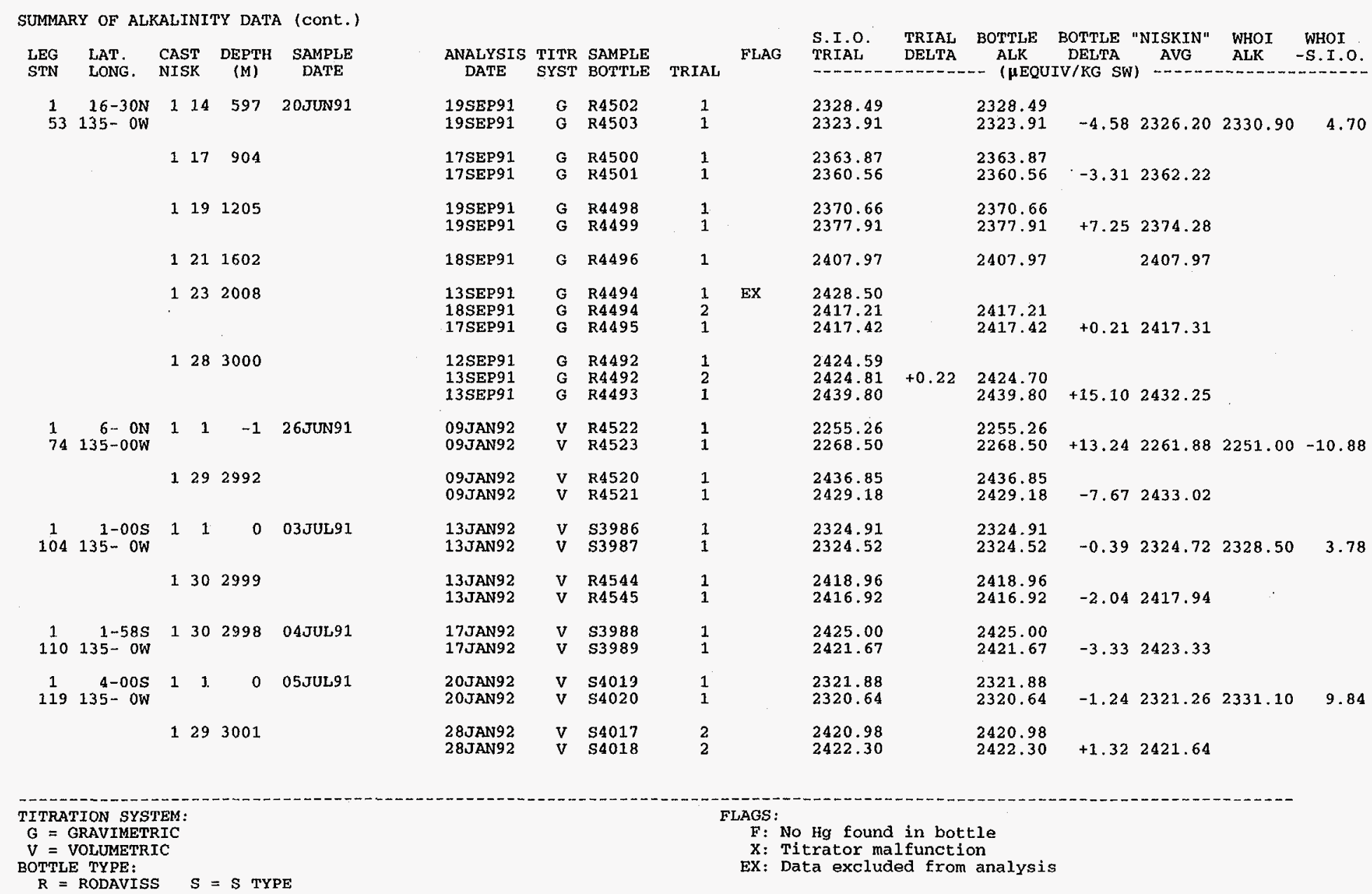

$\mathrm{R}=$ RODAVISS $S=S$ TYPE

NOTE: Dilution factor of 1.000170 has been applied. 


\section{DATA CHECKS AND PROCESSING PERFORMED BY CDIAC}

An important part of the NDP process at the Carbon Dioxide Information Analysis Center (CDIAC) involves the quality assurance (QA) review of data before distribution. To guarantee data of the highest possible quality, CDIAC conducts extensive QA reviews that involve examining the data for completeness, reasonableness, and accuracy. Although they have common objectives, these reviews are tailored to each data set and often require extensive programming efforts. In short, the QA process is a critical component in the value-added concept of supplying accurate, usable data for researchers.

The following information summarizes the data-processing and QA checks performed by CDIAC on the data obtained during the R/V Thomas Washington TUNES-1 Expedition in the South Pacific Ocean (WOCE Section P17C).

1. Carbon-related data and preliminary hydrographic measurements were provided to CDIAC by Catherine Goyet of WHOI; $\Delta^{14} \mathrm{C}$ data were contributed by Robert M. Key of Princeton University; the CFC data were contributed by Kevin F. Sullivan of Miami University. The final hydrographic measurements and the station information files were provided by the WHPO after quality evaluation. A FORTRAN 77 retrieval code was written and used to merge and reformat all data files.

2. The designation for missing values, given as " -9.0 " in the original files, was changed to "-999.9."

3. To check for obvious outliers, all data were plotted with a PLOTNEST.C program written by Stewart C. Sutherland (Lamont-Doherty Earth Observatory). The program plots a series of nested profiles, using the station number as an offset; the first station is defined at the beginning, and subsequent stations are offset by a fixed interval (Figs. 4-7). Several outliers were identified and removed after consultation with the principal investigators.

4. To identify "noisy" data and possible systematic, methodological errors, property-property plots for all parameters were generated (Fig. 8), carefully examined, and compared with plots from previous expeditions in the South Pacific Ocean.

5. Dates and times were checked for bogus values (e.g., values of MONTH $<1$ or $>12$, DAY $<1$ or $>31$, YEAR $\neq 1991$, TIME $<0000$ or $>2400$ ).

6. Station locations (latitudes and longitudes) and sampling times were examined for consistency with maps and cruise information supplied by the WHPO. 


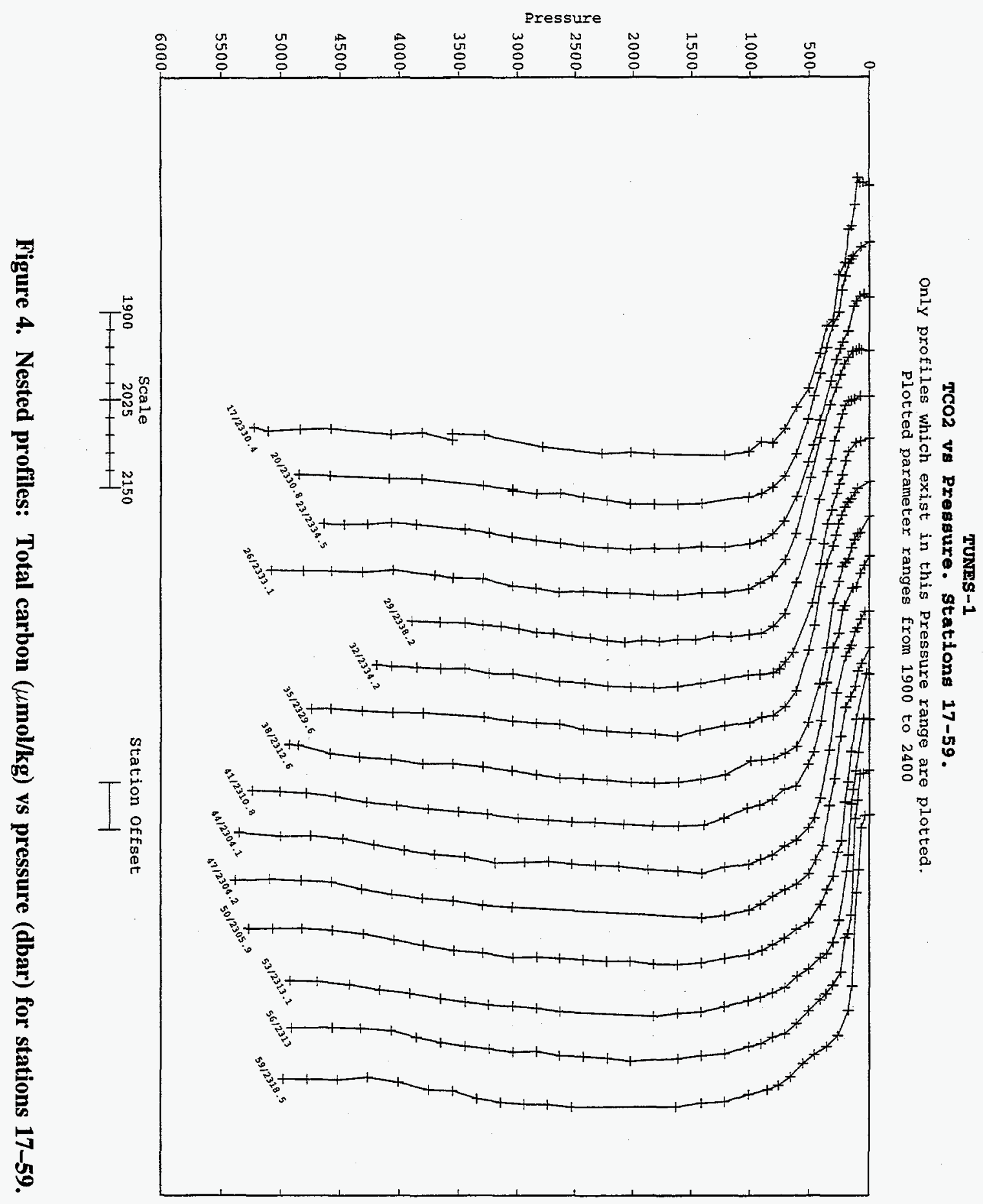




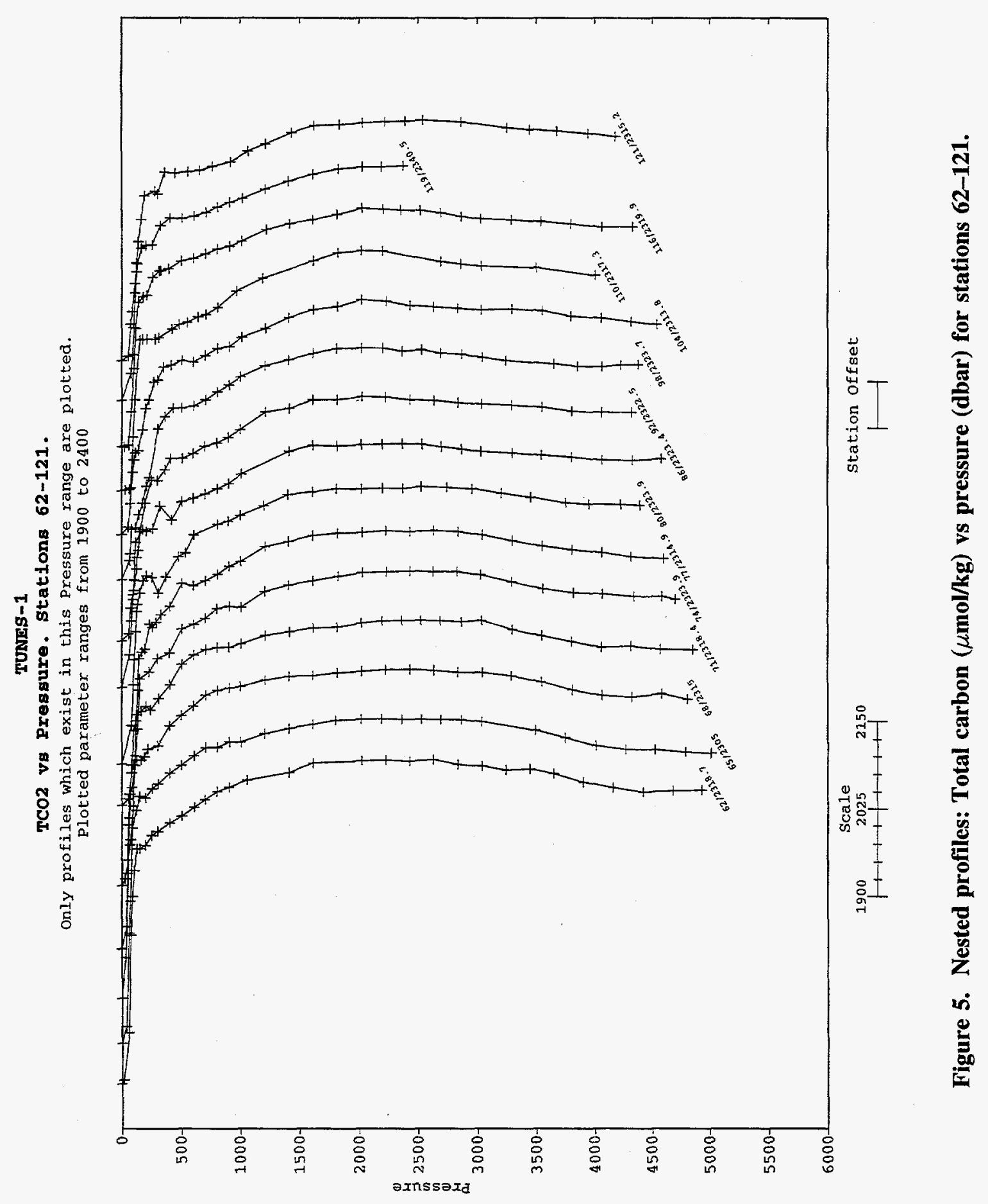




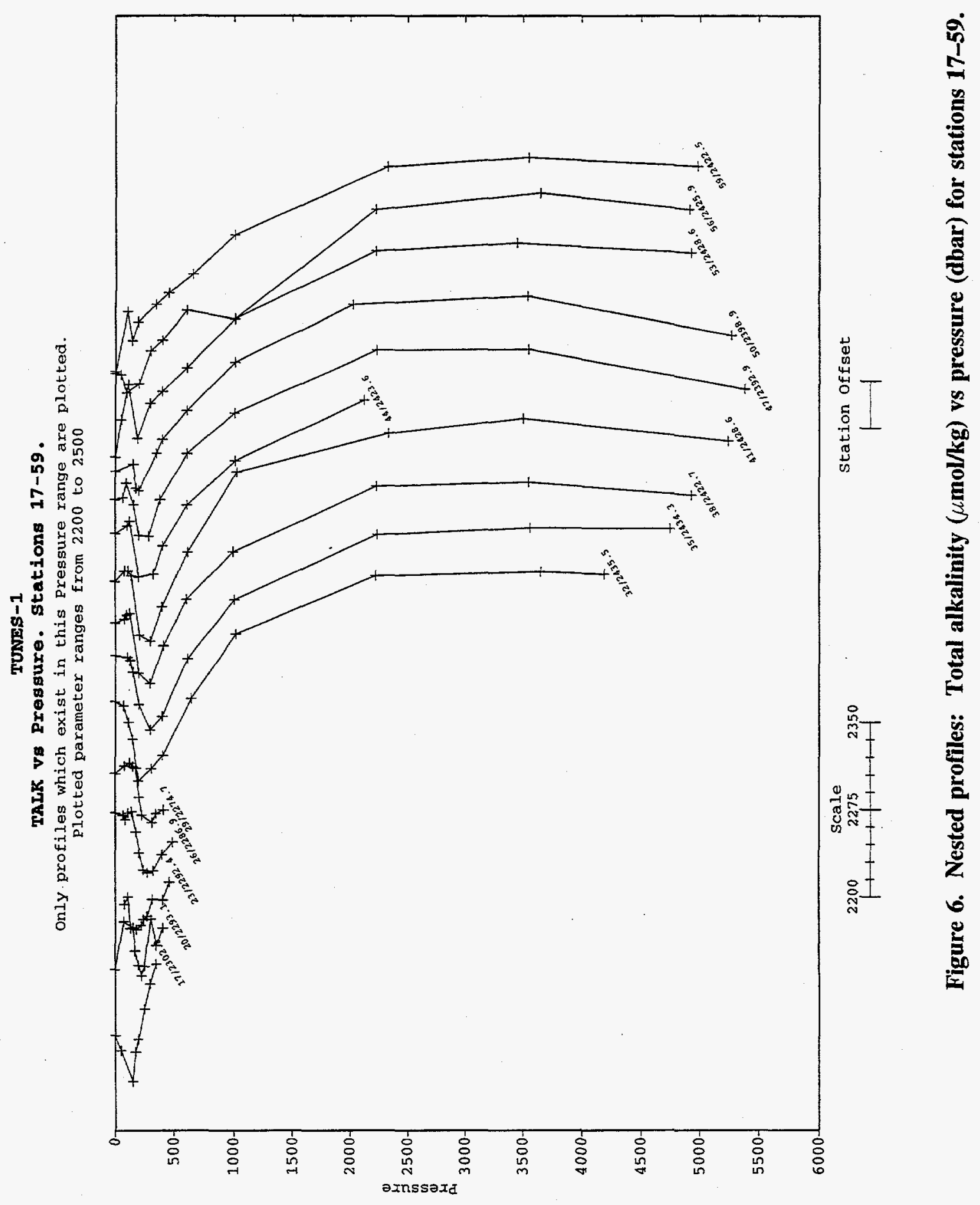


TUNES-1

TALK va Pressure. Stations 62-121.

only profiles which exist in this Pressure range are plotted. plotted parameter ranges from 2200 to 2500

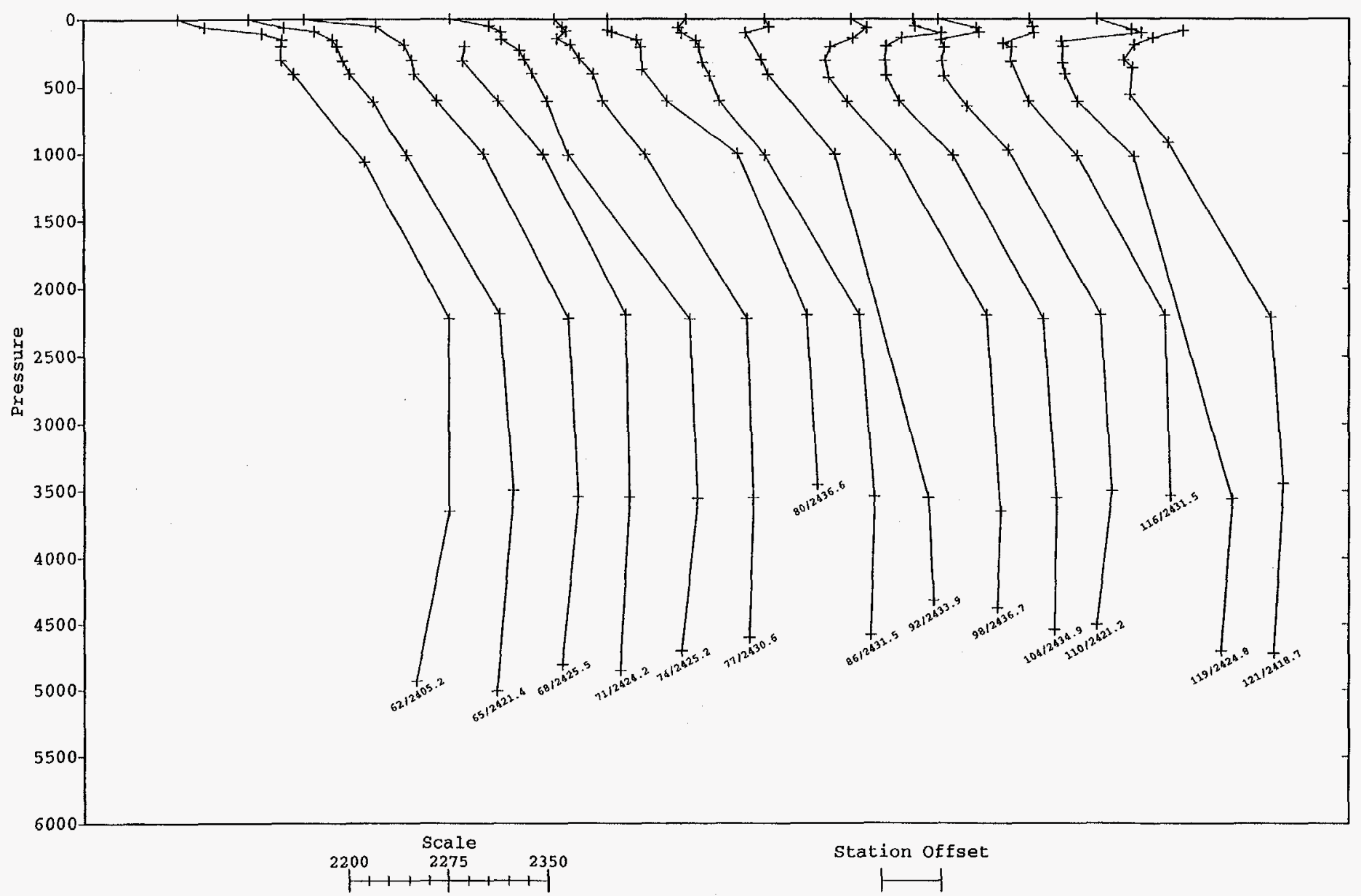

Figure 7. Nested profiles: Total alkalinity $(\mu \mathrm{mol} / \mathrm{kg})$ vs pressure (dbar) for stations 62-121. 

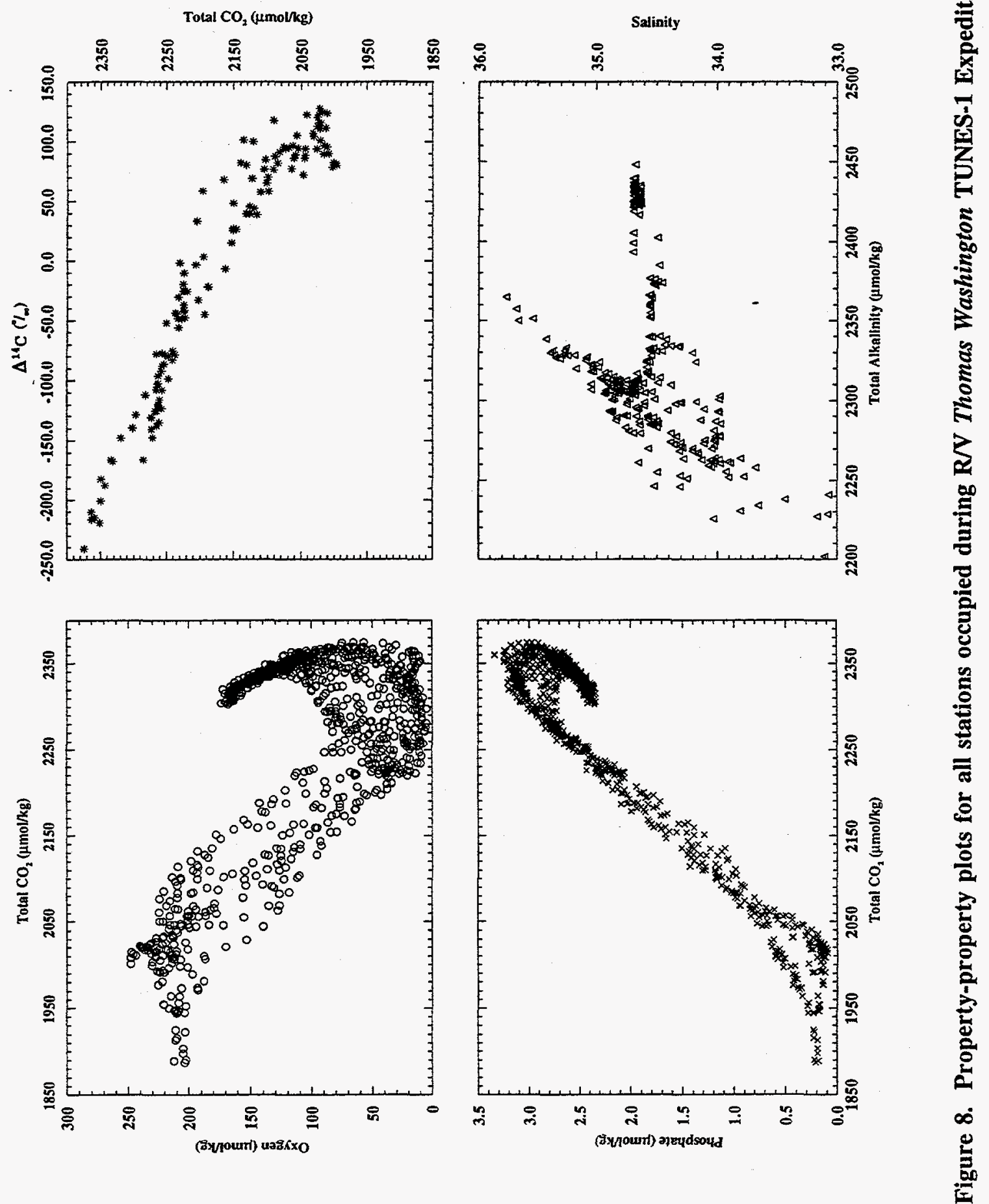


\section{HOW TO OBTAIN THE DATA AND DOCUMENTATION}

This database is available on request in machine-readable form, without charge, from CDIAC. CDIAC will also distribute subsets of the database as needed. It can be acquired on 9-track magnetic tape; 8-mm tape; 150-MB, 0.25-in. tape cartridge; MAC- or IBM-formatted floppy diskettes; or from CDIAC's anonymous file transfer protocol (FTP) area via the Internet (see FTP address below). Requests should include any specific media instructions required by the user to access the data (e.g., 1600 or 6250 BPI, labeled or nonlabeled, ASCII or EBCDIC characters, and variable- or fixed-length records; 3.5 - or 5.25-in. floppy diskettes, high or low density; and 8200 or 8500 format, $8-\mathrm{mm}$ tape). Magnetic tape requests not accompanied by specific instructions will be filled on 9-track, 6250-BPI, nonlabeled tapes with ASCII characters. Requests should be addressed to

Carbon Dioxide Information Analysis Center

Oak Ridge National Laboratory

P.O. Box 2008

Oak Ridge, TN 37831-6335

U.S.A.

Telephone: $\quad 423-574-0390$ or $423-574-3645$

Fax: $\quad 423-574-2232$

Electronic mail: cdiac@ornl.gov

The data files can also be acquired from CDIAC's anonymous FTP area via the Internet:

- $\quad$ FTP to cdiac.esd.ornl.gov (128.219.24.36),

- enter "ftp" or "anonymous" as the user ID,

- enter your electronic mail address as the password (e.g.,"alex@alex.esd.ornl.gov"),"

- change to the directory "/pub/ndp062," and

- acquire the files using the FTP "get" or "mget" command.

As an alternative, one can access the following World Wide Web URL http://cdiac.esd.ornl.gov/ftpdir/ftpinst.html

${ }^{1}$ Please enter your correct address. This address is used by CDIAC to inform data recipients of revisions and updates. 


\section{REFERENCES}

Atlas, E. L., S. W. Hager, L. I. Gordon, and P. K. Park. 1971. A Practical Manual for Use of the Technicon® in Seawater Nutrient Analyses; rev. ed. Technical Report 215, Refs. 71-22. Department of Oceanography, Oregon State University, Corvallis.

Bradshaw, A. L., and P. G. Brewer. 1988. High precision measurements of alkalinity and total carbon dioxide in seawater by potentiometric titration. Mar. Chem. 23:69-86.

Bradshaw, A. L., P. G. Brewer, D. Shafer, and R. T. Williams. 1981. Measurements of total carbon dioxide and alkalinity by potentiometric titration in the GEOSECS program. Earth Planet. Sci. Lett. 55:99-115.

Brewer, P. G., A. L. Bradshaw, and R. T. Williams. 1986. Measurements of total carbon dioxide and alkalinity in the North Atlantic Ocean in 1981. pp. 358-81. In: D. Reichle (ed.), The Global Carbon Cycle: Analysis of the Natural Cycle and Implications of Anthropogenic Alterations for the Next Century. Springer-Verlag, New York.

Brewer, P. G., C. Goyet, and D. Dyrssen. 1989. Carbon dioxide transport by ocean currents at $25^{\circ}$ N latitude in the Atlantic Ocean. Science 246:477-79.

Broecker, W. S., and E. A. Olson. 1961. Lamont radiocarbon measurements VIII: Radiocarbon 3:176-274.

Bryden, H. L., and M. M. Hall. 1980. Heat transport by ocean currents across $25^{\circ} \mathrm{N}$ latitude in the North Atlantic Ocean. Science 207:884.

Bullister, J. L., and R. F. Weiss. 1988. Determination of $\mathrm{CCl}_{3} \mathrm{~F}$ and $\mathrm{CCl}_{2} \mathrm{~F}_{2}$ in seawater and air. Deep-Sea Res. 35:839-53.

Carpenter, J. H. 1965. The Chesapeake Bay Institute technique for the Winkler dissolved oxygen method. Limnol. \& Oceanogr. 10:141-43.

Cohen, G. J., D. L. Hutton, K. F. Von Reden, E. A. Osborne, A. R. Gagnon, A. P. McNichol, and G. A. Jones. 1994. Automated sample processing at the National Ocean Sciences AMS Facility. Nucl. Instrum. Methods Phys. Res. Sect. B-Beam Interactions with Materials and Atoms 92(1-4), 129-38.

Culberson, C. H., and R. T. Williams. 1991. A comparison of methods for the determination of dissolved oxygen in seawater. Report No. WHPO 91-2. WOCE Hydrographic Programme Office, Woods Hole Oceanographic Institution, Woods Hole, Mass.

Dyrssen, D., 1965. A gran titration of seawater on board Sagitta. Acta Chem. Scand. 19:225-46.

Fonselius, S., and H. G. Östlund. 1959. Natural radiocarbon measurements on surface water from the North Atlantic and the Arctic Sea. Tellus Ser. A 11:77-82. 
Gagnon, A. R., and G. A. Jones. 1993. AMS-graphite target production methods at the Woods Hole Oceanographic Institution during 1986-1991. Radiocarbon 35:2.

Goyet, C., and S. D. Hacker. 1992. Procedure for calibration of a coulometric system used for total inorganic carbon measurements of seawater. Mar. Chem. 38:37-51.

Guenther, P. R., C. D. Keeling, and G. Emanuele III. 1994. Oceanic $\mathrm{CO}_{2}$ Measurements for the WOCE Hydrographic Survey in the Pacific Ocean, 1990-1991: Shore Based Analyses. SIO Reference Series, Ref. No. 94-28. University of California, San Diego.

Johnson, K. M., A. E. King, and J. M. Sieburth. 1985. Coulometric $\mathrm{TCO}_{2}$ analyses for marine studies: An introduction. Mar. Chem. 16:61-82.

Johnson, K. M., J. M. Sieburth, P. J. Williams, and L. Brandstrom. 1987. Coulometric total carbon dioxide analysis for marine studies: Automation and calibration. Mar. Chem. 21:117-33.

Key, R. M. 1991. Radiocarbon. In: WOCE Hydrographic Operations and Methods Manual, Report No. WHPO 91-68. WOCE Hydrographic Programme Office. Woods Hole Oceanographic Institution, Woods Hole, Mass.

Key, R. M. 1996a. P17C TUNES-1 final report for large volume samples. Ocean Tracer Laboratory Technical Report No. 96-2. Princeton University, Princeton, N.J.

Key, R. M. 1996b. P17C TUNES-1 final report for AMS ${ }^{14} \mathrm{C}$ samples. Ocean Tracer Laboratory Technical Report No. 96-3. Princeton University, Princeton, N.J.

McNichol, A. P., and G. A. Jones. 1991. Measuring ${ }^{14} \mathrm{C}$ in seawater by accelerator mass spectrometry. In: WOCE Hydrographic Operations and Methods Manual, Report No. WHPO 91-68. WOCE Hydrographic Programme Office, Woods Hole Oceanographic Institution, Woods Hole, Mass.,

Roemmich, D., and C. Wunsch. 1985. Two transatlantic sections: Meridional circulation and heat flux in the subtropical North Atlantic Ocean. Deep-Sea Res. 32:619-64.

Stuiver, M. 1980. Workshop on ${ }^{14} \mathrm{C}$ reporting. Radiocarbon 22:964-66.

Stuiver, M., and S. W. Robinson. 1974. University of Washington GEOSECS North Atlantic carbon-14 results. Earth Planet. Sci. Lett. 23:87-90.

Stuiver, M., S. W. Robinson, H. G. Östlund, and H. G. Dorsey. 1974. Carbon-14 calibration between the University of Washington and the University of Miami GEOSECS laboratories. Earth Planet. Sci. Lett. 23:65-68.

UNESCO. 1981. Background Papers and Supporting Data on the Practical Salinity Scale, 1978. UNESCO Technical Papers in Marine Science, No. 37. 144 pp.

Williams, P. J. 1990. Oceans, Carbon, and Climate Change. Scientific Committee on Oceanic Research (SCOR), Halifax, Canada. 
PART 2:

CONTENT AND FORMAT OF DATA FILES 


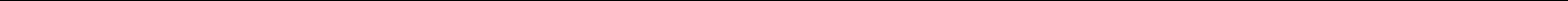




\section{FILE DESCRIPTIONS}

This section describes the content and format of each of the five files that comprise this NDP (Table 3). Because CDIAC distributes the data set in several ways (e.g., via anonymous FTP, on floppy diskette, and on 9-track magnetic tape), each of the five files is referenced by both an ASCII file name, which is given in lowercase, boldfaced type (e.g., ndp062.doc), and a file number. The remainder of this section describes (or lists, where appropriate) the contents of each file. The files are discussed in the order in which they appear on the magnetic tape.

Table 3. Content, size, and format of data files

File number, name, and description
Logical records
File size

in bytes

\section{Block}

size

Record

length

1. ndp062.doc:

1,654

129,660

8,000

80

a detailed description

of the cruise network, the two FORTRAN 77 dataretrieval routines, and the two oceanographic data files

2. stainv.for:

a FORTRAN 77 data-retrieval routine to read and print tun1sta.inv (File 4)

3. tun1dat.for: a FORTRAN 77 data-retrieval routine to read and print tun1.dat (File 5)

4. tun1sta.inv:

a listing of the station locations, sampling dates, and corrected sounding bottom depths for each of all stations

5. tun1.dat:

hydrographic, carbon dioxide, and chemical data from all stations 


\section{ndp062.doc (File 1)}

This file contains a detailed description of the data set, the two FORTRAN 77 data-retrieval routines, and the two oceanographic data files. It exists primarily for the benefit of individuals who acquire this database as machine-readable data files from CDIAC.

\section{stainv.for (File 2)}

This file contains a FORTRAN 77 data-retrieval routine to read and print tun1sta.inv (File 4). The following is a listing of this program. For additional information regarding variable definitions, variable length, variable type, units, and codes, please see the description for tun1sta.inv.

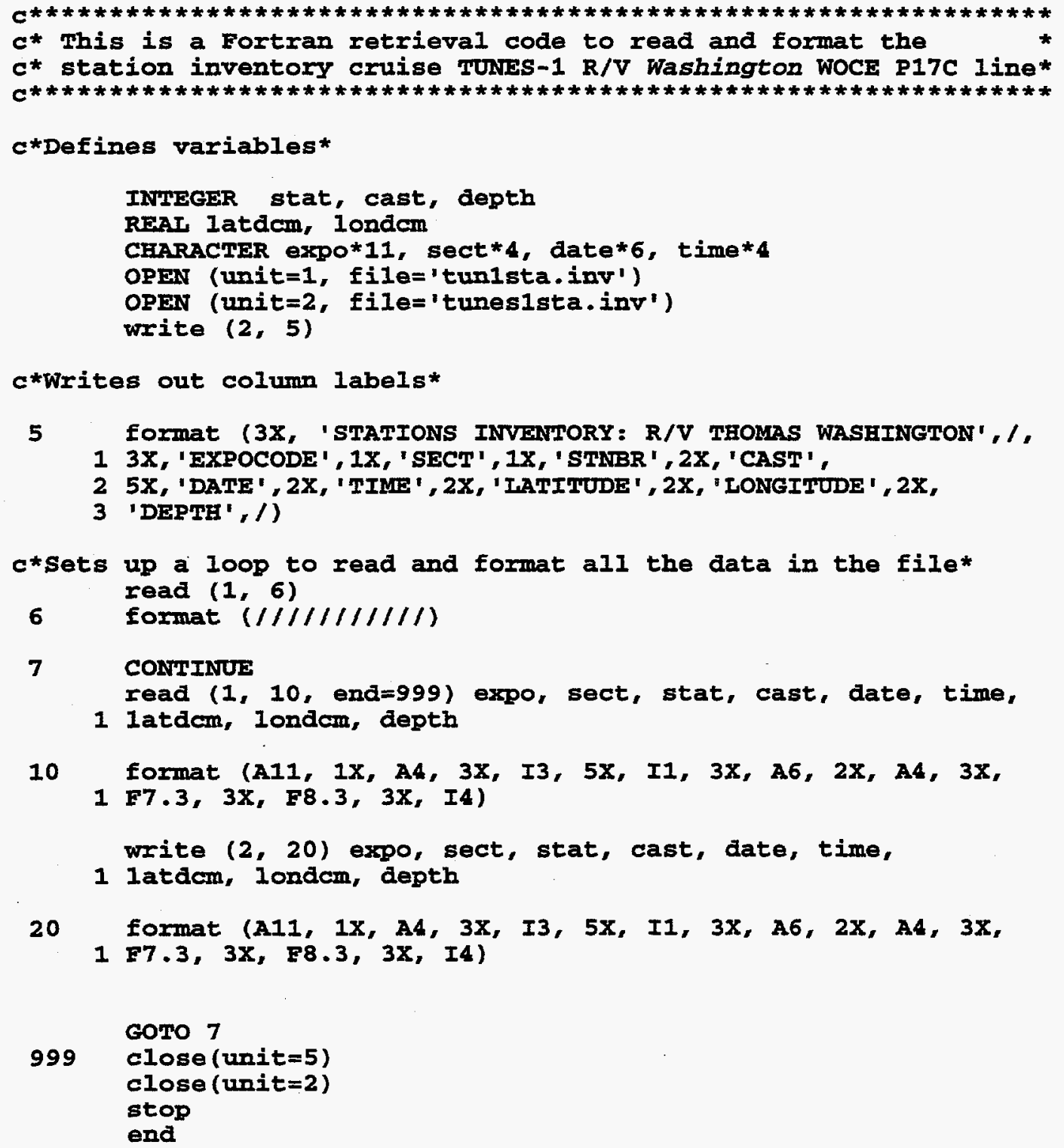




\section{tun1dat.for (File 3)}

This file contains a FORTRAN 77 data-retrieval routine to read and print tun1.dat (File 5). The following is a listing of this program. For additional information regarding variable definitions, variable length, variable type, units, and codes, please see the description for tun1.dat.

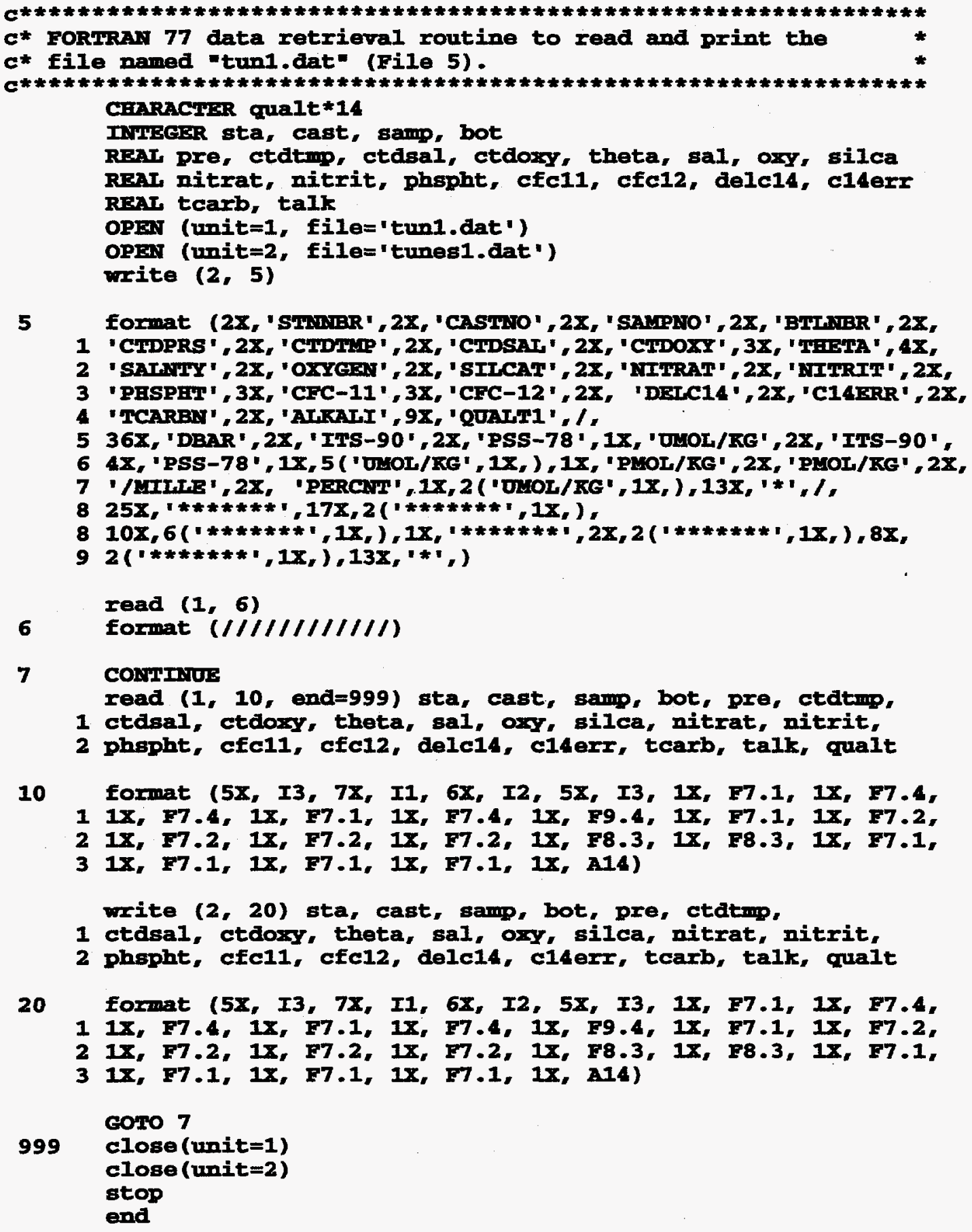

5 format (2X, 'STHETR', 2X, 'CASTHO', 2X, 'SAMPNO', 2X, 'BILNBR', 2X,

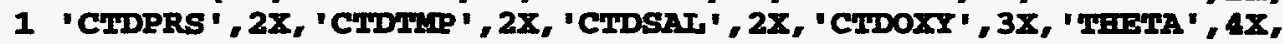

2 'SATAHY', 2X, "OXYGEN" , 2X, "SIICAT", 2X, "NITRAT', 2X, 'NIHRIT', 2X,

3 'PESPEY' ' 3X, 'CFC-11', 3x, 'CFC-12', 2X, 'DELC14', 2X, 'C14ERR', 2X,

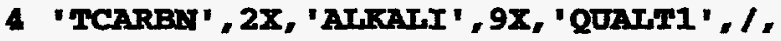

5 36X, 'DBAR', 2X, 'IMS-90', 2X, 'PSS-78 ', 1X, ' ULOL/KG', 2X, 'ITS-90',

$64 \mathrm{X}$, 'PSS-78', 1X, 5 ( 'ULOL/KG', 1X, ), 1X, 'PWOL/KG', 2X, ' PWOL/KG' , 2X,

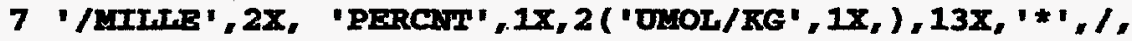

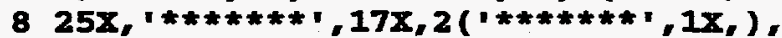

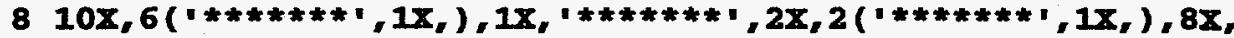

$\left.92\left(1 * * * * * \hbar * 1,1 x_{r}\right), 13 x_{,}, *,\right)$

6 format $(/ / / / / / / / / / / / / 1)$

7 CONHINUE

read (1, 10, end=999) sta, cast, samp, bot, pre, ctdtum,

1 ctdsal, ctdoxy, theta, sal, oxy, silca, nitrat, nitrit,

2 phopht, cfc11, cfc12, delc14, c14err, tcarb, talk, qualt

format (5X, I3, 7X, I1, 6x, I2, 5X, I3, 1X, F7.1, 1X, F7.4,

1 1X, F7.4, 1X, F7.1, 1X, F7.4, 1X, F9.4, 1X, F7.1, 1X, F7.2,

2 1X, F7.2, 1X, F7.2, 1X, F7.2, 1X, F8.3, 1X, F8.3, 1X, F7.1,

3 1X, F7.1, 1X, F7.1, 1X, F7.1, 1X, A14)

write $(2,20)$ sta, cast, samp, bot, pre, ctdtmp,

1 ctdsal, ctdoxy, theta, sal, oxy, silca, nitrat, nitrit,

2 phspht, cfc11, cfe12, delc14, c14err, tcarb, talk, qualt

20 format (5X, I3, 7X, I1, 6x, I2, 5x, I3, 1X, F7.1, 1X, F7.4, 1 1X, F7.4, 1X, F7.1, 1X, F7.4, 1X, F9.4, 1X, F7.1, 1X, F7.2, 2 1X, F7.2, 1X, F7.2, 1X, F7.2, 1X, F8.3, 1X, F8.3, 1X, F7.1,

3 1X, F7.1, 1X, F7.1, 1X, F7.1, 1X, 214)

coro 7

999 close (unit=1)

close (unit=2)

stop

end 


\section{tun1sta.inv (File 4)}

This file provides station inventory information for each of the 123 stations occupied during the R/V Thomas Washington TUNES-1 Expedition. Each record of the file contains an expocode, section number, station number, cast number, sampling date, sampling time, latitude, longitude, and sounding depth. The file is sorted by station number and can be read by using the following FORTRAN 77 code (contained in stainv.for, File 2):

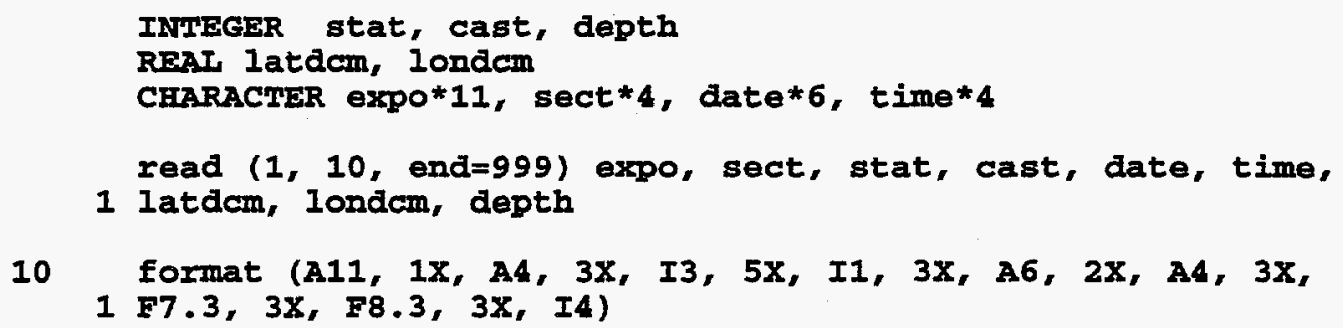

Stated in tabular form, the contents include the following:

\begin{tabular}{llccc} 
Variable & $\begin{array}{c}\text { Variable } \\
\text { type }\end{array}$ & $\begin{array}{c}\text { Variable } \\
\text { width }\end{array}$ & $\begin{array}{c}\text { Starting } \\
\text { column }\end{array}$ & $\begin{array}{c}\text { Ending } \\
\text { column }\end{array}$ \\
\hline expo & Character & 11 & 1 & 11 \\
sect & Character & 4 & 13 & 16 \\
stat & Numeric & 3 & 20 & 22 \\
cast & Numeric & 1 & 28 & 28 \\
date & Character & 6 & 32 & 37 \\
time & Character & 4 & 40 & 43 \\
latdcm & Numeric & 7 & 47 & 53 \\
londcm & Numeric & 8 & 57 & 64 \\
depth & Numeric & 4 & 68 & 71 \\
\end{tabular}

where

expo is the expocode of the cruise;

sect is the WOCE section number;

stat is the station number (values range from 1 to 123 );

date is the sampling date (month/day/year);

time is the sampling time at the bottom (Greenwich mean time); 
latdem is the latitude of the station (in decimal degrees, negative values indicate the Southern Hemisphere);

Iondem is the longitude of the station (in decimal degrees, negative values indicate the Western Hemisphere); and

depth is the corrected sounding bottom depth of the station (meters).

\section{tun1.dat (File 5)}

This file provides hydrographic, $\mathrm{CO}_{2}$, and chemical data for the 123 stations occupied during the R/V Thomas Washington TUNES-1 Expedition. Each record contains a station number, cast number, sample number, bottle number, CTD pressure, CTD temperature, CTD salinity, CTD oxygen, potential temperature, bottle salinity, bottle oxygen, silicate, nitrate, nitrite, phosphate, CFC-11, CFC-12, $\Delta^{14} \mathrm{C},{ }^{14} \mathrm{C}$ error, $\mathrm{TCO}_{2}, \mathrm{TALK}$, and data-quality flags. The file is sorted by station number and pressure and can be read by using the following FORTRAN 77 code (contained in tun1dat.for, File 3):

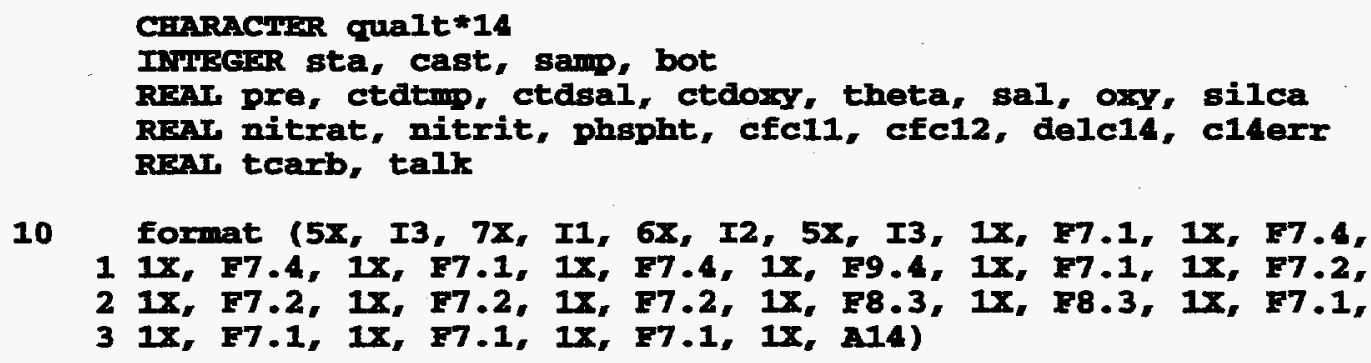

Stated in tabular form, the contents include the following:

\begin{tabular}{llccc}
\hline Variable & $\begin{array}{c}\text { Variable } \\
\text { type }\end{array}$ & $\begin{array}{c}\text { Variable } \\
\text { width }\end{array}$ & $\begin{array}{c}\text { Starting } \\
\text { column }\end{array}$ & $\begin{array}{c}\text { Ending } \\
\text { column }\end{array}$ \\
\hline sta & Numeric & 3 & 6 & 8 \\
cast & Numeric & 1 & 16 & 16 \\
samp & Numeric & 2 & 23 & 24 \\
bot & Numeric & 2 & 31 & 32 \\
pre & Numeric & 6 & 35 & 40 \\
ctdtmp & Numeric & 7 & 42 & 48 \\
ctdsal & Numeric & 7 & 50 & 56 \\
ctdoxy & Numeric & 7 & 58 & 64 \\
theta & Numeric & 7 & 66 & 72 \\
sal & Numeric & 9 & 74 & 82 \\
oxy & Numeric & 7 & 84 & 90 \\
silca & Numeric & 7 & 92 & 98
\end{tabular}




$\begin{array}{lllll}\text { nitrat } & \text { Numeric } & 7 & 100 & 106 \\ \text { nitrit } & \text { Numeric } & 7 & 108 & 114 \\ \text { phspht } & \text { Numeric } & 7 & 116 & 122 \\ \text { cfc11 } & \text { Numeric } & 8 & 124 & 131 \\ \text { cfc12 } & \text { Numeric } & 8 & 133 & 140 \\ \text { delc14 } & \text { Numeric } & 7 & 142 & 148 \\ \text { c14err } & \text { Numeric } & 7 & 150 & 156 \\ \text { tcarb } & \text { Numeric } & 7 & 158 & 164 \\ \text { talk } & \text { Numeric } & 7 & 166 & 172 \\ \text { qualt } & \text { Character } & 14 & 174 & 187\end{array}$

where

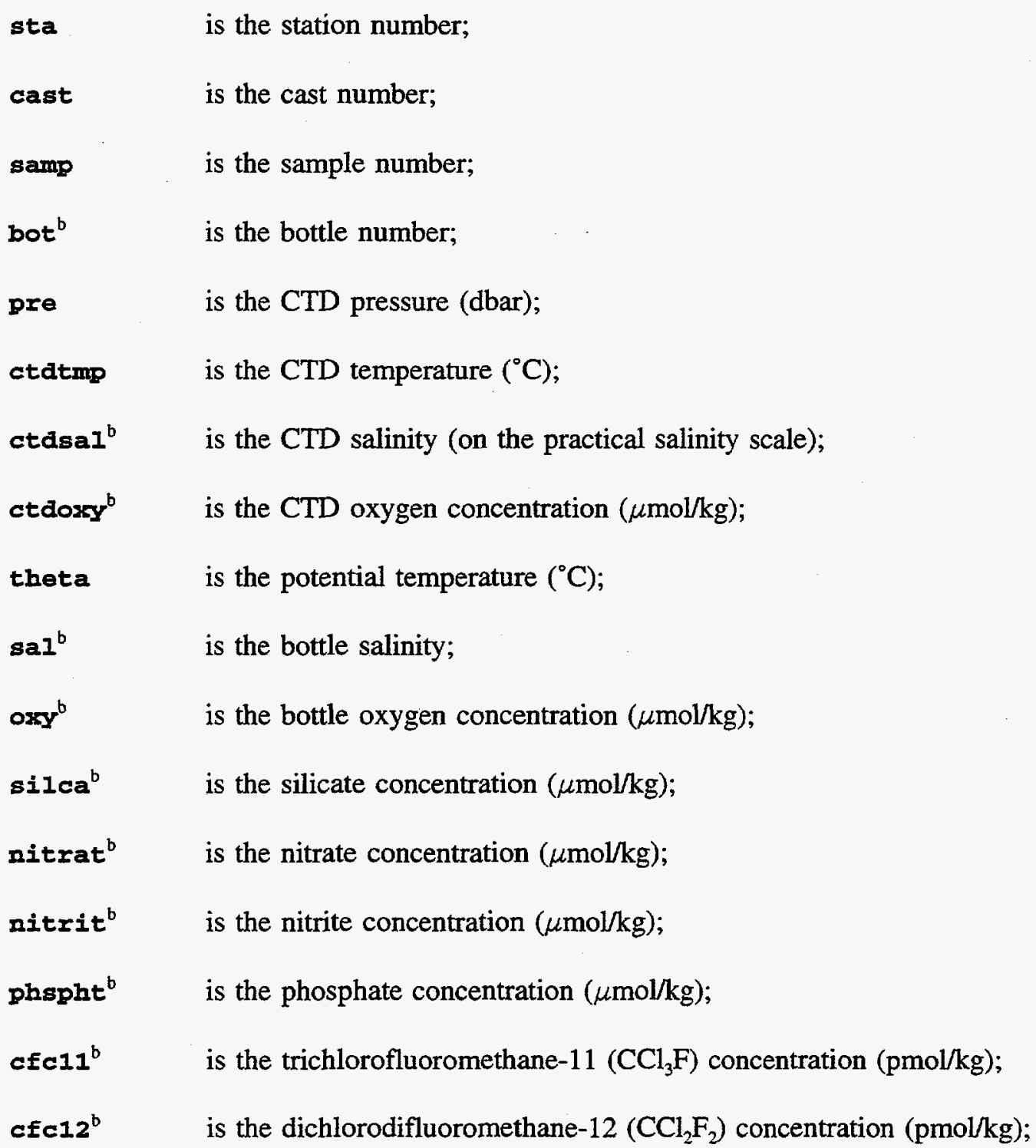


delc14 ${ }^{\mathrm{b}} \quad$ is the radiocarbon $\Delta^{14} \mathrm{C}$ (per mille);

c14err is the error of $\Delta^{14} \mathrm{C}$ (percent);

tcarb $^{\mathrm{b}} \quad$ is the total carbon dioxide concentration $(\mu \mathrm{mol} / \mathrm{kg})$;

$\operatorname{talk}^{\mathrm{b}} \quad$ is the total alkalinity $(\mu \mathrm{mol} / \mathrm{kg})$; and

qualt is a 14-digit character variable that contains data-quality flag codes for parameters underlined with asterisks (*) in the output file.

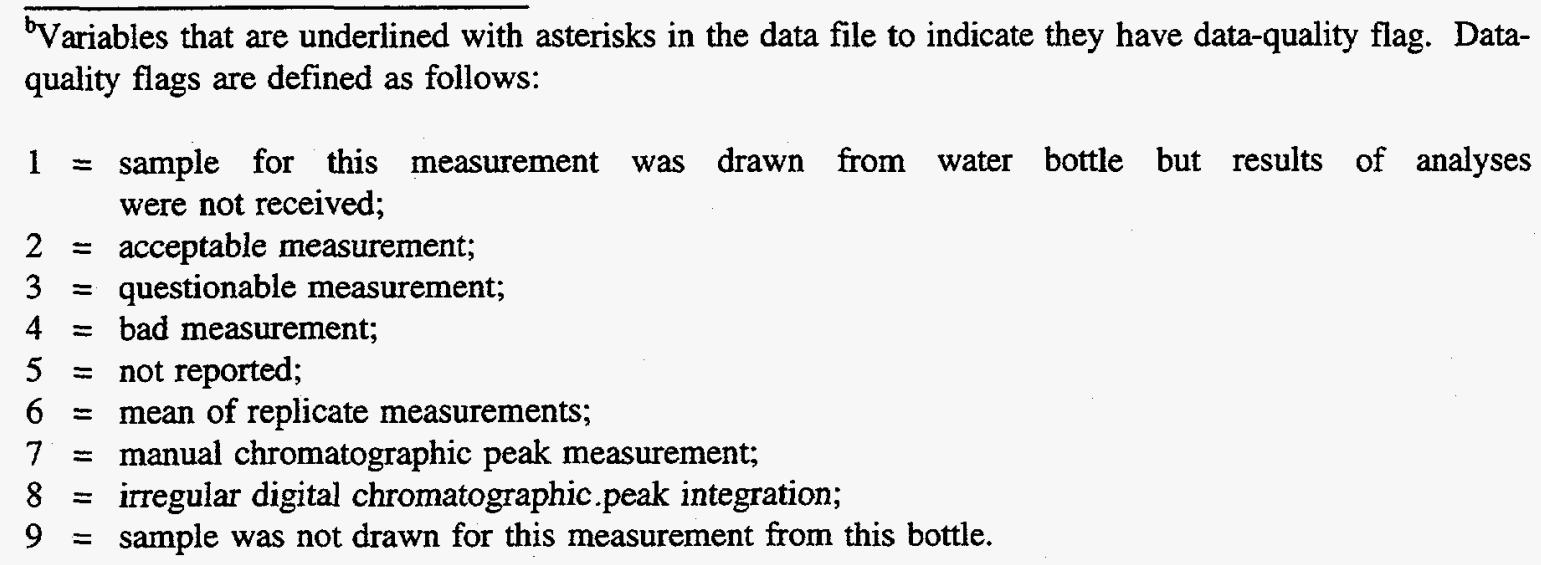




\section{VERIFICATION OF DATA TRANSPORT}

The data files contained in this NDP can be read by using the FORTRAN 77 data-retrieval programs provided. Users should visually examine each data file to verify that the data were correctly transported to their systems. To facilitate the visual inspection process, partial listings of each data file are provided in Tables 4 and 5. Each of these tables contains the first five and last five lines of a data file.

Table 4. Partial listing of "tun1sta.inv" (File 4)

First five lines of the file:

31 WTHUNES/1 P17C 31 WTITHES/1 P17C

31 WTIUTES/1 P17C

31 WTIUUES/1 P17C

31 WIIUUTS/1 P17C
11

2

3

4

5

\section{1 \\ 1}

1

1

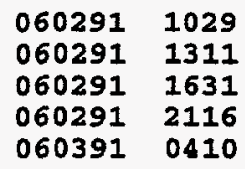

0602911029

$060291 \quad 1311$

$060291 \quad 1631$

0602912116

0603910410

36.172

36.100

35.980

35.790

35.548
$-121.737$

$-121.833$

$-121.993$

$-122.278$

$-122.863$
552

908

1408

2308

3262

Last five lines of the file:

\begin{tabular}{|c|c|}
\hline 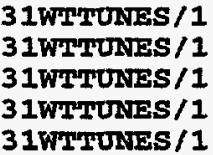 & $\begin{array}{l}\text { P17C } \\
\text { P17C } \\
\text { P17C } \\
\text { P17C } \\
\text { P17C }\end{array}$ \\
\hline
\end{tabular}

$-3.993$

$-4.467$

$-5.008$

$-5.502$

$-5.978$

$-135.000$

$-135.000$

$-135.008$

$-135.002$

$-135.003$ 
First five lines of the file:

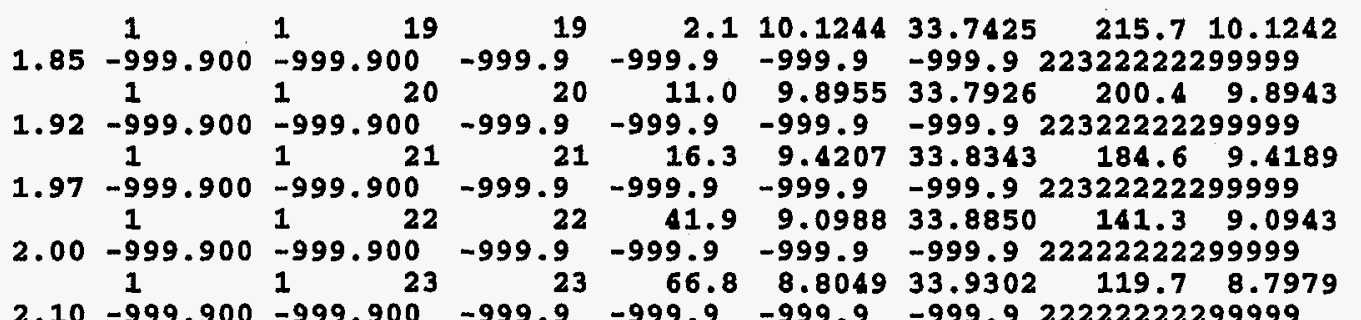

33.7326

$216.7 \quad 27.97$

22.99

0.22

33.7902

$190.0 \quad 28.66$

24.06

0.20

33.8177

$172.8 \quad 30.03$

24.74

0.18

33.8706

145.5

31.69

25.82

0.19

$\begin{array}{llllllll}2.10 & -999.900 & -999.900 & -999.9 & -999.9 & -999.9 & -999.9 & 22222222299999\end{array}$

Last five lines of the file:

$\begin{array}{lllll}34.6867 & 156.9 & 141.57 & 35.71 & 0.00 \\ 34.6896 & 160.3 & 141.38 & 35.35 & 0.00 \\ 34.6928 & 165.5 & 138.99 & 35.14 & 0.00 \\ 34.6950 & 171.6 & 135.67 & 34.68 & 0.00 \\ 34.6960 & 173.1 & 134.38 & 34.63 & 0.00\end{array}$


APPENDIX:

STATION INVENTORY 


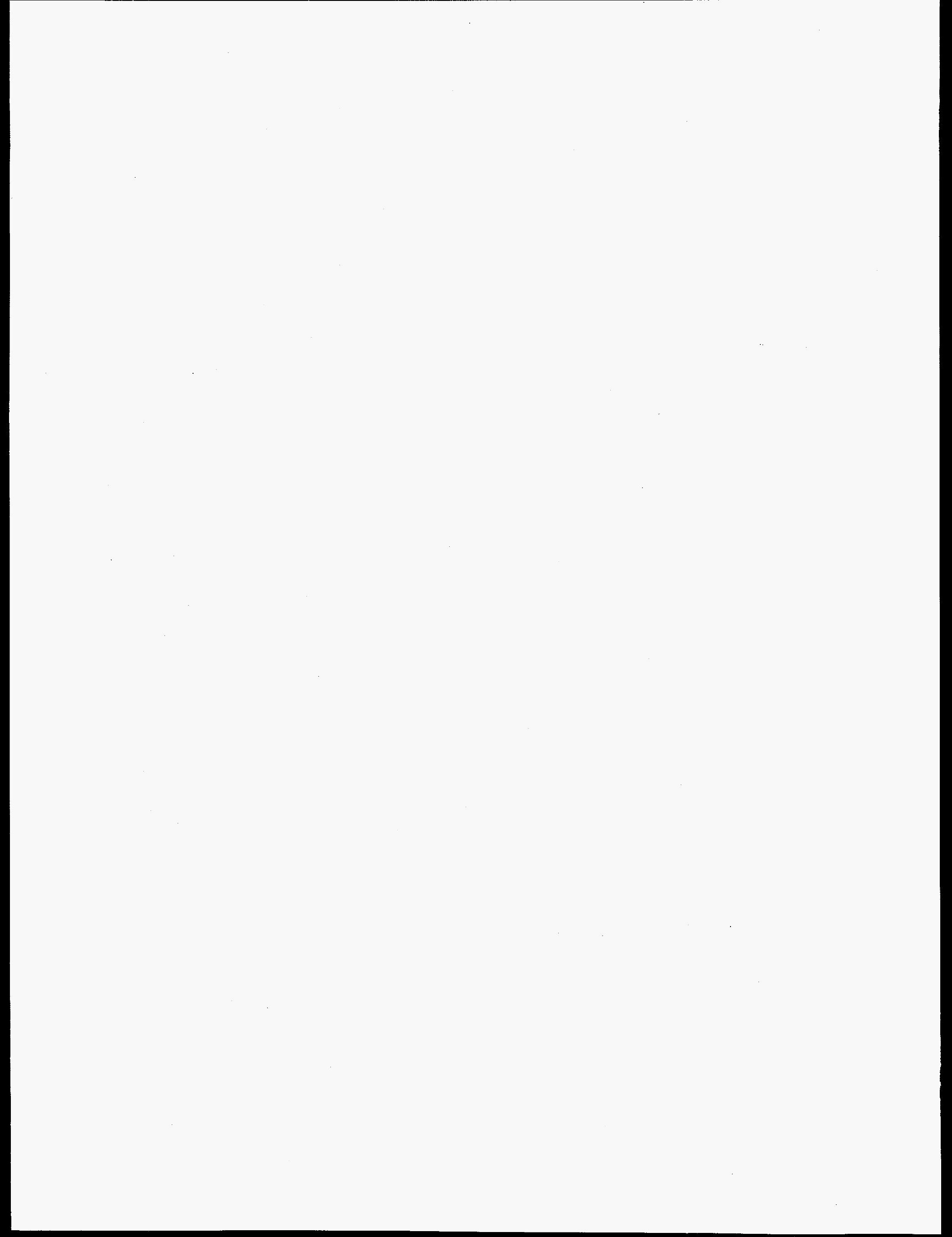




\section{APPENDIX: STATION INVENTORY}

This appendix lists station inventory information for the 123 sites occupied during the R/V Thomas Washington TUNES-1 Expedition in the South Pacific Ocean. The meanings of the column headings in Table A.1 are as follows.

EXPOCODE is the expocode of the cruise;

SECT is the WOCE section number;

STNBR is the station number;

CAST is the cast number;

DATE is the sampling date (month/day/year);

TIME is the sampling time at the bottom (Greenwich mean time);

LATITUDE is the latitude of the station (in decimal degrees). Stations in the Southern Hemisphere have negative latitudes;

LONGITUDE is the longitude of the station (in decimal degrees). Stations in the Western Hemisphere have negative longitudes; and

DEPTH is the corrected sounding bottom depth of each station (meters). 


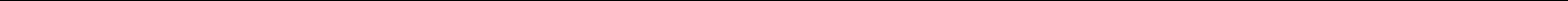


Table A.1. Station inventory information for the 123 sites occupied during R/V Thomas Washington TUNES-1 Expedition

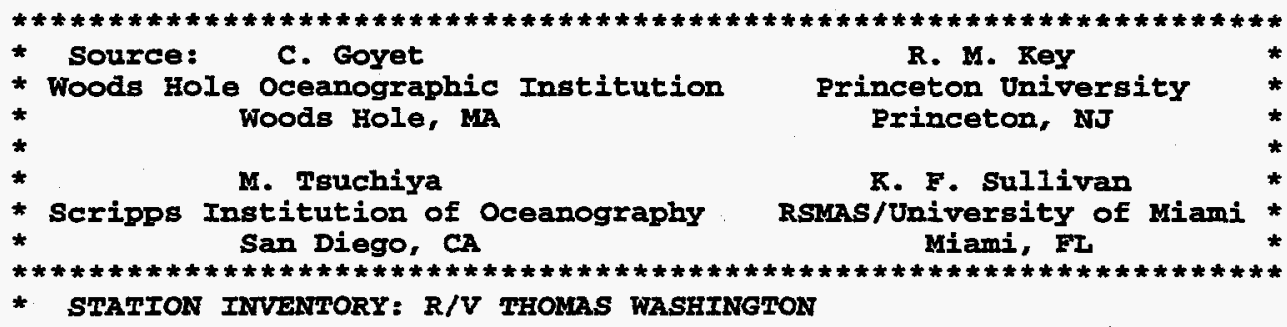

* EXPOCODE SECT STMBR CAST DATE TIME ILATITUDE IONGITUDE DEPTH

31WTPUNES/1 P17C 31WTIUNES/1 P17C 31 WTPUNES/I P17C 31WTTUNES/ 1 P17C 31WTrUNES/ 1 P17C 31WTTUNES/ 1 P17C 31WTrUNES/1 P17C 31 WTPUNES/1 P17C 31WTIUINES/I P17C 31WHTIUTS/1 P17C 31WTTUNES/1 P17C 31WTHUNES/1 P17C 31WTHUNES/1 P17C 31 WTHUNES/1 P17C 31WHTUNES/1 P17C 31WTHUNES/1 P17C 31WTrJUNES/1 P17C 31WTIONES/1 P17C 31WTHULES/1 P17C 31WTHUNES/1 P17C 31WHIUNES/ 1 P17C 31WTHONES/1 P17C 31WTHUNES/ 1 P17C 31WTIOUES/ 1 P17C 31 WTHOUNES/1 P17C 31 WITHONES/1 P17C 31WTPUNTES/1 P17C 31WHTUNES/1 P17C 31WTPUNES/1 P17C 31WTrUNES/ 1 P17C 31WTTUNES/ 1 P17C 31WTHUNES/1 P17C 31WTIUNES/1 P17C 31WTIUNES/1 P17C 31 WTHOUES/ 1 P17C 31WTHUNES/ 1 P17C 31WTIUNES/ 1 P17C 31WTTUNES/ 1 P17C 31WTTUNES/1 P17C 31 WTPUNES/ 1 R17C 31WPIUNES/1 P17C 31WमrITNES/1 P17C 31WTTUNES/1 P17C 31 WTIUNES/1 P17C 31 WTrUUES/1 P17C 31WTrUNES/I P17C 31WTrUNES/1 P17C 31 WTHUNES/1 P17C 31WTTONES/1 R17C 31WTHUNES/1 P17C 31WTrUNES/1 P17C 31WTMUNES/1 P17C

$$
\begin{aligned}
& 1 \\
& 2 \\
& 3 \\
& 4 \\
& 5 \\
& 6 \\
& 7 \\
& 8 \\
& 9 \\
& 10 \\
& 11 \\
& 12 \\
& 13 \\
& 14 \\
& 15 \\
& 16 \\
& 17 \\
& 18 \\
& 19 \\
& 20 \\
& 21 \\
& 22 \\
& 23 \\
& 24 \\
& 25 \\
& 26 \\
& 27 \\
& 28 \\
& 29 \\
& 30 \\
& 31 \\
& 32 \\
& 33 \\
& 34 \\
& 35 \\
& 36 \\
& 37 \\
& 38 \\
& 39 \\
& 40 \\
& 41 \\
& 42 \\
& 43 \\
& 44 \\
& 45 \\
& 46 \\
& 47 \\
& 48 \\
& 49 \\
& 50 \\
& 51 \\
& 52 \\
&
\end{aligned}
$$

$\begin{array}{llr}36.172 & -121.737 & 552 \\ 36.100 & -121.833 & 908 \\ 35.980 & -121.993 & 1408 \\ 35.790 & -122.278 & 2308 \\ 35.548 & -122.863 & 3262 \\ 35.298 & -123.433 & 4005 \\ 35.075 & -124.017 & 4160 \\ 34.817 & -124.582 & 4343 \\ 34.582 & -125.157 & 4519 \\ 34.582 & -126.400 & 4682 \\ 34.577 & -127.635 & 4765 \\ 34.583 & -128.847 & 4887 \\ 34.585 & -130.087 & 4338 \\ 34.585 & -131.320 & 5133 \\ 34.588 & -132.442 & 5091 \\ 34.583 & -133.770 & 4323 \\ 34.598 & -134.963 & 5141 \\ 34.067 & -135.000 & 5097 \\ 33.567 & -135.002 & 5033 \\ 33.065 & -134.997 & 4763 \\ 32.597 & -135.000 & 4161 \\ 32.035 & -135.002 & 4943 \\ 31.532 & -135.002 & 4527 \\ 31.018 & -135.000 & 4553 \\ 30.518 & -135.000 & 4567 \\ 30.033 & -134.952 & 5090 \\ 29.508 & -135.002 & 4478 \\ 28.997 & -134.998 & 4511 \\ 28.498 & -134.997 & 3579 \\ 28.005 & -135.002 & 4197 \\ 27.510 & -135.002 & 4477 \\ 27.000 & -134.998 & 4120 \\ 26.502 & -135.000 & 4297 \\ 26.040 & -134.970 & 4573 \\ 25.498 & -134.997 & 4547 \\ 25.002 & -135.000 & 4578 \\ 24.502 & -135.005 & 4545 \\ 23.998 & -135.000 & 4849 \\ 23.503 & -135.005 & 4184 \\ 23.000 & -135.000 & 5145 \\ 22.498 & -135.002 & 5147 \\ 22.037 & -134.997 & 5245 \\ 21.525 & -135.002 & 5211 \\ 21.008 & -135.000 & 5252 \\ 20.497 & -134.998 & 5244 \\ 19.982 & -135.017 & 5257 \\ 19.500 & -135.000 & 5274 \\ 18.998 & -135.000 & 5199 \\ 18.498 & -134.998 & 5200 \\ 18.000 & -135.005 & 5166 \\ 17.500 & -134.997 & 4968 \\ 17.000 & -135.000 & 5281\end{array}$


Table A.1 (continued)

31WTIUNES/1 P17C 31WTHUNES/1 P17C 31WTTUNES/1 P17C 31WTTUNES/1 P17C 31WTrUNES/1 P17C 31WTPUNES/1 P17C 31WTTUNES/1 P17C 31WTHUNES/1 R17C 31WTrtros/1 P17C 31WTTUNES/1 P17C 31WTTUNES/1 P17C 31WTHUNES/1 P17C 31WTPUNES/1 P17C 31WTTUNES/1 P17C 31WTTUNES/I P17C 31WTPUNES/1 P17C 31WTrUNES/1 P17C 31WTTUNES/1 P17C 31WTTUNES/ 1 P17C 31WTTUNTS / 1 P17C 31WTTUNES/1 P17C 31WTrUNES/ 1 P17C 31WTTUNES/1 P17C 31WTHUNES/1 P17C 31WTTUNES/1 P17C 31WTTUNES/1 P17C 31WTPUNES/1 P17C 31WTIUNES/I P17C 31WTrUNES/ 1 P17C 31WTTUNES/1 P17C 31WTTUNES/1 P17C 31WTHUNES/1 P17C 31 WTPUNES / I P17C 31WTTUNES/1 P17C 31 WTPUNES/ 1 P17C 31WTIUNES/1 P17C 31WTTUNES/I P17C 31WTTUNES/1 P17C 31WrTUNES/1 P17C 31WTTUNES/1 P17C 31WTTUNES/1 P17C 31WTTUNES/1 P17C 31WTTUNES/1 P17C 31 WTTUNIS/1 P17C 31WTHUNTS/I P17C 31WTrUNES/1 P17C 31WTPUNES/ 1 P17C 31WTHUNES/1 P17C 31WTPUNES/1 P17C 31WTTUNES/1 P17C 31 WTTUNES/1 P17C 31 WTPUNES/1 P17C 3 IWTHUNES/1 P17C 31WTPUNES/1 P17C 31 WTTUNES/1 P17C 31 WTTUNES/1 P17C 31WTrTUNES/1 P17C 31 WTHONES/1 P17C 31 WTHUNES/1 P17C 31WTTUNES/1 P17C 31WTrUNES/1 P17C 31WTMUNES/1 P17C 31WTTUNES/I P17C 31WTTUNES/ 1 P17C 31WTTUNES/1 P17C 31WTPUNES/1 P17C



4832

4715

5001

4906

896

849

4852

4888

909

824

4779

737

631

4586

532

431

366

4411

4574

549

469

378

4284

212

3401

4318

4223

4236

319

4463

4365

4396

4365

4439

4438

395

422

488
459

4614 
Table A.1 (continued)

\begin{tabular}{|c|c|c|c|c|c|c|c|c|}
\hline $\begin{array}{l}31 \text { WTPUNES / } 1 \\
31 \text { WTTUNES / } \\
31 \text { WTTUNES / } \\
31 \text { WTTUNES / } 1 \\
31 \text { WTTUNES / } \\
31 \text { WTTUNES / }\end{array}$ & $\begin{array}{l}\text { P17C } \\
\text { P17C } \\
\text { P17C } \\
\text { P17C } \\
\text { P17C } \\
\text { P17C }\end{array}$ & $\begin{array}{l}118 \\
119 \\
120 \\
121 \\
122 \\
123\end{array}$ & $\begin{array}{l}1 \\
1 \\
1 \\
1 \\
1 \\
1\end{array}$ & $\begin{array}{l}070591 \\
070591 \\
070691 \\
070691 \\
070791 \\
070791\end{array}$ & $\begin{array}{l}1314 \\
1926 \\
0142 \\
0828 \\
0243 \\
0853\end{array}$ & $\begin{array}{l}-3.488 \\
-3.993 \\
-4.467 \\
-5.008 \\
-5.502 \\
-5.978\end{array}$ & $\begin{array}{l}-135.002 \\
-135.000 \\
-135.000 \\
-135.008 \\
-135.002 \\
-135.003\end{array}$ & $\begin{array}{l}4622 \\
4613 \\
4647 \\
4667 \\
4543 \\
4505\end{array}$ \\
\hline
\end{tabular}




\section{INTERNAL DISTRIBUTION}

1. T. A. Boden

2. M.D. Burtis

3. R. M. Cushman

4. S. V. Jennings

5. S. B. Jones

6. D. P. Kaiser

7. P. Kanciruk

8. T. E. Myrick
9. D. E. Shepherd

10. D. S. Shriner

11. L. D. Voorhees

12. Central Research Library

13-16. ESD Library

17-18. Laboratory Records Department

19. Laboratory Records Department ORNL- RC

20. Y-12 Technical Library

\section{EXTERNAL DISTRIBUTION}

21. William E. Asher, University of Washington, Joint Institute for the Study of the Atmosphere and the Ocean, Box 354235, Seattle, WA 98195

22. Jeff Banasek, UIC, Inc., P.O. Box 83, 1225 Channahon Road, Joliet, IL 60434

23. Robert Bidigare, University of Hawaii, Department of Oceanography, 1000 Pope Road, Honolulu, HI 96822

24. Peter G. Brewer, Monterey Bay Aquarium Research Institute, P.O. Box 628, 7700 Sandholt Road, Moss Landing, CA 95039

25. Michelle Broido, Department of Energy, Office of Health and Environmental Research, Environmental Sciences Division, ER-74, 19901 Germantown Road, Germantown, MD 20874

26. O. B. Brown, University of Miami, 4500 Rickenbacker Causeway, Miami, FL 33149

27. L. Brugmann, Stockhom University, Department of Geology and Geochemistry, S-106 91 Stockholm, Sweden

28. Robert H. Byrne, University of South Florida, Department of Marine Science, 140 Seventh Avenue, S Saint Petersburg, FL 33701

29. David W. Chipman, Columbia University, Lamont-Doherty Earth Observatory, Route $9 \mathrm{~W}$, P. O. Box 1000, Palisades, NY 10964

30. E. G. Cumesty, ORNL Site Manager, Department of Energy, Oak Ridge National Laboratory, P.O. Box 2008, Oak Ridge, TN 37831-6269

31. G. Cutter, Old Dominion University, Department of Oceanography, Norfolk, VA 23529 
32. Giovanni Daneri, CEA Universidad del Mar, Dept. de Oceanografia y Biologia Pesquera, Amunaategui 1838, Vina Del Mar, Chile

33. Andrew G. Dickson, Scripps Institute of Oceanography, University of California, San Diego, Marine Physical Laboratory, 9500 Gilman Drive, La Jolla, CA 92093

34. Scott Doney, National Center for Atmospheric Research, Oceanography Section, P.O. Box 3000, Boulder, CO 80307

35. Hugh W. Ducklow, College of William and Mary, Virginia Institute of Marine Sciences, P. O. Box 1346, Gloucester Point, VA 23062

36. Jerry W. Elwood, Department of Energy, Office of Health and Environmental Research, Environmental Sciences Division, ER-74, 19901 Germantown Road, Germantown, MD 20874

37. Gerd Esser, Justus-Liebig-University, Institute for Plant Ecology, Heinrich-Buff-Ring 38, D-35392 Giessen Germany

38. Wanda Ferrell, Department of Energy, Office of Health and Environmental Research, Environmental Sciences Division, ER-74, 19901 Germantown Road, Germantown, MD 20874

39. Richard H. Gammon, University of Washington, Chemistry Department, Box 351700 , Seattle, WA 98195

40. Jean-Pierre Gattuso, Observatoire Oceanologique Europeen, Avenue Saint-Martin, MC-98000, Monaco

41-45. Catherine M. Goyet, Woods Hole Oceanographic Institute, Marine Chemistry and Geochemistry Department, 360 Woods Hole Road, MS \#25, Woods Hole, MA 02543

46. Nicolas Gruber, University of Bern, Physics Institute, Sidlerstrasse 5, 3012 Bern Switzerland

47. Peter Guenther, Geosciences Research Division 0220, University of California, San Diego, 9500 Gilman Drive, La Jolla, CA 92093-0220

48. David O. Hall, University of London, Division of Biosphere Sciences, King's College London, Campden Hill Road, London W8 7AH, United Kingdom

49. Akira Harashima, Japan Environment Agency, Global Environmental Research Division, 16-2 Onogawa, Tsukuba, Ibaraki 305 Japan

50. Mark Hein, Freshwater Biological Laboratory, Helsingoersgade 51, DK-3400 Hilleroed, Denmark 
51. A. Hittelman, WDC-A for Solid Earth Geophysics, NOAA Code E/GC1, 325 Broadway, Boulder, CO 80303

52. H. Hodgson, British Library, Boston Spa, DSC, Special Acquisitions, Wetherby, West Yorkshire, LS23 7BQ, United Kingdom

53. Huasheng Hong, Xiamen University, Environmental Science Research Center, Post Code 361005, Mail Box 1085, Xiamen, Fujian, Peoples Republic China

54. Carroll A. Hood, GCRIO, 2250 Pierce Road, Bay City, MI 48710

55. John C. Houghton, Department of Energy, Office of Health and Environmental Research, Environmental Sciences Division, ER-74, 19901 Germantown Road, Germantown, MD 20874

56. Kenneth M. Johnson, Brookhaven National Laboratory, Oceanographic and Atmospheric Sciences Division, Department of Applied Science, Building 318, Upton, NY 11973

57. Fortunat Joos, University of Bern, Physics Institute, KUP, Sidlerstr. 5, Bern CH-3012 Switzerland

58. David M. Karl, University of Hawaii, Department of Oceanography, 1000 Pope Road, Honolulu, HI 96822

59. Thomas R. Karl, National Climatic Data Center, 151 Patton Avenue, Federal Building, Room 516E, Asheville, NC 28801

60. Stephan Kempe, Schnittspahnstr. 9, D-64287 Darmstadt, Germany

61-65. R. M. Key, Princeton University, Geology Department, Princeton, NJ 08544

66. K.-R. Kim, Seoul National University, Dept. of Oceanology, Seoul 151-7442, Korea

67. Takashi Kimoto, Research Institute of Oceano-Chemistry, Osaka Office, 3-1 Fumahashi-cho, Tennoji-ku, Osaka 543 Japan

68. Bert Klein, University Laval, GIROQ, Pav. Vachon, Quebec, PQ, G1K 7P4, Canada

69. John C. Klink, Miami University, Department of Geography, 217 Shideler Hall, Oxford, OH 45056

70. J. Val Klump, University of Wisconsin, Center for Great Lakes Studies, 600 E. Greenfield Avenue, Milwaukee, WI 53204

71. Mikhail H. Koshlyakov, Shirshov Institute of Oceanography, Russian Academy of Sciences, Moscow, Russia 
72. A. Kozyr, The University of Tennessee, Pellissippi Research Facility, 10521 Research Drive, Suite 100, Knoxville, TN 37923

73. Sydney Levitus, National Ocean Data Center, National Oceanic and Atmospheric Administration, E / OC5, 1315 East West Highway, Room 4362, Silver Spring, MD 20910

74. E. Lewis, Brookhaven National Laboratory, Oceanographic Sciences Division, Upton, NY 11973

75. Peter Lunn, Department of Energy, Office of Health and Environmental Research, Environmental Sciences Division, ER-74, 19901 Germantown Road,Germantown, MD 20874

76. Thomas H. Mace, U.S. Environmental Protection Agency, National Data Processing Division, 79 TW Alexander Drive, Bldg. 4201, MD-34, Durham, NC 27711

77. James J. McCarthy, Harvard University, Museum of Comparative Zoology, 26 Oxford Street, Cambridge, MA 02138

78. Michael C. McCracken, Director, Office of the U.S. Global Change Reserch Program, Code YS-1, 300 E. Street, SW, Washington, DC 20546

79. Nicolas Metzl, Universite Pierre et Marie Curie, Laboratory de Physique et Chimie Marines, T 24-25-Case 134, 4, place Jussieu, 75252 Paris Cedex 05, France

80. Frank J. Millero, University of Miami, RSMAS, 4600 Rickenbacker Causeway Miami, FL 33149

81. L. Mintrop, Institute for Marine Research, Marine Chemistry Department, Duesternbrooker Weg 20, D-214105 Kiel Germany

82. J. W. Morse, Texas A \& M University, Department of Oceanography, College Station, TX 77843

83. R. E. Munn, University of Toronto, Institute for Environmental Studies, Haultain Building, 170 College Street, Toronto, Ontario M5S 1A4, Canada

84. Shohei Murayama, National Institute for Resources and Environment, Environmental Assessment Department, 16-3 Onogawa, Tsukuba, Ibaraki 305 Japan

85. Paulette P. Murphy, National Oceanic and Atmospheric Administration, Pacific Marine Environmental Laboratory, Building 3, 7600 Sand Point Way, NE,Seattle, WA 98115

86. Shuzo Nishioka, National Institute for Environmental Studies, Global Environment Research Division, 16-2 Onogawa, Tsukuba, Ibaraki 305 Japan 
87. Jao Ryoung Oh, Korea Ocean Research and Development Institute, Chemical Oceanography Division, An San P.O. Box 29, Seoul 4325-600 Korea

88. J. Olafsson, Marine Research Institute, P.O. Box 1390, Skulagata 4, 121 Reykjavik Iceland

89. C. Olsen, Office of Health and Environmental Research, Environmental Sciences Division, ER74, Department of Energy, 19901 Germantown Road, Germantown, MD 20874

90. C. Oudot, Centre ORSTOM de Cayenne, B.P. 165-97323, Cayene Cedex, Guyana

91. Bobbi Parra, Department of Energy, Office of Health and Environmental Research, Environmental Sciences Division, ER-74, 19901 Germantown Road, Germantown, MD 20874

92. Ari Patrinos, Department of Energy, Office of Health and Environmental Research, Environmental Sciences Division, ER-74, 19901 Germantown Road, Germantown, MD 20874

93. Tsung-Hung Peng, NOAA/AOML, Ocean Chemistry Division, 4301 Rickenbacker Causeway, Miami, FL 33149

94. B. Preselin, University of California, Department of Biological Sciences, Santa Barbara, CA 93106

95. Paul D. Quay, University of Washington, School of Oceanography, Box 357940, Seattle, WA 98195

96. Roberta Y. Rand, USDA, Global Change Data and Information Management, 10301 Baltimore Boulevard, Beltsville, MD 20705

97. Joachim Ribbe, University of Washington, Joint Institute for the Study of the Atmosphere and Oceans, Box \# 35425, Seattle, WA 98195

98. Michael R. Riches, Department of Energy, Office of Health and Environmental Research, Environmental Sciences Division, ER-74, 19901 Germantown Road, Germantown, MD 20874

99. Marilyn F. Roberts, Pacific Marine Environmental Laboratory, National Oceanic and Atmospheric Administration, 7600 Sand Point Way NE, Seattle, WA 98115

100. Stephany Rubin, Lamont-Doherty Earth Observatory of Columbia University, Palisades, NY 10964

101. C. L. Sabine, Princeton University, Geology Department, Guyot Hall, Princeton, NJ 08544

102. M. M. Sarin, Physical Research Laboratory, Navrangpura, Ahmedabad 380009, India 
103. Jorge L. Sarmiento, Princeton University, Atmospheric and Oceanic Sciences Program, P.O. Box CN710, Sayre Hall, Princeton, NJ 08544

104. Gary S. Sayler, The University of Tennessee, Center for Environmental Biotechnology, 676 Dabney Hall, Knoxville, TN 37996-1605

105. Kiminori Shitashima, Central Research Institute of Electric Power Industry, Marine Science Group, 1646, Abiko, Abiko-city, Chiba, 270-11 Japan

106. Nelson Silva, Universidad Catolica de Valparaiso, Escuela de Ciencias de Mar, Casilla 1020, Valparaiso Chile

107. Michel H. C. Stoll, Netherlands Institute for Sea Research, Dept. MCG, P. O. Box 59, $1790 \mathrm{Ab}$ den Burg-Texel Netherlands

108-112. Kevin F. Sullivan, Rosentiel School of Marine and Atmospheric Research, University of Miami, 4600 Rickenbacker Causeway, Miami, FL, 33149-1098

113. Eric T. Sundquist, U.S. Geological Survey, Quissett Campus, Branch of Atlantic Marine Geology, Woods Hole, MA 02543

114. Stuart C. Sutherland, Columbia University, Lamont-Doherty Earth Observatory, P.O. Box 1000, U.S. Route 9W, Palisades, NY 10964

115. James H. Swift, Scripps Institution of Oceanography, University of California, San Diego Oceanographic Data Facility, 9500 Gilman Drive, La Jolla, CA 92093-0124

116. Taro Takahashi, Columbia University, Lamont-Doherty Earth Observatory, Climate/Environment/ Ocean Division, Rt. 9W, Palisades, NY 10964

117. John A. Taylor, Australian National University, CRES, GPO Box 4, Canberra, ACT 0200 Australia

118. John R. G. Townshend, University of Maryland, Dept. of Geography, 1113 Lefrak Hall College Park, MD 20742

119-123. Mizuki Tsuchiya, Scripps Institution of Oceanography, University of California San Diego, 9500 Gilman Drive, La Jolla, CA 92093-0230

124. J. Tucker, Marine Biological Laboratory, Woods Hole, MA 02543

125. D. Turner, University of Goteborg, Department of Analytical and Marine Chemistry, S-41296 Goteborg, Sweden 
126. Douglas W. R. Wallace, Brookhaven National Laboratory, Oceanographic and Atmosphere Sciences Division, P.O. Box 5000, Upton, NY 11973

127. Carol Watts, National Oceanic and Atmoshperic Administration, Central Library, 1315 East-West Highway, 2nd Floor, SSMC 3, Silver Spring, MD 20910

128. Ferris Webster, University of Delaware, College of Marine Studies, Lewes, DE 19958

129. Ray F. Weiss, Scripps Institute of Oceanography, University of California, Mail Code A-020, Room 2271, Ritter Hall, La Jolla, CA 92093

130. Christopher Winn, Scripps Institution of Oceanography, Marine Physical Laboratory, 9500 Gilman Drive, La Jolla, CA 92093-0230

131. Chi Shing Wong, Government of Canada, Institute of Ocean Sciences, P.O. Box 6000, 9860 West Saanich Road, Sidney, BC V8L 4B2, Canada

132. L. Xu, Xiamen University, Environmental Science Research Center, Xiamen, Fujian, Peoples Republic of China

133. Evgeniy Yakushev, Shirshov Institute of Oceanology, 23 Krasikova, Moscow 117218, Russia

134. Yoshifumi Yosuoka, National Institute for Environmental Studies, Center Global Environment Research, 16-2 Onogawa, Tsukuba, Ibaraki 305 Japan

135. Database Section, National Institute for Environmental Studies, Center for Global Environmental Research, 16-2 Onogawa, Tsukuba, Ibaraki 305, Japan

136. Energy Library (HR-832.2/WAS), Department of Energy, Office of Administration and Management, GA-138 Forrestal Building, Washington, DC 20585

137. Energy Library (HR-832.1/GTN), Department of Energy, Office of Administration and Management, G-034, Washington, DC 20585

138. Office of Assistant Manager for Energy Research and Development, Department of Energy, Oak Ridge Operations, P. O. Box 2001, Oak Ridge, TN 37831-8600

139-140. Office of Scientific and Technical Information, P. O. Box 62, Oak Ridge, TN 37831

141-191. Carbon Dioxide Information Analysis Center, Attn: Timothy Stamm, The University of Tennessee, Pellissippi Research Facility, 10521 Research Drive, Suite 100, Knoxville, TN 37923 